\title{
COMMUNITIES PARTNERING WITH RESEARCHERS: AN EVALUATION OF COALITION FUNCTION IN A COMMUNITY-ENGAGED RESEARCH APPROACH
}

by

\section{BRIANA E. ROCKLER}

B.A., University of Colorado, 2007

\begin{abstract}
A THESIS
submitted in partial fulfillment of the requirements for the degree
\end{abstract}

MASTER OF PUBLIC HEALTH

Department of Human Nutrition

College of Human Ecology

\section{KANSAS STATE UNIVERSITY \\ Manhattan, Kansas}

2015

Approved by:

Major Professor Dr. Sandra B. Procter 


\section{Copyright}

BRIANA E. ROCKLER

2015 


\begin{abstract}
Background. Engaging community has become a fundamental approach to improving health outcomes in resource-limited settings. Community coalitions, comprised of resident activists that mobilize to improve local conditions, are frequently utilized as partners for community-engaged research. However, there is limited research that documents how these partnerships affect the coalitions. The purpose of this study was to evaluate the effects of researcher-coalition collaboration in the pilot year of a four-year intervention program targeting childhood obesity in rural, low-income communities.
\end{abstract}

Methods. Twelve pre-established community coalitions from seven states were selected to partner with academic researchers in a quasi-experimental study, and then assigned to either the control $(n=6)$ or intervention ( $n=6)$ group. Both study arms received funding and access to a menu of evidence-based tools, but the intervention groups were also provided a trained community coach. Member survey data from a Coalition Self-Assessment Survey (CSAS) tool was completed at baseline and at one-year follow-up.

Results. CSAS data were analyzed to identify factors related to coalition function and efficacy, and significant changes in both experimental groups were identified. Change in measures of membership recruitment, coalition capacity and coalition communication were unique to the intervention group. Problems for participation were alleviated significantly on all measures in the control group. Comparison of the study groups at follow-up demonstrated that greater research involvement positively impacted membership recruitment and coalition action plan.

Conclusion. The data suggest that coalitions with a higher degree of partnership interaction may be more successful in addressing problems impacting their communities. 


\section{Table of Contents}

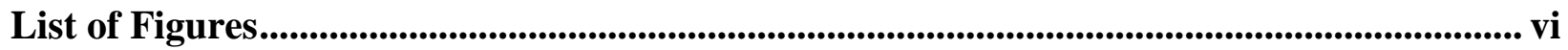

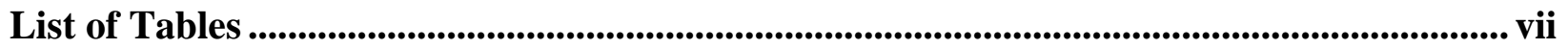

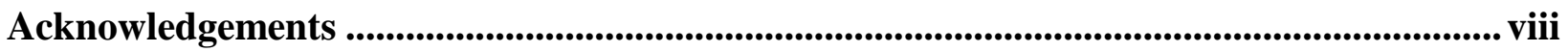

Dedication

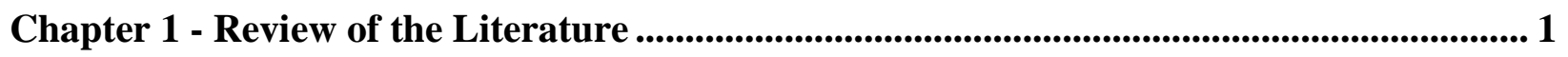

Rural Health in the United States ................................................................................ 2

Community Engagement and Public Health: "Applying what works, and doing what is right

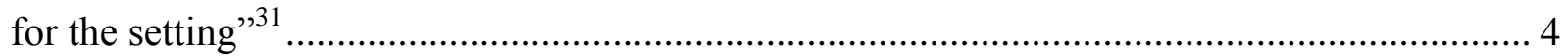

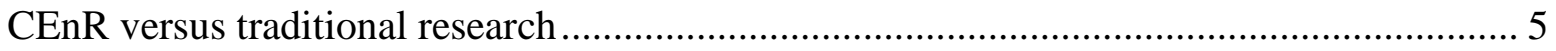

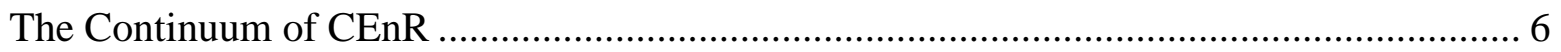

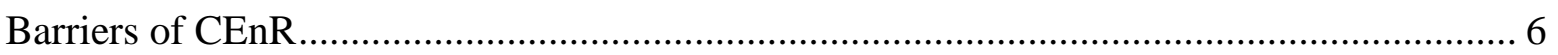

Coalitions: The Pathway to Community Capacity …....................................................... 7

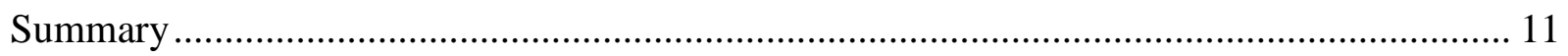

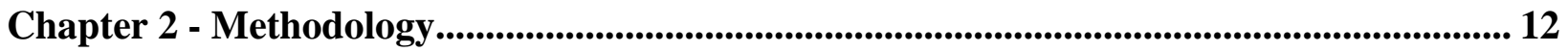

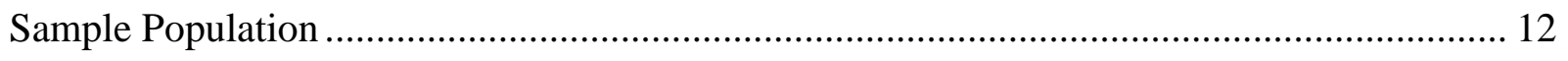

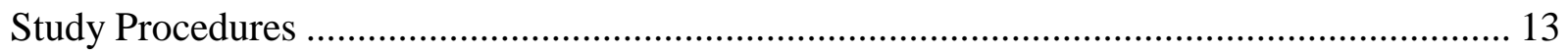

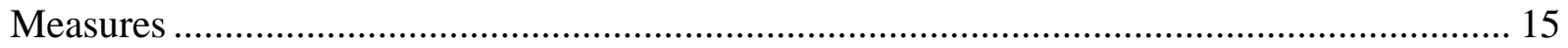

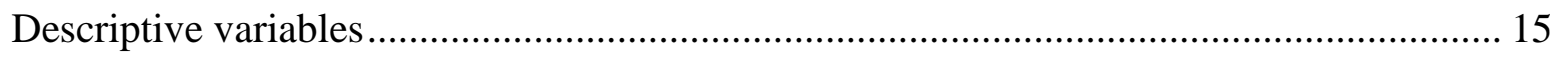

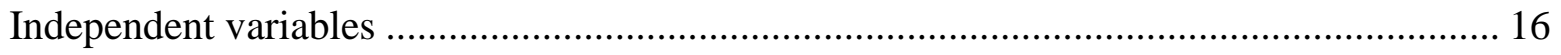

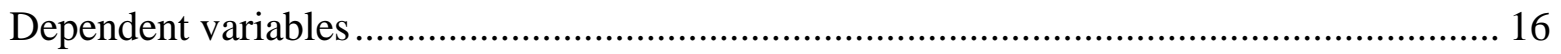

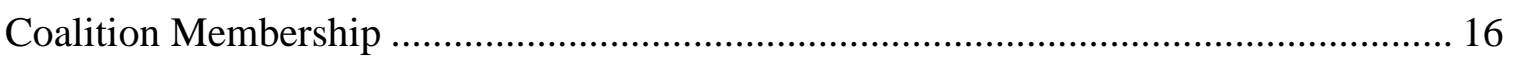

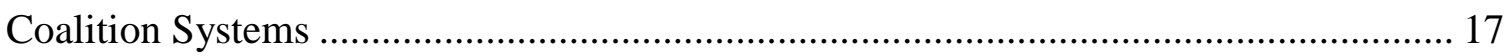

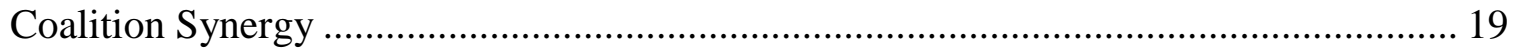

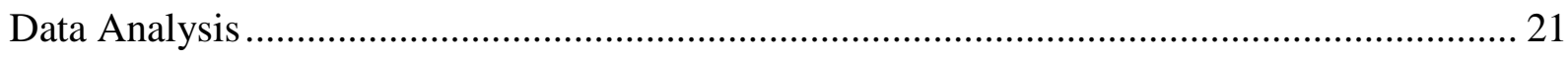

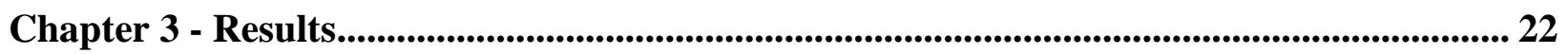

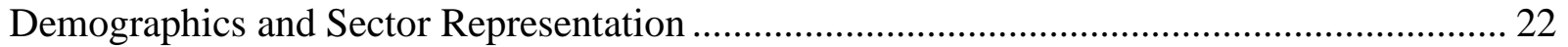

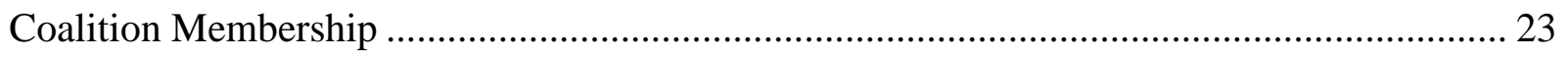

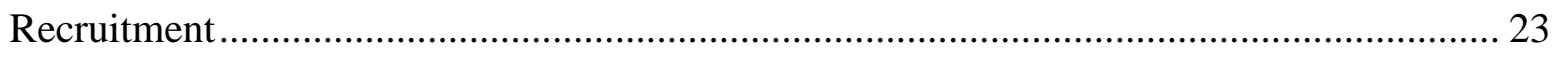

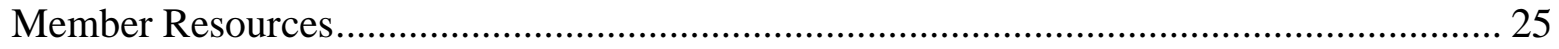




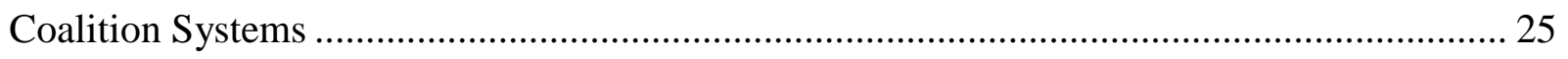

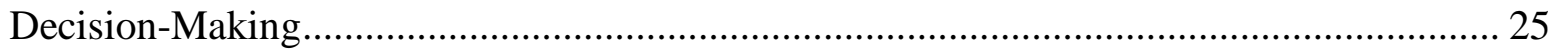

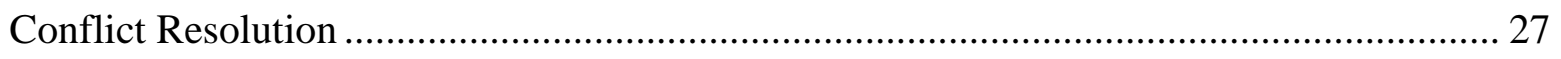

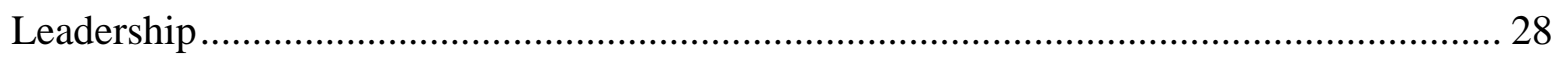

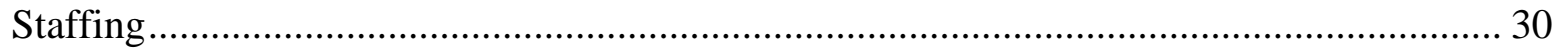

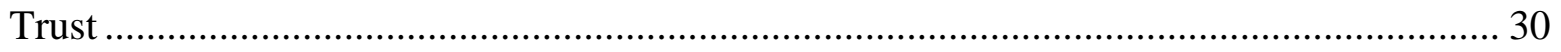

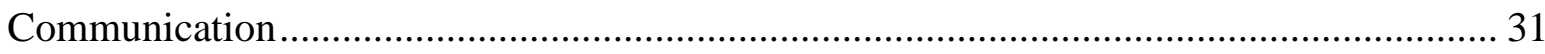

Coalition Capacity ................................................................................................ 32

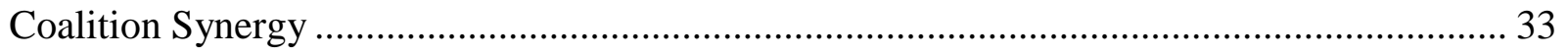

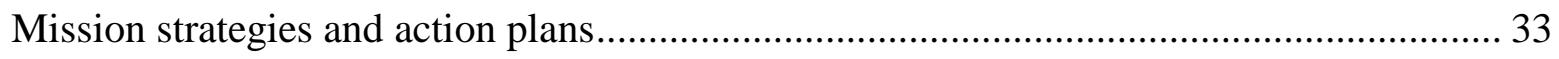

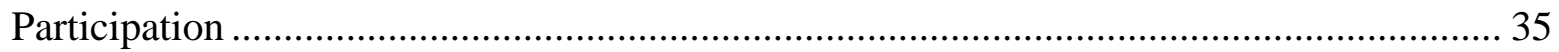

Chapter 4 - Discussion ....................................................................................................................... 39

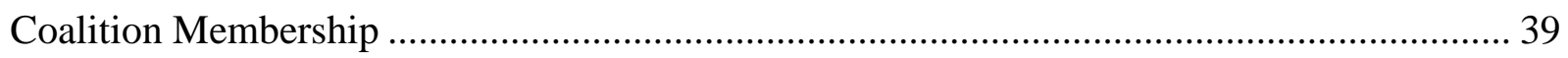

Coalition Systems: Structures, Operation and Processes, Leadership and Staffing ................. 40

Synergy: Member Engagement, Assessment and Planning...................................................... 41

Experimental Considerations ............................................................................................ 41

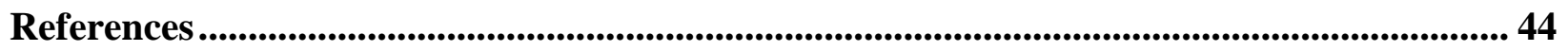

Chapter 5 - Field Experience ................................................................................................................... 51

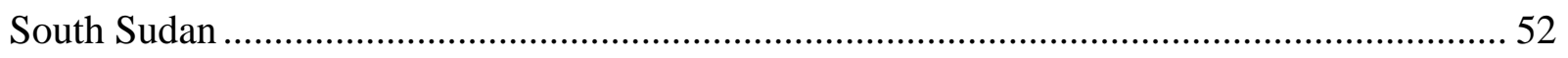

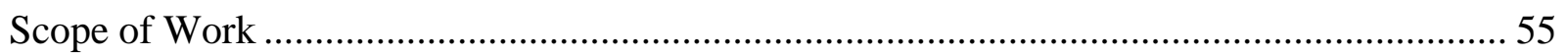

Learning Objectives ……………………………………............................................. 57

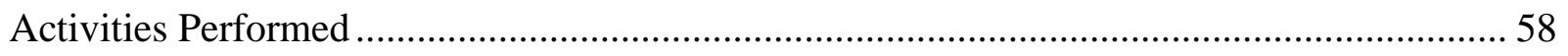

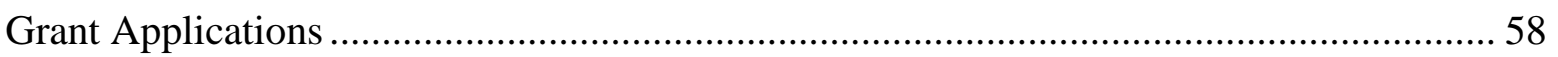

Annual Fundraising Dinner and Silent Auction................................................................. 60

Community Engagement ………………………………………………………… 61

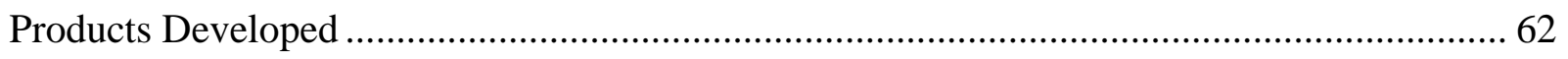

Alignment with Public Health Core Competencies ................................................................ 63

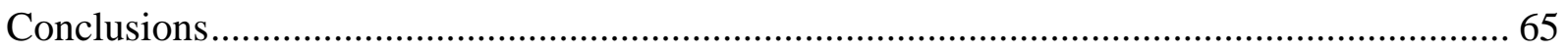

References...................................................................................................................................................... 66

Appendix A - Community Application ................................................................................................. 68

Appendix B - Coalition Self-Assessment Survey ................................................................................ 71 
Appendix C - Self-Assessment Template for Coalition Feedback................................................. 86

\section{List of Figures}

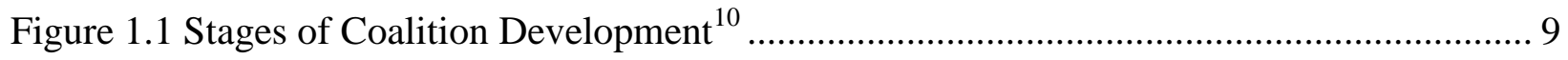

Figure 1.2 Community Coalition Action Theory ${ }^{80}$............................................................... 10

Figure 3.1 Group differences between coalition member opinion of organizational capabilities 24

Figure 3.2 Group differences between coalition member opinion of coalition impact ............... 32

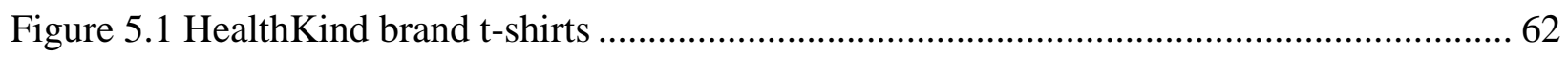

Figure 5.2 Poster for the first Peace for South Sudan dinner................................................ 62

Figure 5.3 Ecological Model of Childhood Overweight ..................................................... 65 


\section{List of Tables}

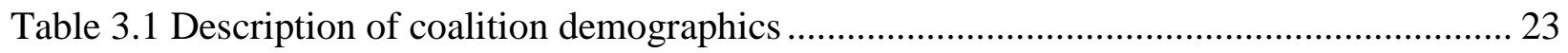

Table 3.2 Chi-square analysis of recruitment variables ....................................................... 24

Table 3.3 Mann-Whitney $U$ tests for membership variables ............................................. 25

Table 3.4 Chi-square analysis of decision-making variables.............................................. 26

Table 3.5 Mann-Whitney rank tests for decision-making variables ...................................... 26

Table 3.6 Chi-square analysis of coalition conflict ....................................................... 28

Table 3.7 Mann-Whitney rank tests of conflict variables....................................................... 28

Table 3.8 Mann-Whitney rank tests of leadership variables................................................ 29

Table 3.9 Chi-square analysis of coalition staffing variables ........................................... 30

Table 3.10 Mann-Whitney rank tests for coalition trust variables........................................ 31

Table 3.11 Mann-Whitney $U$ tests for measures of coalition communication .......................... 31

Table 3.12 Chi-square analysis of variables that gauge coalition capacity ............................. 33

Table 3.13 Mann-Whitney U rank tests for coalition capacity measures ................................. 33

Table 3.14 Mann-Whitney $U$ rank tests for mission strategy and action plan variables ............. 34

Table 3.15 Mann-Whitney $U$ rank tests for mission strategy and action plan variables ............. 35

Table 3.16 Mann-Whitney U rank tests for tests of coalition participation benefits .................. 36

Table 3.17 Mann-Whitney $U$ rank of variables testing coalition member perception of barriers to

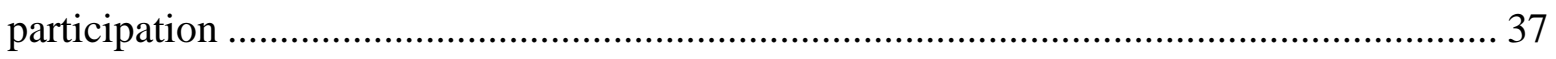

Table 3.18 Mann-Whitney $U$ rank of variables testing the costs and benefits of member

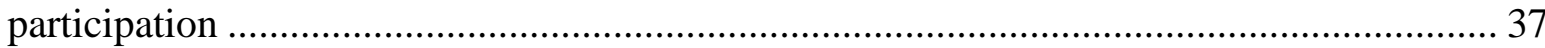

Table 3.19 Mann-Whitney U rank tests of participation variables ........................................ 38 


\section{Acknowledgements}

I would like to express my gratitude to the faculty and staff of Kansas State University for their support and guidance during my graduate studies. To Dr. Sandy Procter: you have been more than a major professor to me, you have been my friend, sounding board, travel buddy, master editor, but most of all you have been an amazing mentor. Thank you for taking me under your wing, supporting my need to get involved with every new project and truly allowing me practice public health firsthand. I also wish to thank my committee, Dr. Paula Peters and Dr. Michael Cates, for their steady support and advocacy. Dr. Carol Holcomb, thank you for your direction and advice regarding my data. Dr. Cates and Barta Stevenson, thank you for bringing me to Kansas State, guiding me through the MPH program and most of all for the endless hours of hard work getting our program accredited.

I am thankful to Kansas State University, the College of Human Ecology, Dr. Mark Haub and the Department of Human Nutrition for financially supporting my research. I am grateful to Dr. Paula Peters and Dr. Tina Remig for their direction and solidarity on CPCO. To Dr. Sajid Alavi, I am thankful for your leadership and encouragement throughout our MFFAPP project.

I must express my deep appreciation to Rhonda Parmley at HealthKind. Thank you for showing me how much hard work, dedication and heart goes into running a global nonprofit. Your kindness, selflessness and positivity radiate through the core of HealthKind, and I am lucky

to have had the chance to work with you. Kuier Atem, thank you for trusting me and teaching me about South Sudan and what it is like to be a Dinka woman.

To my friends and family, I am grateful for your love and encouragement. Scarlett and Bessie, thank you for your patience, I know it was "ruff". To my partner and walking thesaurus, Michael, I don't know what I would do without you, thank you for having my back. 


\section{Dedication}

For the communities, near and far, affected by lack of access. 


\section{Chapter 1 - Review of the Literature}

According to the CDC, health disparities are "a type of difference in health closely linked with social or economic disadvantage." ${ }^{\prime 1}$ This term often invokes images of stark contrasts in health status among geographic locations, particularly between developed and underdeveloped countries. However, these disparities are not always so evident. Rural Americans have disproportionately higher rates of preventable diseases (including obesity, diabetes and cancer) ${ }^{2,3,4}$ and health-risk behaviors (such as smoking, physical activity, and poor diet), ${ }^{2-5}$ While there is a growing focus on eliminating health disparities in rural environments, much of the emphasis has been placed on increasing individual access to care ${ }^{4}$ rather than on encouraging collaboration between sectors and communities with specifically defined objectives. ${ }^{6}$

Community-based approaches to public health have been utilized in both developed and developing communities to address health disparities. ${ }^{7-9}$ Coalitions, community partnerships, and related approaches have been identified as promising strategies to engage local stakeholders. ${ }^{10-13}$ Although community-engaged research (CEnR) has been employed within public health initiatives over the past decade, ${ }^{8}$ there is limited published literature that evaluates how CEnR processes transpire. ${ }^{7,8,11,14}$ Thus, it is meaningful to identify the characteristics and capacities of partners involved in CEnR projects. ${ }^{10,15}$

The purpose of this review is to examine the relevant literature regarding partnerships between the community and researchers in public health. The review provides a broad overview of rural health, community-based approaches to health interventions, and the role of community coalitions in public health research. 


\section{Rural Health in the United States}

A mere 15 percent of the United States population lives in rural areas that constitute 72 percent of the nation's land mass. ${ }^{16}$ Rural populations are burdened by the same barriers to health that affect other communities nationally, ${ }^{17}$ including lack of availability, high costs, lack of insurance coverage, ${ }^{18}$ and language. ${ }^{19}$ While these hurdles are universal, the geographic isolation of rural populations, in particular, exacerbates their impact. When compared with urban areas, rural communities are often less educated, possess a lower socioeconomic status, have a greater proportion of elderly residents, and demonstrate a higher occurrence of chronic medical conditions. ${ }^{16-18,20}$ Rural communities are also disproportionately affected by a lack of healthful food options ${ }^{21}$ and limited access to recreational facilities and activities. ${ }^{22}$ Further perpetuating this problem is a lack of state and national health policies and programs in these regions due to a lack of locally available data. ${ }^{23}$ The absence of such programs further exacerbates the obstacles already faced by these populations. Access to healthcare is a significant contributor to the health disparities plaguing rural Americans, and much of the current literature focuses solely on this barrier. ${ }^{18,23,24}$ Unfortunately, means of improving accessibility tend to concentrate on building the rural healthcare workforce, ${ }^{24,25}$ yet there is little evidence that such strategies appreciably enhance preventive services and resources. ${ }^{23}$

Rural populations have higher rates of tobacco use, lower rates of physical activity, and demonstrate lower consumption of fruits and vegetables. ${ }^{2-5,21}$ These behavioral risk factors are associated with lower incomes and education levels ${ }^{17,23}$ that are characteristic of rural regions. Mortality and morbidity rates due to chronic disease in rural communities are also higher, ${ }^{17,20}$ which is likely related to these behavioral risk factors. Even residents' perception of their health 
is lower, as denizens of rural areas were more likely than their metropolitan counterparts to respond that they were in fair or poor health. ${ }^{17}$

Children living in rural communities may be 25 percent more likely to be overweight or obese. $^{21,27}$ One study estimated that when controlling for race, income, and parental education, this figure increases to 54.7 percent risk. ${ }^{28}$ Evidence suggests that environmental effects in rural communities are primarily to blame for these rates of overweight and obese, ${ }^{29}$ which may be due in part to small population sizes with low tax bases. ${ }^{30}$ Effects of limited local governments and sparsely populated communities that may impact childhood weight status include: few available open public spaces nearby, neglect of spaces that are public, dangerous roadways with few marked pedestrian crossings, and lack of access to fresh fruits and vegetables. ${ }^{30}$

From a perspective of the social ecological theory, the health inequities of rural populations are socially and culturally constructed, determined, and interrelated. ${ }^{31}$ The increased burden of disease in rural populations is the combined result of individual, relationship, community, and societal factors. ${ }^{31,32}$ Over the past 15 years, an ecological approach to public health has garnered greater attention. ${ }^{33-36}$ By examining and better understanding the interplay of external and internal factors along the social ecology continuum, interventions that address health disparities in rural communities are more likely to succeed and persist. ${ }^{31,35,37}$ For individual behavioral change to be sustained, it must be supported by an environment that encourages progress. To this end, engaging local stakeholders has been identified as a critical step for targeting groups in the U.S. that at one time were considered inaccessible. ${ }^{24,25,32,38}$

In developing countries, it is widely accepted that whole community participation and the engagement of specific partners is essential to the success of health intervention programs. ${ }^{32,38-40}$ Rural communities in the U.S. may benefit from the same attention by tailoring user-specific 
programs. While such communities may share some common attributes, the "one-size-fits-all" approach to addressing health inequities is ineffective since it fails to meet population-specific needs. ${ }^{24,38}$ Even though uniformly implemented policies may appear translatable, recent experience argues otherwise. Researchers have noted that public health in rural America more commonly manifests as an "informal collaboration of non-public health partners and volunteers" rather than as a formal agency. ${ }^{23}$ Engaging communities in a partnership approach has been identified as a promising strategy to align local practices with evidence-based health interventions, thereby ensuring the successful uptake of these programs. ${ }^{20,23,24,37,38,41}$

\section{Community Engagement and Public Health: "Applying what works, and doing what is right for the setting,"31}

Traditionally, research was conducted with a top-down approach: labs and clinical/academic institutions had little involvement with the intended beneficiaries. ${ }^{42}$ However, these methods fail to address complex problems unique to distinct communities. ${ }^{20,23,24,43-45}$ Alternatively, CEnR is viewed as "the keystone to translational medicine and improving the health of the nation." 14 Defined as a "continuum of possibilities for research conducted with community partner participation, ${ }^{46,} \mathrm{CEnR}$ is not a research method, ${ }^{37,47}$ but rather an approach to research. It functions as a framework for conducting research with an ecological approach, ${ }^{9}$ in which methods of evidence-based research are employed with a community focus. ${ }^{8,48}$ These approaches may be used with either qualitative or quantitative research. ${ }^{49}$ It is important to note that the term "community" is commonly used to refer to a cluster of individuals in a defined geographic area. In the context of CEnR, however, "community" may be used to focus on a local shared identity or relation. ${ }^{42,48}$ 


\section{CEnR versus traditional research}

The majority of published literature on CEnR focuses on the structure of partnerships or capacity change in a given community. ${ }^{11,12,14,24,37-40,50-62}$ In comparison to traditional research approaches, involvement of the community has been found to enhance project quality, likely due to the unique perspectives offered by engaged partners. ${ }^{48,63}$ Research demonstrates that employing CEnR may strengthen the quality of findings, ${ }^{63,64}$ improve health outcomes, ${ }^{14,63,65-71}$ and reduce health inequity. ${ }^{14}$ Incorporation of community stakeholders in all steps of the research process is tantamount to CEnR's demonstrated success. These steps include:

- Development of research questions (Language $)^{72}$

- Subject recruitment

- Identification of subject risk

- Improved outcome measurement tools

- Data analysis and interpretation

An added benefit of CEnR is that research findings are more translatable to practice due to unified recommendations to inform and influence policy. ${ }^{47}$ As such, the sustainability of programs and resources is also enhanced. ${ }^{63,73}$ While building community capacity is rarely acknowledged as an outcome of community-based research, it is often a key element in the process. ${ }^{63}$ Several studies have demonstrated enhanced capacity through additional grant funding, job creation, skill building, coalition empowerment and the success of effective programs. ${ }^{63,73}$ The ability to conduct research was frequently reported as evidence of strengthened capacity. ${ }^{63}$

Unlike traditional research, the manner in which CEnR contributes to intermediate- and longterm outcomes may not be clear. ${ }^{57}$ Also, due to the nature of CEnR, randomized controlled trials 
may not be practical or ethical (e.g. in cases where one group is offered treatment, and the other is not). ${ }^{63}$ Most notably, change may not be evident as quantifiable progress toward long-term health outcomes because these indicators (morbidity and mortality) can require a decade or longer to manifest. ${ }^{57}$ Moreover, much of the published literature regarding health outcomes describes highly varied treatment approaches, so studies are difficult to compare. Of studies that reported a positive impact on health outcomes, it was not determined that those impacts were attributable to CEnR. ${ }^{63}$ Yet data from CEnR case studies that examine behavioral risk factors (e.g. teen sexual risk reduction and pregnancy, lead poisoning, and alcohol-related motor vehicle accidents) suggest that CEnR may enhance the uptake of long-term outcomes. ${ }^{9}$

\section{The Continuum of CEnR}

In research, community engagement occurs on a continuum, ${ }^{9,48,49}$ ranging from low to high levels of collaboration. Variations in the partnership approach include strength of engagement, research objectives, scale of target, length of study, community history, and politics. These variants result in an array of collaboration levels. ${ }^{48}$ Community-based participatory research (CBPR) is a form of CEnR that represents the apex of a community partnership approach. ${ }^{47} \mathrm{CBPR}$ is an enhanced form of CEnR characterized by involvement of the community in every aspect of a research project: from identifying the objective, to study design and data collection, to analysis and dissemination. ${ }^{47-49}$ While the term CBPR is often misused in labeling research that involves any degree of community engagement, many of these projects do not meet the precise definition of CBPR in its entirety. ${ }^{42}$

\section{Barriers of CEnR}

Working with community partners brings unique challenges. First, a long history of research abuse leaves community partners weary of involvement in academic research, ${ }^{14}$ as 
previous public health studies were conducted "on," rather than alongside, communities. ${ }^{48,74}$ Additionally, sociocultural differences between academic and community partners may be a barrier to establishing a strong working relationship. ${ }^{63}$

Another barrier to CEnR is the issue of time. Community partners cite competing priorities as they assume research as an added responsibility outside of (or in addition to) their standing role in the community. ${ }^{47,48}$ One article reported that the loss of staff availability due to involvement in CEnR reduced community exposure; the same article reported that community partners may have introduced recruitment bias into the research process. ${ }^{63}$

Unrealistic expectations of community members was also reported as a barrier in some studies. ${ }^{48,65,69}$ Community members may expect results shortly after a project concludes, so the time that it takes to analyze and publish data could be alienating. ${ }^{48}$

Barriers to research do not exist solely at the community level, as academic partners also encounter challenges. A major consideration for researchers is time; planning research studies, building relationships, and communicating with stakeholders requires a considerable investment. ${ }^{48}$ And as noted above, the time it takes to achieve an appreciable population change can also be limiting. ${ }^{57}$ In relation to the unrealistic expectations discussed, the dissemination of findings can also be challenging: many academic journals do not publish articles whose findings have been reported previously, thereby restricting the authors from releasing outcomes to the community. ${ }^{48}$ While CEnR approaches have become more mainstream, securing funding for non-conventional research projects may be difficult. ${ }^{48,75,76}$

\section{Coalitions: The Pathway to Community Capacity}

Community coalitions are comprised of community activists that mobilize locally to promote improved conditions for their community. ${ }^{77}$ Coalitions may include parents, teachers, 
government officials, law enforcement officers, business owners, non-profit groups, religious leaders, health providers, or simply concerned citizens. ${ }^{52}$ In the United States, there are thousands of community coalitions focused on improving health issues. ${ }^{52}$ These groups represent a rich resource of abilities and expertise and are a logical partner in the employment of CEnR. ${ }^{60}$

A key benefit to engaging community coalitions is that they can reduce the burden of time and increase manpower. Coalitions obviate the arduous process of identifying key stakeholders in the community, establishing connections and pooling local expertise and resources. ${ }^{38}$ Also, health-focused coalitions usually have a predetermined agenda for solving complex health problems affecting their community, ${ }^{7,38,59}$ such coalitions have pre-established roles in local community health outreach, media campaigns, health screenings, classes, and support groups. ${ }^{59}$

The principal challenge of partnering with community groups is that not all coalitions are created equal. Coalitions do not report to a governing body, ${ }^{59}$ tend to be volunteer-based, ${ }^{15}$ and vary in the quality of infrastructure. ${ }^{10,60}$ Numerous frameworks exist that attempt to determine the processes and characteristics that lead to a given coalition's success ${ }^{60}$ Florin et al. proposed that community coalitions move through stages of development that eventually lead to community action. The stages described in the study include initial mobilization, establishing an organizational structure, building capacity for action, planning for action, implementation, refinement, and institutionalization. ${ }^{10}$ 


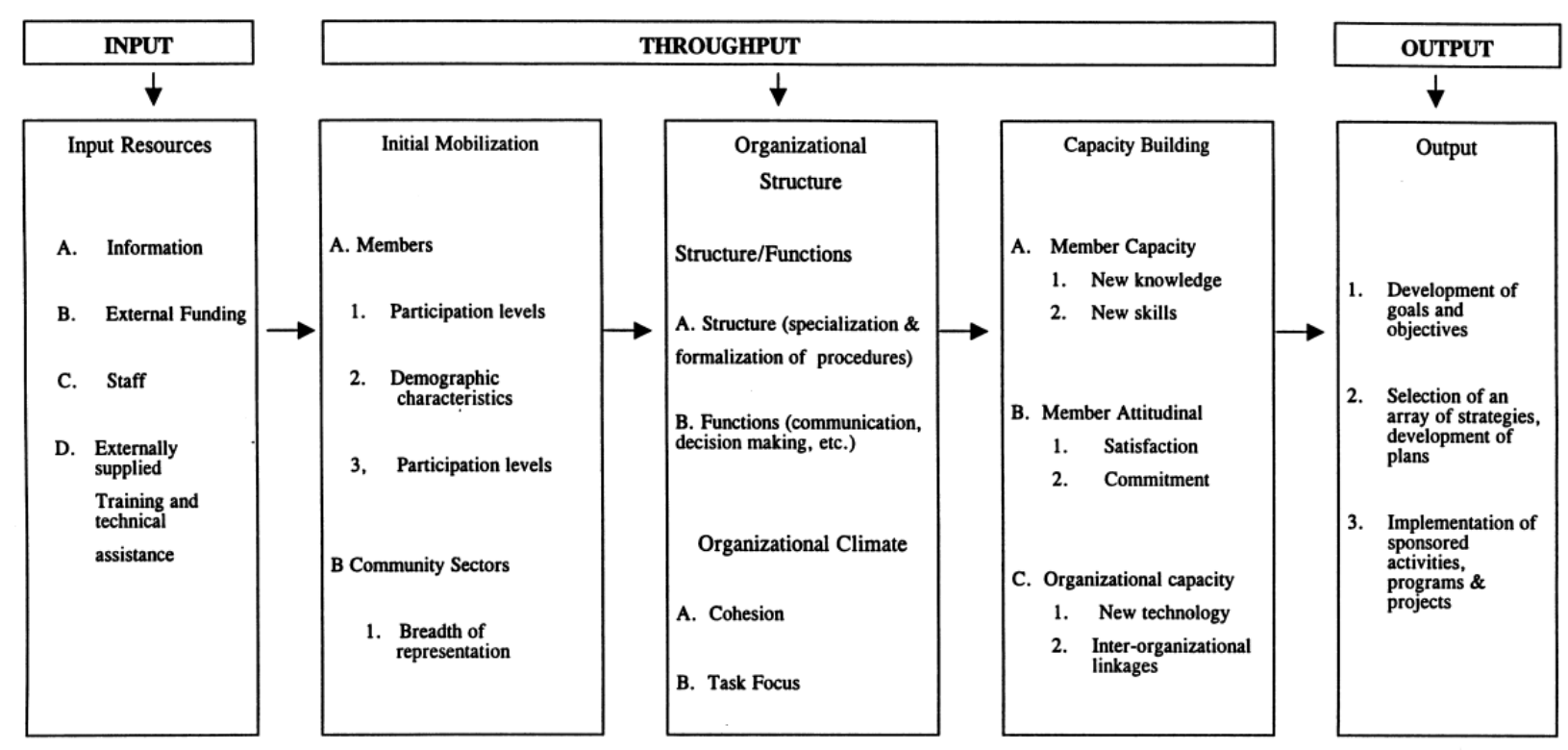

Figure 1.1 Stages of Coalition Development ${ }^{10}$

Later, Butterfoss and Kegler advanced these principles with their Community Coalition Action Theory (CCAT). The researchers theorized that coalitions are iterative and evolve through the previously proposed stages of development as they form, maintain, and address new issues. The CCAT incorporates key concepts, external factors and internal processes along the stages of coalition development, designating fourteen constructs that provide a framework for understanding the characteristics that facilitate coalition success. ${ }^{62}$ More recently, Kegler and Swan posited that the CCAT should be altered to include a direct path between coalition processes, leadership, and staffing to community capacity, since coalition member engagement (defined as participation and satisfaction) is not necessarily the key mediating variable. ${ }^{78}$ Ongoing evaluation and continuous feedback, ${ }^{79}$ through external or internal evaluation, are necessary to continually refine and modify plans and strategies and/or put new ones in place, ${ }^{52}$ 

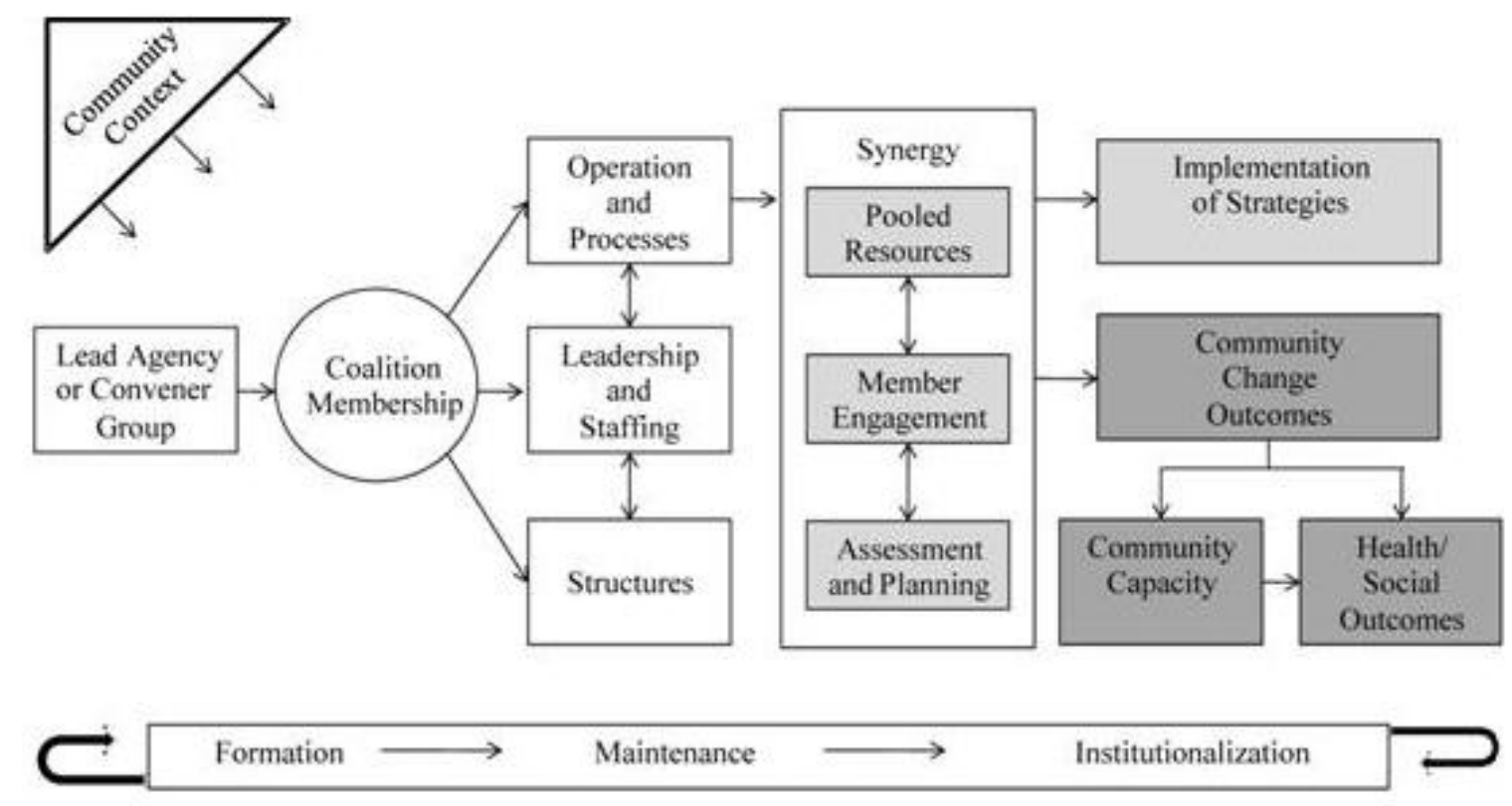

Figure 1.2 Community Coalition Action Theory ${ }^{80}$

While the Stages of Coalition Development and the CCAT constructed a road map to coalition development, these methodologies cannot measure the association between coalition characteristics and a community's capacity to respond to public health problems. ${ }^{51,59,78}$ Although several studies have reinforced the logic behind the CCAT (linking coalition constructs to shortand intermediate-term indicators of coalition efficacy, ${ }^{4,7,13,78,81-84}$ long-term measures are lacking. ${ }^{51}$ These findings echo the challenges of CEnR already discussed: that measuring longterm health outcomes may require a decade or longer to appreciate a change in health status. ${ }^{57}$ Unfortunately, these timelines are not practical for three-to-five year projects. ${ }^{52}$ Similarly, few studies have documented a change in health systems relative to coalition action. ${ }^{85}$

Although community coalitions are frequently utilized as partners for CEnR projects, there is a gap in the literature that addresses how these partnerships affect established community groups. It is suggested that future research on community coalitions should be based in coalition theory or assess theoretical constructs. ${ }^{78,85}$ 


\section{Summary}

While public health efforts rooted in local communities (often via CEnR approaches) have been successful in addressing complex health problems and reducing health disparities, ${ }^{4,32,38-40,81}$ there is limited information that addresses the evolutionary process of researcher/community partnership..$^{14,57,75,85}$ Historically, researchers have focused on health outcomes, but those measurements are not always practical for the duration of a project ${ }^{57,59}$ and may not address how those outcomes manifested. ${ }^{63}$

No studies were identified that evaluated changes in coalition characteristics after the pilot year of a CEnR partnership. Furthermore, no studies compared the level of researcher involvement (hands-off versus intensive) on the success of community coalitions in a doseresponse type study. According to the CCAT, coalition function influences community health outcomes indirectly through the iterative process of coalition evolution. ${ }^{62}$ When a coalition partners with researchers, it can be inferred that the constructs determining coalition progress have been altered, therefore impacting the community's capacity to address public health issues. This study seeks to evaluate the effects of CEnR partnership on existing rural community health coalitions involved in the pilot year of a project named Mobilizing Rural Low-income Communities to Assess and Improve the Ecological Environment to Prevent Childhood Obesity. 


\section{Chapter 2 - Methodology}

This study is a component of Mobilizing Rural Low-income Communities to Assess and Improve the Ecological Environment to Prevent Childhood Obesity, a collaborative, multi-state, multi-disciplinary research project to address childhood obesity in low-income, rural communities. The purpose of this overarching study was to examine the extent to which an Extension intervention, focused on building community capacity using a community-coaching model in rural community coalitions, contributes to the communities' increased ability to prevent childhood obesity. At the time of conception, this was the first research study to bring academic researchers from multiple states together in a community development approach to address health disparities in rural communities.

Procedures were reviewed by the Institutional Review Boards of Kansas State University and academic institutions in partner states to ensure that participants would be fully informed and that consent was obtained in all instances.

This project was supported by the Agriculture and Food Research Initiative, Grant Number: \#2011-68001-30100, from the USDA National Institute of Food and Agriculture, Childhood Obesity Prevention: Integrated Research, Education and Extension to Prevent Childhood Obesity, Program Code A2101.

\section{Sample Population}

The study population consisted of fourteen pre-existing community health coalitions located in rural low-income communities in seven states. Two coalitions from each of the following seven states were identified to partner with academic researchers over four years: Indiana, Kansas, Michigan, North Dakota, Ohio, South Dakota, and Wisconsin. South Dakota, 
with two initial coalitions, had one coalition compromised during year one and was excluded from analysis.

All community coalitions selected met the following inclusion criteria:

- Coalition must already exist and display interest in preventing childhood obesity

- Strong Extension Family and Consumer Sciences Educator presence

- Classified as "Rural" by the USDA (population less than 49,999 people)

- Poverty rate greater than $14.3 \%$ (national average)

- High participation of children in preschool programs

- Able to commit to a four year project (2012 - 2016)

- Within states, communities must be comparable in size and demographics

Additionally, coalitions completed a rigorous application process to demonstrate ability to address childhood obesity in their community (Appendix A).

\section{Study Procedures}

Utilizing a quasi-experimental design, two community coalitions from each of seven states were selected to partner with academic researchers. State-specific research teams were responsible for selecting the two community coalitions that best aligned with project inclusion criteria. The two coalitions were then randomized to an intervention or control protocol.

- Both groups were provided $\$ 5,000$ annually to support the implementation of evidencebased interventions targeted at building healthful environments for four-year-old children.

- Coalitions assigned to the intervention group were provided resources to hire a half-time, trained, community coach who led community capacity building activities. Coaches led the intervention coalitions in identifying appropriate project activities that met local 
needs, determining activities that could have the most impact on the prevention of childhood obesity, and developing a plan to implement those activities. Coalitions in this group were also provided a menu of evidence-based and evidence-informed interventions and strategies to assist the intervention coalitions in implementing strategies to improve the environments of 4-year-old children.

- Coalitions assigned to the control group received no community coach or project team involvement beyond providing a menu of evidence-based and evidence-informed interventions and strategies to assist coalitions in implementing strategies to improve the environments of 4-year-old children. This was the same menu made available to the intervention group.

Coalitions were overseen by academic partners consisting of a project director (PD) and state-specific co-PDs. Project coordinators were hired to manage the project in each of the seven states.

At baseline (fall of 2012), all members of the fourteen coalitions were asked to complete the Coalition Self-Assessment Survey (CSAS), ${ }^{83}$ regardless of the length of their personal coalition involvement. Surveys were distributed by mail or at coalition meetings ${ }^{*}$ and returned directly to the project coordinator and/or PD at the same coalition meeting or by mail. ${ }^{\dagger}$ The survey took approximately 30 minutes to complete. Responses were confidential and were only coded according to state and treatment group. Methods for completing the survey varied by state.

During the pilot year of the project, coalitions were charged with identifying and implementing intervention(s) to address childhood obesity locally. Each coalition was provided

\footnotetext{
* Coalition members were notified that academic partners would be attending the monthly coalition meeting prior to the meeting time.

${ }^{\dagger}$ When coalition members were asked to submit the completed survey by mail, return postage was provided to them.
} 
$\$ 5,000$ to support project implementation. Community coaches became actively involved with treatment coalitions.

One year post (fall of 2013), all current members of the fourteen coalitions were asked to complete the CSAS, regardless of if they had completed it at baseline. Methods for completing the survey varied by state and did not necessarily correspond to the method of collection utilized in that state at baseline. All surveys remain anonymous.

\section{Measures}

The CSAS tool was used to capture quantitative data regarding coalition structure, functioning, leadership and effectiveness of effort (Appendix B). The CSAS was developed in 2000 by the Robert Wood Johnson Foundation as a tool for coalitions to gain feedback regarding how coalition members perceive coalition functioning. ${ }^{83}$ The CSAS consists of 41 key questions and is available in English and Spanish. The CSAS has previously been identified as a promising instrument for measuring components of the CEnR approach based on the high face validity ${ }^{12}$

and in-depth use of the tool within the respective setting. ${ }^{86}$ Coalition-specific results were analyzed according to a generic template (Appendix C) and reported back to individual coalitions for self-evaluation.

\section{Descriptive variables}

Demographics. Gender, race/ethnicity, age, and education level were variables included in the survey.

Sector representation. Those who reported representing groups or organizations were asked to indicate type from a list of 30 options including other. 


\section{Independent variables}

Engagement of coalition in a research partnership. At baseline, measures of coalition structure and function were representative of active rural community health coalitions not involved in a CEnR partnership. The same measures were repeated at one-year follow-up after partnering with academic researchers in the CEnR-based project. Variables are defined as baseline and follow-up.

"Dose" of coalition engagement. Although all coalitions are partnered in CEnR, coalitions in the intervention group have a stronger degree of exposure to academic partners (dose) with the insertion of a trained community coach. Variables are defined as control or intervention group.

\section{Dependent variables}

\section{Coalition Membership}

Recruitment. Community sector (defined as community groups, organizations and/or schools) involvement was evaluated by asking members three "yes or no" questions regarding group representation, active recruitment, and member orientation in the coalition. Respondents were also asked to select appropriate reasons for a lack of representation, if indicated, given a list of 8 possible answers including: the coalition never tried to involve them, the coalition invited them but they chose not to participate, they used to participate but dropped out, the coalition cannot get access to representatives of this group, the coalition as a whole is not sure that this group should be asked to join, resources are lacking to recruit new members, some coalition members do not want to share power with this group and don't know. 
Member Resources. Member resources and skills were assessed with one question asking respondents to indicate the approximate percentage of members who have enough authority to support the coalition. The responses consisted of a 4-point Likert-type scale with $1=$ less than one-quarter of the members to $4=$ nearly all of the members.

\section{Coalition Systems}

Decision-Making. Member influence in various types of decisions was assessed by asking respondents to rank the level of influence of the coalition chair, officers or committee chairs, lead staff, coalition members and self on a 3-point Likert-type scale ranging from $1=$ no influence to $3=$ a lot of influence. Member comfort with the decision-making process was assessed similarly with a 3 -point Likert-type scale ranging from $1=$ not at all comfortable to $3=$ very comfortable. Method of decision-making was evaluated by respondent selection of one of 6 possible answers including coalition members vote with majority rule, coalition members discuss the issue and come to consensus, the coalition chair makes final decisions, the coalition executive or steering committee makes final decisions, the lead agency for the project makes the decisions and don't know. Lastly, respondents were asked to indicate level of agreement with statements regarding the clarity, procedures, fairness, timeliness, and satisfaction with the coalition decision-making process. Response options ranged from $1=$ strongly disagree to $4=$ strongly agree.

Conflict Resolution. Amount of conflict was gauged based on respondent indication of their expectations when asked to choose between the following: more conflict than I expected, less conflicted than I expected, or about as much as I expected. Tension in the coalition was evaluated by asking respondents to rank how much conflict within the coalition was caused by 10 different factors. Examples include differences in opinion, personality clashes, procedures, 
and dominant members. Response options ranked from $1=$ none to $3=$ a lot on a 3 -point Likerttype scale. Strategy to address conflict in the coalitions was evaluated by respondent selection given 6 possible answers including open debate about opposing viewpoints, postponing or avoiding discussions of controversial issues, having a third party mediate between those with opposing viewpoints, having the opposing parties negotiate directly with each other, one party to the conflict gives in, or don't know.

Leadership. Skills in guiding the coalition toward accomplishment were measured by asking respondents how much they agree or disagree with 14 items regarding the leadership of the coalition. Examples include respect, productivity, collaboration, focus, and ethics. Response options ranks from $1=$ strongly disagree to $4=$ strongly agree on a 4-point Likert-type scale.

Staffing. Guidance and support for coalition responsibilities was assessed by asking respondents to indicate who set the agenda for meetings given the following choices: coalition chair, coalition officers or committee chairs, lead staff, coalition members, and don't know. Staff skill and member responsibility were assessed through 4 items on a 4-point Likert-type scale with 1 = strongly disagree to 4 = strongly agree.

Trust. Asking respondents how much they agree or disagree with 7 items related to trust assessed member comfort with coalition relationships. Examples include relationships with other members that go beyond the coalition, the ability to have open conversations, expressing personal opinions, and respect. Response options ranked from $1=$ strongly disagree to $4=$ strongly agree on a 4-point Likert-type scale.

Communication. Productivity of contact between members was assessed by asking respondents how much they agree or disagree with 5 items regarding coalition communication 
efficacy assessed. Examples include method, action, and efficiency. Response options rank from $1=$ strongly disagree to $4=$ strongly agree on a 4-point Likert-type scale.

Coalition Capacity. Health outcome-related knowledge was assessed with two questions. The first asked respondents if they feel they have adequate knowledge about childhood obesity to function effectively in the coalition. The second question asked if the coalition advanced member knowledge of childhood obesity. Response type was a categorical yes or no. Perceived coalition success was a measured with two questions that asked if the coalition was responsible for activities or programs that otherwise would not have occurred, and if the coalition brought benefit to the community. Response type was a categorical yes or no. Respondents were also asked to rank their level of agreement regarding coalition progress in implementing targeted activities and improving health outcomes for at-risk populations. Response options ranked from $1=$ strongly disagree to $4=$ strongly agree on a 4-point Likert-type scale. Asking respondents how much they agree or disagree on 6 items related to future plans, establishing resources, and coalition value assessed coalition readiness and sustainability. Response options ranked from $1=$ strongly disagree to 4 = strongly agree on a 4-point Likert-type scale.

\section{Coalition Synergy}

Mission strategies and action plans. Coalition function was evaluated by asking respondents to rank 10 distinct coalition action items including: networking with other professionals, networking with concerned citizens, conducting strategic planning, making decisions about priority needs and problems, recommending or making decisions to allocate resources, operating particular programs or activities, advocating for local public policy objectives, advocating for state public policy objectives, providing funding for current programs, and raising funds to sustain long-term coalition activities. Response options ranked from $1=$ not 
a function to 3 = a major function on a 3-point Likert-type scale. Coalition action plan clarity, strategy to achieve the mission of coalitions, and organization was assessed by level of agreement on 8 items. Responses ranged from $1=$ strongly disagree to $4=$ strongly agree on a 4 point Likert-type scale.

Participation. Respondents self-reported their level of participation from $1=$ not at all to $4=$ very involved on a 4-point Likert-type scale. Individual member participation in key coalition activities was assessed by member indication of frequency on 5 items. Response options ranked from 1 = never to 4 = often on a 4-point Likert-type scale. Organizational participation was assessed by respondent agreement on 5 items related to organization-based support and commitment. Response options ranked from $1=$ strongly disagree to $4=$ strongly agree on a 4-point Likert-type scale. Member satisfaction, as indicated by level of activity and time committed, was measured by asking respondents how much they agree or disagree with 4 items. Response options ranked from 1 = strongly disagree to $4=$ strongly agree on a 4 -point Likert-type scale. Benefits of organization-based participation were measured by respondent rank of 11 items. Examples include developing collaborative relationships with other agencies, getting client referrals from others, staying well informed in a rapidly changing environment and getting access to key policy makers. Response options ranked from $1=$ no benefit to $4=$ great benefit on a 4-point Likert-type scale. Organizational-based costs of participation were measured by respondent agreement on 11 items. Examples include: coalition activities do not reach my primary constituency, the coalition is not taking meaningful action, the financial burden of traveling to coalition meetings is too high, and the coalition is competing with my organization. Response options ranked from $1=$ strongly disagree to $4=$ strongly agree on a 4 -point Likerttype scale. One question gauged participation from an organizational perspective by asking 
respondents if the benefits of participation outweigh the costs at this point. If the respondent represented an organization, response options were yes, no or don't know. One question gauged personal participation perspective by asking respondents if the benefits of participation outweigh the costs at this point. Response options were yes, no or don't know.

\section{Data Analysis}

CSAS responses from twelve coalitions were aggregated and analyzed using IBM SPSS Statistics 21.0 for Microsoft Windows 7. Demographic variables were examined descriptively to find means, medians, and frequencies of the sample population. Sector representation was described by assigning a value of 1 to each organization indicated as coalition participants, and summing the responses. Possible values for the frequency of sector representation ranged from 0 to 30. Bivariate analyses were performed to determine relationships between dependent and independent variables. Because our research question focused on outcomes at the coalition level, data were not coded to individual members and could not be paired between the time points. Samples were considered independent. Relationships between categorical variables were analyzed using Pearson's chi-square tests for independence where significance was established at $\mathrm{p}<0.05$. Secondly, because Likert-type scales are ordinal, and the data does not approximate a normal distribution, parametric tests could not be used to compare means and standard deviations between groups. Due to these reasons, relationships between Likert-type scale data were evaluated using Mann-Whitney $U$ tests where significance was set at $p<0.05$. These tests were run three times to examine the relationships between variables at baseline and follow-up, and between intervention and control groups. Variables were grouped as follows: intervention coalition at baseline and follow-up, control coalition at baseline and follow-up, and both intervention and control coalitions at follow-up. 


\section{Chapter 3 - Results}

\section{Demographics and Sector Representation}

At baseline, 133 community coalition members (76 from intervention coalitions and 57 from control coalitions) completed the CSAS in six states. One year later, 113 community coalition members completed the CSAS (71 from intervention coalitions and 42 from control coalitions). Of the members completing the survey during the follow-up period, $60.6 \%$ of members in the intervention group and $64.3 \%$ of members in the control group reported they had completed the initial CSAS. Respondents were predominantly white females, with non-white representation in only two coalitions. Most (17/24) coalitions had at least one male member, and the majority $(85.8 \%)$ of coalition members had a college-level degree or higher.

Provided a list of 30 different organization types, the majority ( $\mathrm{n} \geq 10)$ of respondents identified with the following community groups : local health department $(n=33)$, hospital $(n=29)$, day care/preschool/head start center $(n=24)$, academic institution (college/university) $(n=21)$, other community-based organization $(n=19)$, school (any grades K-12) $(n=18)$, and community health center/community clinic $(n=13)$. 
Table 3.1 Description of coalition demographics

\begin{tabular}{|c|c|c|c|c|}
\hline Variables & Control Baseline & Control Follow-up & Intervention Baseline & Intervention Follow-up \\
\hline $\mathbf{N}$ & 57 & 42 & 76 & 71 \\
\hline \multicolumn{5}{|l|}{ Gender } \\
\hline Male & $14 \%$ & $9.5 \%$ & $17.1 \%$ & $12.7 \%$ \\
\hline Female & $82.5 \%$ & $90.5 \%$ & $81.6 \%$ & $84.5 \%$ \\
\hline Age & $\begin{array}{l}47.09(\mathrm{SD}=12.72, \\
\text { Range }=23-77)\end{array}$ & $\begin{array}{l}47.66(\mathrm{SD}=12.90, \\
\text { Range }=13-68)\end{array}$ & $\begin{array}{l}46.78(\mathrm{SD}=11.79, \\
\text { Range }=23-73)\end{array}$ & $\begin{array}{l}47.70(\mathrm{SD}=10.64, \\
\text { Range }=26-73)\end{array}$ \\
\hline \multicolumn{5}{|l|}{ Race/Ethnicity } \\
\hline African American & $5.3 \%$ & $2.4 \%$ & ----- & ----- \\
\hline Caucasian & $89.5 \%$ & $97.6 \%$ & $98.7 \%$ & $100 \%$ \\
\hline Latino or Hispanic & ----- & $2.4 \%$ & ----- & ----- \\
\hline \multicolumn{5}{|l|}{ Education } \\
\hline$\leq$ Grade 8 & ----- & $2.4 \%$ & ----- & ----- \\
\hline High school & $7 \%$ & $4.8 \%$ & $3.9 \%$ & $9.9 \%$ \\
\hline Tech or Vocational & $1.8 \%$ & $4.8 \%$ & $6.6 \%$ & $8.5 \%$ \\
\hline College & $57.9 \%$ & $50 \%$ & $50 \%$ & $45.1 \%$ \\
\hline Graduate School & $29.8 \%$ & $35.7 \%$ & $38.2 \%$ & $36.6 \%$ \\
\hline $\begin{array}{l}\text { Community Sector } \\
\text { Representation }\end{array}$ & 14 & 11 & 17 & 17 \\
\hline
\end{tabular}

\section{Coalition Membership}

\section{Recruitment}

In the intervention group, significant progress in some recruitment variables was noted between baseline and follow-up. This was not true of the control group. In the intervention coalition, $70.4 \%$ of members indicated that groups, organizations, and/or schools were sufficiently represented in the coalition at follow-up, which was significantly more than the $46.1 \%$ indicated at baseline. $66.2 \%$ of the coalition members in the intervention group reported that their coalitions were actively recruiting new participants, which was significant in comparison to the $40.5 \%$ of members in the control group that reported active recruitment. When asked to discuss the lack of progress, $11.9 \%$ of control coalition members disclosed a lack of 
involvement from the community sector due to "drop out;" no members from the intervention group reported that variable.

\section{Figure 3.1 Group differences between coalition member opinion of organizational capabilities}

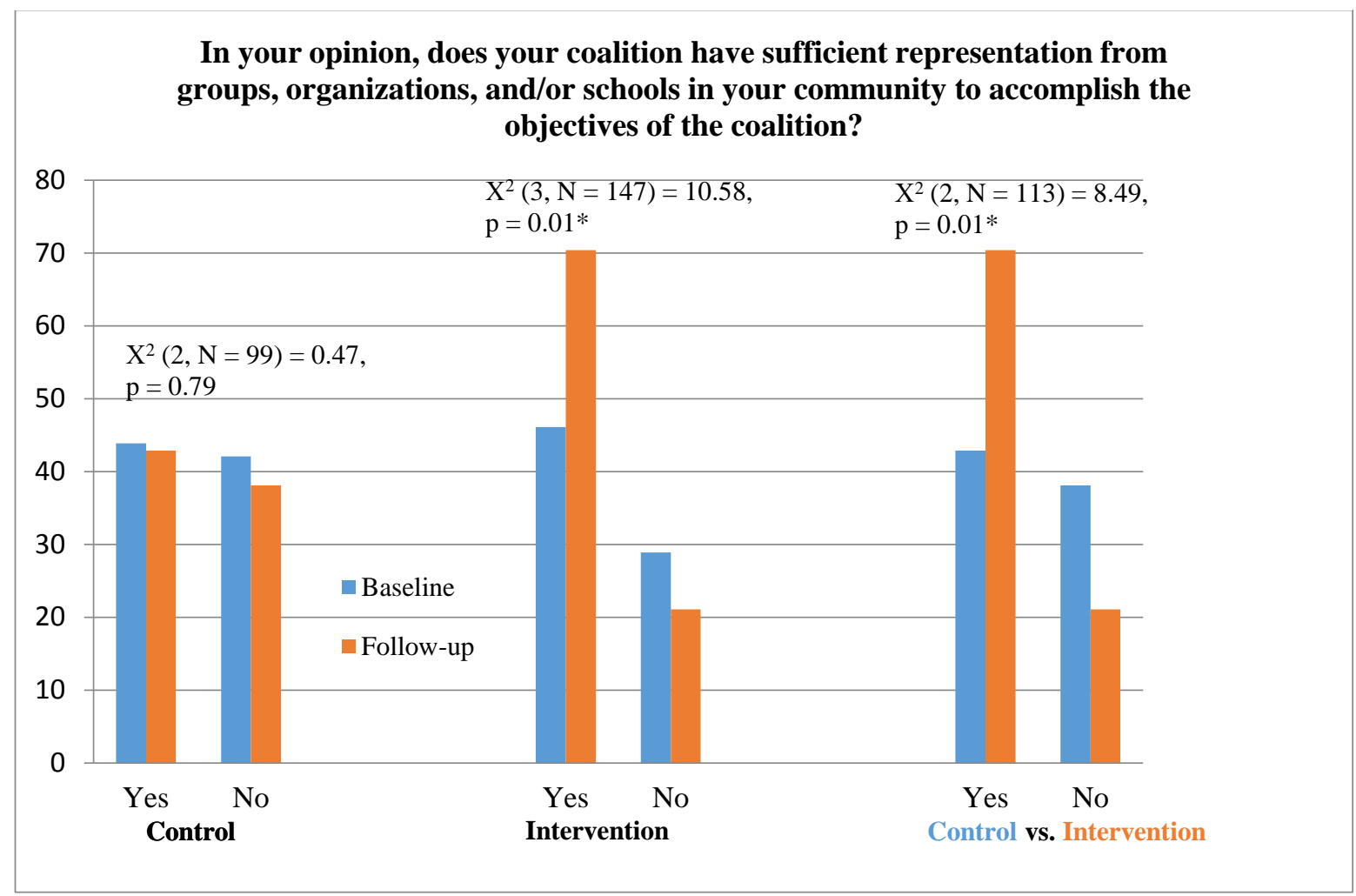

*Significant, $\mathrm{p}<0.05$

Table 3.2 Chi-square analysis of recruitment variables

\begin{tabular}{|c|c|c|c|}
\hline Recruitment Measure & Control & Intervention & $\begin{array}{l}\text { Control vs. } \\
\text { Intervention }\end{array}$ \\
\hline \multicolumn{4}{|l|}{ Reasons indicated for a lack of organization-specific representation: } \\
\hline The coalition never tried to involve them & $0.98, p=1.00$ & $2.41, p=0.16$ & $0.10, p=0.75$ \\
\hline The coalition invited them but they chose not to participate & $0.58, p=0.77$ & $0.23, p=0.63$ & $1.42, p=0.23$ \\
\hline They used to participate but dropped out & $0.23, p=0.28$ & $1.89, p=0.17$ & $8.84, p=0.003$ \\
\hline The coalition cannot get access to representatives of this group & $0.74, p=0.39$ & $0.28, p=0.60$ & $1.82, p=0.18$ \\
\hline The coalition as a whole is not sure that this group should be asked to join & $0.05, p=0.83$ & $0.94, p=0.33$ & $1.71, p=0.19$ \\
\hline Resources are lacking to recruit new members & $0.01, p=0.91$ & $0.28, p=0.59$ & $0.02, p=0.89$ \\
\hline Some coalition members do not want to share power with this group & $1.37, p=0.24$ & $0.94, p=0.33$ & $1.71, p=0.19$ \\
\hline Don't know & $0.43, p=0.51$ & $0.64, p=0.42$ & $1.31, p=0.25$ \\
\hline Is your coalition actively recruiting new members? & $3.70, p=0.16$ & $13.13, p=0.004$ & $11.15, p=0.01$ \\
\hline $\begin{array}{l}\text { In your opinion, do new members receive adequate orientation to be effective } \\
\text { members of the coalition? }\end{array}$ & $1.17, p=0.76$ & $3.15, p=0.37$ & $0.84, p=0.84$ \\
\hline
\end{tabular}

Significant measures, $\mathrm{p}<0.05$, are shaded gray 


\section{Member Resources}

No changes in membership measures were observed in any group

Table 3.3 Mann-Whitney $U$ tests for membership variables

\begin{tabular}{|l|l|l|l|}
\hline Membership Measure & \multicolumn{1}{|c|}{ Control } & \multicolumn{1}{c|}{ Intervention } & \multicolumn{1}{c|}{ Control vs. Intervention } \\
\hline $\begin{array}{l}\text { Please circle the number which best represents your opinion about } \\
\text { the percentage of members who participate in your coalition who } \\
\text { have enough authority to make commitments of resources or } \\
\text { other support for the coalition. }\end{array}$ & $826.54 / 41.24$ & $55.78 / 58.24$ & $45.07 / 49.15$ \\
\hline
\end{tabular}

\section{Coalition Systems}

\section{Decision-Making}

Significant changes in decision-making variables were observed for all comparison groups between baseline and follow-up. In both control and intervention groups, member knowledge of the decision-making process (regarding coalition priorities, policies, and actions) increased. This change was manifested by fewer members selecting that they "don't know" how decisions are usually made in the coalition. In the control group, Mann-Whitney $\mathrm{U}$ tests indicated that personal influence in making coalition decisions was higher at follow-up than at baseline. In the intervention group, $68.4 \%$ of coalition members indicated that the principal rationale behind decisions shifted toward "coalition members vote, with majority rule;" this was significantly higher than the same measure at baseline (31.6\%). Intervention coalition members also indicated that they became more comfortable with the decision-making process at follow-up and that the process had become more clear and explicit. Comparison of the two groups revealed that intervention coalition members were more likely than their counterparts in the control group to affirm that their organization followed standard decision-making procedures. 
Table 3.4 Chi-square analysis of decision-making variables

\begin{tabular}{|l|l|l|l|}
\hline Decision-making Measure & \multicolumn{1}{|c|}{ Control } & \multicolumn{1}{|c|}{ Intervention } & \multicolumn{1}{c|}{ Control vs. Intervention } \\
\hline $\begin{array}{l}\text { How are decisions usually made regarding coalition } \\
\text { priorities, policies and actions? }\end{array}$ & & & \\
$\quad \begin{array}{l}\text { Coalition members vote, with majority rule } \\
\text { Coalition members discuss the issue and come to consensus }\end{array}$ & $3.31, p=0.07$ & $2.29, p=0.13$ & $0.16, p=0.69$ \\
The coalition chair makes final decisions & $0.05, p=0.83$ & $0.002, p=0.96$ & $0.14, p=0.71$ \\
$\begin{array}{l}\text { The coalition executive or steering committee makes final } \\
\text { decisions }\end{array}$ & $0.74, p=0.39$ & $0.09, p=0.77$ & $1.82, p=0.18$ \\
The lead agency for the project makes the decisions & $1.08, p=0.30$ & $2.08, p=0.15$ & $0.66, p=0.42$ \\
Don't know & $8.31, p=0.004$ & $10.23, p=0.001$ & $0.02, p=0.89$ \\
\hline
\end{tabular}

Significant measures, $\mathrm{p}<0.05$, are shaded gray

Table 3.5 Mann-Whitney rank tests for decision-making variables

\begin{tabular}{|c|c|c|c|}
\hline Decision-making Measure & Control & Intervention & Control vs. Intervention \\
\hline \multicolumn{4}{|l|}{$\begin{array}{l}\text { Rank how much influence you think the person or } \\
\text { group has in deciding on the actions and policies for } \\
\text { your coalition }\end{array}$} \\
\hline Coalition Chair & $\begin{array}{l}41.67 / 45.82 \\
824.00, \mathrm{p}=0.33\end{array}$ & $\begin{array}{l}63.65 / 66.37 \\
1992.50, p=0.60\end{array}$ & $\begin{array}{l}52.42 / 50.95 \\
1181.00, \mathrm{p}=0.75\end{array}$ \\
\hline Officers or Committee Chairs & $\begin{array}{l}38.63 / 39.50 \\
709.50, \mathrm{p}=0.84\end{array}$ & $\begin{array}{l}61.42 / 59.67 \\
1743.00, p=0.73\end{array}$ & $\begin{array}{l}47.55 / 49.00 \\
1008.00, p=0.77\end{array}$ \\
\hline Lead Staff & $\begin{array}{l}33.72 / 35.44 \\
544.5, \mathrm{p}=0.67\end{array}$ & $\begin{array}{l}58.50 / 56.50 \\
1567.50, p=0.70\end{array}$ & $\begin{array}{l}44.89 / 44.29 \\
871.5, p=0.90\end{array}$ \\
\hline Coalition Members & $\begin{array}{l}44.85 / 46.31 \\
967.50, p=0.76\end{array}$ & $\begin{array}{l}68.89 / 65.08 \\
2084.50, p=0.51\end{array}$ & $\begin{array}{l}55.81 / 52.10 \\
1227.50, p=0.48\end{array}$ \\
\hline $\begin{array}{l}\text { Rank how much influence you personally have in } \\
\text { making coalition decisions }\end{array}$ & $\begin{array}{l}41.41 / 50.85 \\
786.00, \mathrm{p}=0.05\end{array}$ & $\begin{array}{l}67.43 / 70.60 \\
2237.5, p=0.51\end{array}$ & $\begin{array}{l}58.78 / 51.26 \\
1139.50, \mathrm{p}=0.14\end{array}$ \\
\hline $\begin{array}{l}\text { Rank how comfortable you are overall with the } \\
\text { coalition decision-making process. }\end{array}$ & $\begin{array}{l}43.69 / 48.82 \\
909.50, p=0.22\end{array}$ & $\begin{array}{l}59.23 / 80.07 \\
1661.00, \mathrm{p}=0.00\end{array}$ & $\begin{array}{l}53.37 / 55.99 \\
1327.00, \mathrm{p}=0.52\end{array}$ \\
\hline \multicolumn{4}{|l|}{$\begin{array}{l}\text { How much to you agree or disagree with the following } \\
\text { statements }\end{array}$} \\
\hline $\begin{array}{l}\text { The coalition has clear and explicit procedures for making } \\
\text { important decisions }\end{array}$ & $\begin{array}{l}39.55 / 37.27 \\
674.50, \mathrm{p}=0.61\end{array}$ & $\begin{array}{l}53.67 / 66.48 \\
1409.50, p=0.02\end{array}$ & $\begin{array}{l}46.74 / 51.78 \\
1006.00, p=0.33\end{array}$ \\
\hline $\begin{array}{l}\text { The coalition follows standard procedures for making } \\
\text { decisions }\end{array}$ & $\begin{array}{l}39.14 / 38.85 \\
734.5, p=0.95\end{array}$ & $\begin{array}{l}57.71 / 66.85 \\
1635.00, p=0.08\end{array}$ & $\begin{array}{l}44.84 / 55.29 \\
956.00, p=0.04\end{array}$ \\
\hline $\begin{array}{l}\text { The decision-making process used by the coalition is fair } \\
\text { The decision-making process used by the coalition is } \\
\text { timely }\end{array}$ & $\begin{array}{l}36.56 / 40.65 \\
642.5, \mathrm{p}=0.35 \\
35.38 / 41.00 \\
595.00, \mathrm{p}=0.21\end{array}$ & $\begin{array}{l}61.25 / 65.55 \\
1845.00, \mathrm{p}=0.43 \\
57.82 / 61.88 \\
1640.00, \mathrm{p}=0.44\end{array}$ & $\begin{array}{l}55.18 / 49.49 \\
1055.50, \mathrm{p}=0.28 \\
52.57 / 48.59 \\
1030.00, \mathrm{p}=0.45\end{array}$ \\
\hline The coalition makes good decisions & $\begin{array}{l}41.43 / 37.47 \\
683.00, p=0.38\end{array}$ & $\begin{array}{l}59.19 / 64.42 \\
1721.00, p=0.34\end{array}$ & $\begin{array}{l}50.38 / 53.72 \\
1173.50, p=0.54\end{array}$ \\
\hline
\end{tabular}

Significant measures, $\mathrm{p}<0.05$, are shaded gray 


\section{Conflict Resolution}

Some factors shown to cause conflict were found to be lower at follow-up in all comparison groups. In the control coalitions, "differences in opinion about the best strategies to achieve coalition goals" caused significantly less conflict at follow-up. In the intervention group, "differences in opinion about the coalition mission, goals and objectives," "procedures used for completing work," and "members not being sufficiently included in coalition processes/decision making" caused less conflict in the coalition at follow-up than at baseline. All of these differences were statistically significant. When the study groups were compared at follow-up, intervention coalitions identified "differences in opinion about the best strategies to achieve coalition goals," and "personality clashes" as causing conflict within their coalitions more often than in control coalitions. However, these same measures were not significant between baseline and follow-up in the intervention group, suggesting that there were no negative changes within the intervention group.

At follow-up, fewer members in the control group indicated that they "don't know" the main strategy that their coalition employs to address conflicts. Additionally, more control coalition members indicated that their coalition addressed conflict through "open dialogue about opposing viewpoints" at follow-up, and fewer indicated that conflict was addressed by "postponing or avoiding discussions of controversial issues." 
Table 3.6 Chi-square analysis of coalition conflict

\begin{tabular}{|c|c|c|c|}
\hline Conflict Measure & Control & Intervention & Control vs. Intervention \\
\hline Indicate the amount of conflict in your coalition & $1.21, \mathrm{p}=0.75$ & $2.05, p=0.56$ & $1.13, \mathrm{p}=0.77$ \\
\hline \multicolumn{4}{|l|}{$\begin{array}{l}\text { Please choose the main strategy you coalition used to address } \\
\text { conflicts that occur }\end{array}$} \\
\hline Open dialogue about opposing viewpoints & $8.34, p=0.004$ & $0.44, p=0.51$ & $2.42, \mathrm{p}=0.12$ \\
\hline Postponing or avoiding discussions of controversial issues & $3.88, p=0.05$ & $0.20, p=0.65$ & $3.10, p=0.80$ \\
\hline $\begin{array}{l}\text { Having a third party mediate between those with opposing } \\
\text { viewpoints }\end{array}$ & $0.74, p=0.39$ & $0.01, p=0.93$ & $1.82, p=0.18$ \\
\hline Having the opposing parties negotiate directly with each other & $0.05, p=0.83$ & $0.86, p=0.35$ & $0.26, p=0.61$ \\
\hline One party to the conflict gives in & $0.75, \mathrm{p}=0.39$ & $1.89, \mathrm{p}=0.17$ & ---- \\
\hline Don’t know & $7.28, p=0.01$ & $0.22, p=0.64$ & $1.52, \mathrm{p}=0.22$ \\
\hline
\end{tabular}

Significant measures, $\mathrm{p}<0.05$, are shaded gray

Table 3.7 Mann-Whitney rank tests of conflict variables

\begin{tabular}{|c|c|c|c|}
\hline $\begin{array}{c}\text { Conflict Measure } \\
\end{array}$ & Control & Intervention & Control vs. Intervention \\
\hline \multicolumn{4}{|l|}{$\begin{array}{l}\text { Rank how much conflict within the coalition was } \\
\text { caused by each of the following factors }\end{array}$} \\
\hline $\begin{array}{l}\text { Differences in opinion about coalition mission and } \\
\text { goals coalition goals and objectives }\end{array}$ & $\begin{array}{l}37.55 / 34.21 \\
568.00, \mathrm{p}=0.36\end{array}$ & $\begin{array}{l}60.61 / 50.92 \\
1242.50, p=0.05\end{array}$ & $\begin{array}{l}44.15 / 47.05 \\
896.00, p=0.49\end{array}$ \\
\hline Differences in opinion about specific objectives & $\begin{array}{l}40.09 / 32.49 \\
509.50, \mathrm{p}=0.06\end{array}$ & $\begin{array}{l}59.88 / 53.24 \\
1381.50, \mathrm{p}=0.22\end{array}$ & $\begin{array}{l}41.43 / 48.73 \\
813.50, p=0.12\end{array}$ \\
\hline $\begin{array}{l}\text { Differences in opinion about the best strategies to } \\
\text { achieve }\end{array}$ & $\begin{array}{l}39.84 / 31.82 \\
487.00, \mathrm{p}=0.046\end{array}$ & $\begin{array}{l}58.35 / 54.84 \\
1465.50, \mathrm{p}=0.51\end{array}$ & $\begin{array}{l}39.49 / 51.33 \\
747.50, \mathrm{p}=0.02\end{array}$ \\
\hline Personality clashes & $\begin{array}{l}37.90 / 35.91 \\
624.00, p=0.55\end{array}$ & $\begin{array}{l}53.29 / 56.74 \\
1391.00, \mathrm{p}=0.49\end{array}$ & $\begin{array}{l}38.24 / 47.52 \\
701.00, p=0.04\end{array}$ \\
\hline Fighting for power, prestige and/or influence & $\begin{array}{l}36.33 / 37.76 \\
637.00, p=0.57\end{array}$ & $\begin{array}{l}59.58 / 57.49 \\
1619.50, \mathrm{p}=0.61\end{array}$ & $\begin{array}{l}46.43 / 48.11 \\
983.50, p=0.63\end{array}$ \\
\hline Fighting for resources & $\begin{array}{l}36.18 / 36.85 \\
634.00, p=0.83\end{array}$ & $\begin{array}{l}56.60 / 56.40 \\
1562.0, p=0.97\end{array}$ & $\begin{array}{l}42.91 / 47.84 \\
864.00, p=0.25\end{array}$ \\
\hline $\begin{array}{l}\text { Differences in opinion about who gets public } \\
\text { exposure and recognition }\end{array}$ & $\begin{array}{l}35.45 / 38.69 \\
606.00, p=0.14\end{array}$ & $\begin{array}{l}59.93 / 57.21 \\
1599.00, \mathrm{p}=0.41\end{array}$ & $\begin{array}{l}49.56 / 47.89 \\
1030.50, p=0.58\end{array}$ \\
\hline Procedures used for completing the work & $\begin{array}{l}38.12 / 35.72 \\
619.50, p=0.55\end{array}$ & $\begin{array}{l}60.55 / 48.67 \\
1137.00, p=0.02\end{array}$ & $\begin{array}{l}46.46 / 44.10 \\
885.50, p=0.57\end{array}$ \\
\hline $\begin{array}{l}\text { People aren't sufficiently included in coalition } \\
\text { processes/decision making }\end{array}$ & $\begin{array}{l}38.73 / 36.06 \\
631.00, p=0.48\end{array}$ & $\begin{array}{l}61.81 / 51.55 \\
1279.00, \mathrm{p}=0.02\end{array}$ & $\begin{array}{l}48.87 / 45.11 \\
905.50, p=0.30\end{array}$ \\
\hline $\begin{array}{l}\text { Member(s) who dominate the coalition meetings } \\
\text { and impede proper collaboration }\end{array}$ & $\begin{array}{l}37.98 / 36.94 \\
661.00, p=0.73\end{array}$ & $\begin{array}{l}58.25 / 58.75 \\
1667.00, p=0.91\end{array}$ & $\begin{array}{l}43.56 / 48.98 \\
886.00, p=0.17\end{array}$ \\
\hline
\end{tabular}

Significant measures, $\mathrm{p}<0.05$, are shaded gray

\section{Leadership}

Change in leadership measures was observed more often in the intervention group. Level of respect for coalition leadership increased both in the community and the coalition from baseline to follow-up in the intervention group, and more members agreed that their leaders were 
able to build consensus on key decisions, work collaboratively within the coalition, and keep the organization focused on tasks and objectives. In the control group, the only measure of improvement was that the leadership advocated strongly for their opinions and agenda less often at follow-up than at baseline. No significant differences were found between intervention and control groups at follow-up.

Table 3.8 Mann-Whitney rank tests of leadership variables

\begin{tabular}{|c|c|c|c|}
\hline Leadership Measure & Control & Intervention & Control vs. Intervention \\
\hline $\begin{array}{l}\text { "The leadership of our coalition..." } \\
\text { Has a clear vision for the coalition }\end{array}$ & $\begin{array}{l}40.75 / 46.97 \\
780.00, p=0.20\end{array}$ & $\begin{array}{l}60.63 / 69.44 \\
1796.00, p=0.13\end{array}$ & $\begin{array}{l}49.97 / 52.59 \\
1146.50, p=0.59\end{array}$ \\
\hline Is respected in the community & $\begin{array}{l}42.83 / 43.21 \\
889.00, \mathrm{p}=0.94\end{array}$ & $\begin{array}{l}57013 / 68.04 \\
1538.50, \mathrm{p}=0.05\end{array}$ & $\begin{array}{l}46.12 / 53.30 \\
1018.50, \mathrm{p}=0.16\end{array}$ \\
\hline Gets things done & $\begin{array}{l}42.81 / 44.33 \\
884.00, \mathrm{p}=0.75\end{array}$ & $\begin{array}{l}57.46 / 68.28 \\
1614.00, p=0.06\end{array}$ & $\begin{array}{l}50.33 / 53.02 \\
1183.00, \mathrm{p}=0.62\end{array}$ \\
\hline Is respected in the coalition & $\begin{array}{l}42.91 / 43.10 \\
896.00, p=0.97\end{array}$ & $\begin{array}{l}57.83 / 74.55 \\
1569.50, p=0.003\end{array}$ & $\begin{array}{l}47.60 / 55.56 \\
1084.00, \mathrm{p}=0.11\end{array}$ \\
\hline Controls decisions & $\begin{array}{l}39.88 / 41.22 \\
769.00, \mathrm{p}=0.79\end{array}$ & $\begin{array}{l}54.16 / 62.84 \\
1430.50, p=0.14\end{array}$ & $\begin{array}{l}45.50 / 49.59 \\
980.50, p=0.45\end{array}$ \\
\hline Intentionally seeks other's views & $\begin{array}{l}42.15 / 40.75 \\
807.50, p=0.76\end{array}$ & $\begin{array}{l}58.38 / 66.89 \\
1656.50, p=0.13\end{array}$ & $\begin{array}{l}45.25 / 52.19 \\
978.50, \mathrm{p}=0.17\end{array}$ \\
\hline $\begin{array}{l}\text { Utilizes the skills and talents of many, not just a } \\
\text { few }\end{array}$ & $\begin{array}{l}41.30 / 42.83 \\
823.50, p=0.74\end{array}$ & $\begin{array}{l}59.00 / 68.77 \\
1705.00, p=0.08\end{array}$ & $\begin{array}{l}49.96 / 53.19 \\
1157.50, \mathrm{p}=0.53\end{array}$ \\
\hline $\begin{array}{l}\text { Creates an appropriate balance of responsibility } \\
\text { between leaders, staff and members }\end{array}$ & $\begin{array}{l}37.23 / 41.24 \\
655.00, \mathrm{p}=0.34\end{array}$ & $\begin{array}{l}52.72 / 31.80 \\
1362.00, p=0.10\end{array}$ & $\begin{array}{l}47.62 / 47.43 \\
1016.00, \mathrm{p}=0.97\end{array}$ \\
\hline $\begin{array}{l}\text { Advocates strongly for its own opinions and } \\
\text { Agendas }\end{array}$ & $\begin{array}{l}45.44 / 35.97 \\
626.00, p=0.05\end{array}$ & $\begin{array}{l}61.24 / 64.79 \\
1842.00, p=0.55\end{array}$ & $\begin{array}{l}48.49 / 51.73 \\
1101.50, \mathrm{p}=0.56\end{array}$ \\
\hline Builds consensus on key decisions & $\begin{array}{l}40.21 / 42.92 \\
783.00, p=0.56\end{array}$ & $\begin{array}{l}55.88 / 68.71 \\
1522.50, p=0.02\end{array}$ & $\begin{array}{l}49.05 / 53.80 \\
1133.00, \mathrm{p}=0.37\end{array}$ \\
\hline Works collaboratively with coalition & $\begin{array}{l}42.07 / 39.79 \\
771.00, \mathrm{p}=0.62\end{array}$ & $\begin{array}{l}58.70 / 72.09 \\
1677.00, p=0.02\end{array}$ & $\begin{array}{l}49.87 / 54.02 \\
1154.00, \mathrm{p}=0.43\end{array}$ \\
\hline Keeps the coalition focused on tasks and objectives & $\begin{array}{l}43.14 / 41.80 \\
852.00, p=0.79\end{array}$ & $\begin{array}{l}57.12 / 69.68 \\
1588.50, p=0.03\end{array}$ & $\begin{array}{l}48.04 / 55.29 \\
1101.50, \mathrm{p}=0.18\end{array}$ \\
\hline Is skillful in resolving conflict & $\begin{array}{l}35.95 / 39.53 \\
607.00, p=0.43\end{array}$ & $\begin{array}{l}53.20 / 54.79 \\
1388.50, p=0.77\end{array}$ & $\begin{array}{l}47.09 / 41.37 \\
749.00, \mathrm{p}=0.25\end{array}$ \\
\hline Is ethical & $\begin{array}{l}41.70 / 42.33 \\
847.00, p=0.89\end{array}$ & $\begin{array}{l}65.65 / 65.36 \\
2101.00, p=0.96\end{array}$ & $\begin{array}{l}50.88 / 55.87 \\
1215.00, p=0.35\end{array}$ \\
\hline
\end{tabular}

Significant measures, $\mathrm{p}<0.05$, are shaded gray 


\section{Staffing}

As with leadership, change in variables that assess staffing was noted more frequently in the intervention group. Intervention group members were more likely to agree that their coalition was well-managed at follow-up compared to baseline. More members from the intervention group also agreed that the role of staff was better understood. Within the control group, knowledge of who sets the meeting agenda increased, with fewer members selecting that they “don't know." No significant differences in staffing variables were found when intervention and control groups were compared at follow-up.

Table 3.9 Chi-square analysis of coalition staffing variables

\begin{tabular}{|l|l|l|l|}
\hline Staffing Measure & \multicolumn{1}{|c|}{ Control } & \multicolumn{1}{|c|}{ Intervention } & \multicolumn{1}{|c|}{ Control vs. Intervention } \\
\hline $\begin{array}{l}\text { Indicate who sets the agenda for meetings } \\
\quad \text { Coalition Chair }\end{array}$ & $1.51, \mathrm{p}=0.28$ & $0.55, \mathrm{p}=0.82$ & $0.32, \mathrm{p}=0.57$ \\
$\quad \begin{array}{l}\text { Officers or Committee Chairs } \\
\text { Lead Staff }\end{array}$ & $0.07, \mathrm{p}=0.79$ & $2.66, \mathrm{p}=0.10$ & $0.40, \mathrm{p}=0.53$ \\
$\quad$ Coalition Members & $0.30, \mathrm{p}=0.35$ & $0.05, \mathrm{p}=0.82$ & $0.86, \mathrm{p}=0.35$ \\
$\quad$ Don't know & $4.38, \mathrm{p}=0.04$ & $2.66, \mathrm{p}=0.10$ & $0.03, \mathrm{p}=0.87$ \\
& & $0.38, \mathrm{p}=0.54$ & $2.71, \mathrm{p}=0.10$ \\
\hline Rank by level of agreement... & $47.84 / 51.80$ & $58.15 / 70.10$ & $54.93 / 55.04$ \\
The coalition is well managed & $1074.00, \mathrm{p}=0.46$ & $1659.00, \mathrm{p}=0.03$ & $1391.00, \mathrm{p}=0.98$ \\
& $43.56 / 47.56$ & $40.26 / 49.05$ & $43.59 / 38.44$ \\
The work of the paid staff supports the work of the coalition & $830.00, \mathrm{p}=0.47$ & $789.50, \mathrm{p}=0.07$ & $669.00, \mathrm{p}=0.30$ \\
& $42.13 / 48.85$ & $40.02 / 51.23$ & $43.02 / 34.47$ \\
People know the roles of staff as compared to coalition & $748.50, \mathrm{p}=0.22$ & $760.00, \mathrm{p}=0.03$ & $526.50, \mathrm{p}=0.08$ \\
members & $47.53 / 52.24$ & $63.08 / 65.72$ & $59.39 / 53.19$ \\
Coalition members take responsibility & $1056.00, \mathrm{p}=0.38$ & $1951.50, \mathrm{p}=0.62$ & $1255.00, \mathrm{p}=0.26$ \\
\hline
\end{tabular}

Significant measures, $\mathrm{p}<0.05$, are shaded gray

\section{Trust}

Variables assessing trust showed minimally positive changes. At follow-up, intervention group coalition members were more likely to agree that they "respect each others' points of view even if they might disagree." 
Table 3.10 Mann-Whitney rank tests for coalition trust variables

\begin{tabular}{|c|c|c|c|}
\hline Trust Measure & Control & Intervention & Control vs. Intervention \\
\hline \multicolumn{4}{|l|}{ Rank by level of agreement... } \\
\hline $\begin{array}{l}\text { Relationships among coalition members go } \\
\text { beyond individuals at the table, to include } \\
\text { member organizations }\end{array}$ & $\begin{array}{l}44.39 / 42.48 \\
879.00, p=0.69\end{array}$ & $\begin{array}{l}60.98 / 71.54 \\
1825.50, \mathrm{p}=0.06\end{array}$ & $\begin{array}{l}54.56 / 55.25 \\
1362.50, \mathrm{p}=0.90\end{array}$ \\
\hline $\begin{array}{l}\text { I am comfortable requesting assistance from the } \\
\text { other coalition members when I feel their input } \\
\text { could be of value }\end{array}$ & $\begin{array}{l}43.20 / 48.13 \\
897.50, p=0.31\end{array}$ & $\begin{array}{l}64.48 / 72.41 \\
2042.00, p=0.18\end{array}$ & $\begin{array}{l}56.57 / 55.65 \\
1425.00, \mathrm{p}=0.87\end{array}$ \\
\hline $\begin{array}{l}\text { I can talk openly and honestly at the coalition } \\
\text { meeting }\end{array}$ & $\begin{array}{l}45.49 / 46.60 \\
1004.00, p=0.82\end{array}$ & $\begin{array}{l}65.69 / 73.09 \\
2123.50, p=0.22\end{array}$ & $\begin{array}{l}58.12 / 56.34 \\
1444.00, \mathrm{p}=0.75\end{array}$ \\
\hline $\begin{array}{l}\text { I am comfortable expressing my point of view } \\
\text { even if they might disagree }\end{array}$ & $\begin{array}{l}44.81 / 46.29 \\
975.00, p=0.76\end{array}$ & $\begin{array}{l}68.97 / 70.99 \\
2344.00, p=0.74\end{array}$ & $\begin{array}{l}61.29 / 54.46 \\
1311.00, p=0.23\end{array}$ \\
\hline $\begin{array}{l}\text { I am comfortable bringing up new ideas at } \\
\text { coalition meetings }\end{array}$ & $\begin{array}{l}44.43 / 45.64 \\
960.00, p=0.80\end{array}$ & $\begin{array}{l}68.70 / 71.25 \\
2325.50, p=0.67\end{array}$ & $\begin{array}{l}60.21 / 55.10 \\
1356.00, p=0.36\end{array}$ \\
\hline $\begin{array}{l}\text { Coalition members respect each others' points } \\
\text { of view even if they might disagree }\end{array}$ & $\begin{array}{l}42.68 / 47.60 \\
878.00, p=0.30\end{array}$ & $\begin{array}{l}62.83 / 74.91 \\
1931.50, \mathrm{p}=0.04\end{array}$ & $\begin{array}{l}59.62 / 54.63 \\
1339.00, \mathrm{p}=0.37\end{array}$ \\
\hline $\begin{array}{l}\text { My opinion is listened to and considered } \\
\text { by other members }\end{array}$ & $\begin{array}{l}42.21 / 45.92 \\
864.00, p=0.43\end{array}$ & $\begin{array}{l}64.66 / 72.23 \\
2052.00, p=0.20\end{array}$ & $\begin{array}{l}61.44 / 52.69 \\
1220.50, \mathrm{p}=0.11\end{array}$ \\
\hline
\end{tabular}

Significant measures, $\mathrm{p}<0.05$, are shaded gray

\section{Communication}

Changes in coalition communication were only observed in the intervention group. At

follow-up, more members agreed that they can communicate among themselves as desired and

that the coalition utilizes effective communication strategies when engaging the broader public.

Table 3.11 Mann-Whitney $U$ tests for measures of coalition communication

\begin{tabular}{|l|l|l|l|}
\hline Communication Measure & \multicolumn{1}{|c|}{ Control } & \multicolumn{1}{|c|}{ Intervention } & Control vs. Intervention \\
\hline Rank by level of agreement... & & & \\
& & & \\
The current method for communication & $42.76 / 46.50$ & $62.26 / 71.40$ & $54.82 / 55.91$ \\
between coalition staff/leadership and its & $881.50, p=0.42$ & $1904.50, p=0.10$ & $1386.50, p=0.84$ \\
members is effective & & & \\
Members can communicate between & $43.23 / 47.16$ & $59.54 / 73.05$ & $57.41 / 52.79$ \\
themselves as necessary or desired & $893.50, p=0.41$ & $1730.50, p=0.02$ & $1243.50, p=0.39$ \\
The coalition staff facilitates communication & $37.61 / 38.47$ & $57.58 / 63.23$ & $51.50 / 46.85$ \\
between coalition members & $681.00, p=0.85$ & $1628.50, p=0.29$ & $952.00, p=0.37$ \\
The coalition staff effectively and efficiently & $43.40 / 41.46$ & $61.50 / 72.58$ & $51.19 / 54.07$ \\
notifies me of meetings, agenda items, etc. & $837.00, p=0.68$ & $1842.50, p=0.06$ & $1216.50, p=0.57$ \\
The coalition utilizes effective strategies to & $32.43 / 28.55$ & $49.53 / 60.30$ & $49.88 / 49.27$ \\
communicate with the broader public & $353.50, p=0.36$ & $1202.00, p=0.047$ & $1114.50, p=0.91$ \\
\hline
\end{tabular}

Significant measures, $\mathrm{p}<0.05$, are shaded gray 


\section{Coalition Capacity}

Statistically significant progress in perceived coalition success, readiness and sustainability was observed in the intervention group, but not in the control group. At follow-up, $90.1 \%$ of intervention group members perceived that their coalition had benefitted their communities (compared to $73.7 \%$ measured at baseline). Additionally, respondents in the intervention group indicated an increase in agreement that their coalition is "making progress in implementing the activities that have potential to improve childhood obesity" and that "improving health outcomes for children who are at risk of obesity" at follow-up. Member satisfaction within the coalition was also higher at follow-up than at baseline. When compared at follow-up, significantly more control than intervention group members agreed "one or a small number of people or agencies could make significant progress in pediatric obesity without the coalition.”

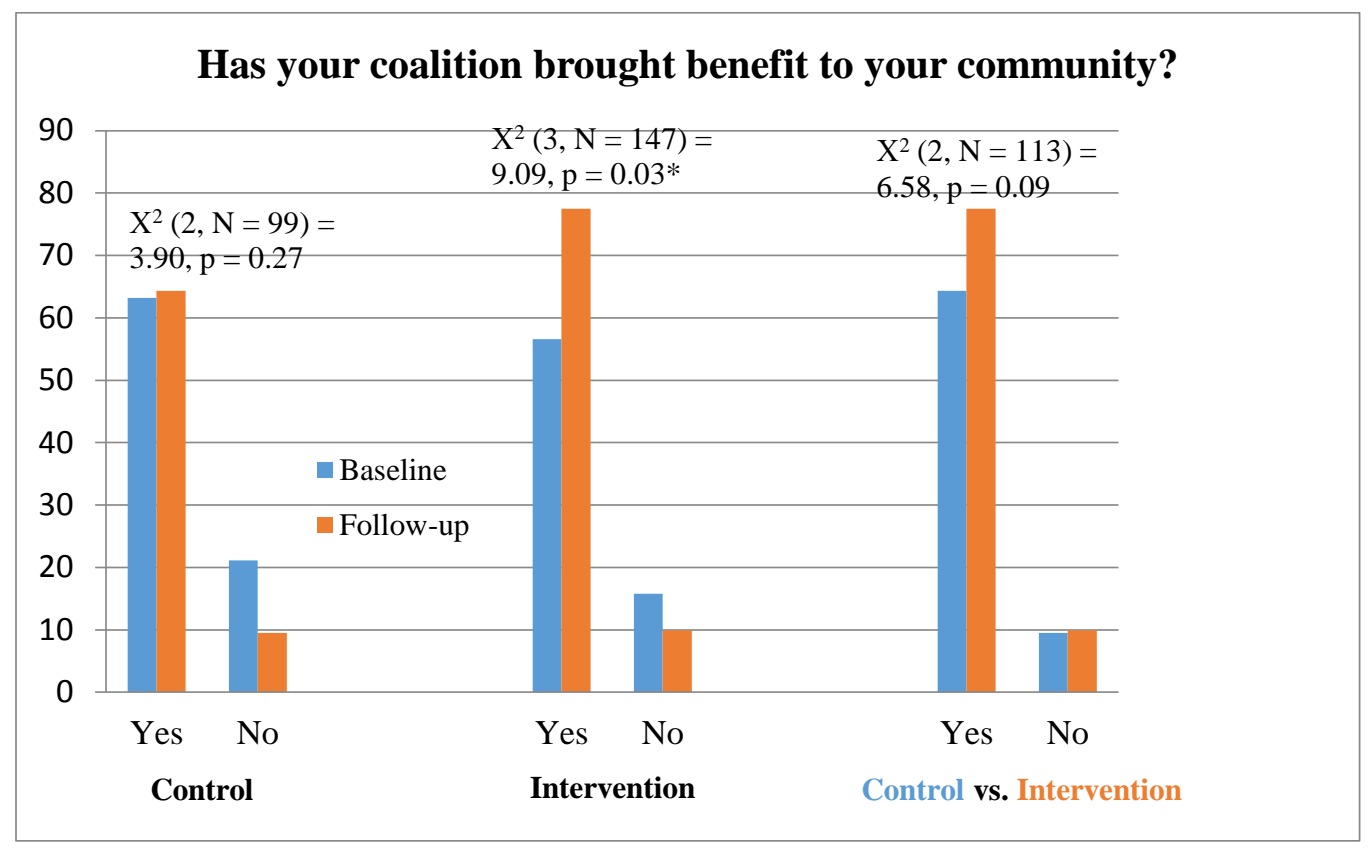

*Significant, $\mathrm{p}<0.05$

Figure 3.2 Group differences between coalition member opinion of coalition impact 
Table 3.12 Chi-square analysis of variables that gauge coalition capacity

\begin{tabular}{|l|c|c|c|}
\hline Health outcome-related knowledge & Control & Intervention & Control vs. Intervention \\
\hline $\begin{array}{l}\text { Do you feel you have adequate knowledge about childhood } \\
\text { obesity to function effectively in the coalition? }\end{array}$ & $4.42, \mathrm{p}=0.22$ & $4.16, \mathrm{p}=0.13$ & $2.58, \mathrm{p}=0.11$ \\
\hline $\begin{array}{l}\text { Has the coalition helped you learn more about childhood } \\
\text { obesity? }\end{array}$ & $5.01, \mathrm{p}=0.08$ & $3.69, \mathrm{p}=0.16$ & $3.55, \mathrm{p}=0.97$ \\
\hline Perceived coalition success & $2.31, \mathrm{p}=0.32$ & $7.10, \mathrm{p}=0.07$ & $1.93, \mathrm{p}=0.38$ \\
\hline $\begin{array}{l}\text { Has your coalition been responsible for activities or programs } \\
\text { that otherwise would not have occurred? }\end{array}$ &
\end{tabular}

Significant measures, $\mathrm{p}<0.05$, are shaded gray

Table 3.13 Mann-Whitney $U$ rank tests for coalition capacity measures

\begin{tabular}{|c|c|c|c|}
\hline Perceived coalition success & Control & Intervention & $\begin{array}{l}\text { Control vs. } \\
\text { Intervention }\end{array}$ \\
\hline \multicolumn{4}{|l|}{ Rank your level of agreement... } \\
\hline $\begin{array}{l}\text { The coalition is making progress in implementing the } \\
\text { activities that have potential to improve childhood obesity. }\end{array}$ & $\begin{array}{l}38.47 / 42.43 \\
720.50, p=0.36\end{array}$ & $\begin{array}{l}49.68 / 69.06 \\
0.44, p=0.03\end{array}$ & $\begin{array}{l}53.87 / 54.89 \\
1347.50, \mathrm{p}=0.85\end{array}$ \\
\hline $\begin{array}{l}\text { The coalition is improving health outcomes for children } \\
\text { who are at risk of obesity }\end{array}$ & $\begin{array}{l}33.00 / 38.76 \\
527.00, \mathrm{p}=0.17\end{array}$ & $\begin{array}{l}45.63 / 56.32 \\
0.20, p=0.32\end{array}$ & $\begin{array}{l}48.74 / 45.85 \\
971.50, p=0.54\end{array}$ \\
\hline \multicolumn{4}{|l|}{ Coalition readiness and sustainability } \\
\hline Rank your level of agreement... & & & \\
\hline $\begin{array}{l}\text { The coalition is making plans to continue operating after } \\
\text { current funding is terminated }\end{array}$ & $\begin{array}{l}31.37 / 27.50 \\
364.00, p=0.31\end{array}$ & $\begin{array}{l}36.77 / 32.71 \\
502.00, \mathrm{p}=0.32\end{array}$ & $\begin{array}{l}34.86 / 32.50 \\
494.00, p=0.56\end{array}$ \\
\hline $\begin{array}{l}\text { The coalition has begun to find resources to continue } \\
\text { operating after current funding is terminated }\end{array}$ & $\begin{array}{l}23.37 / 24.60 \\
261.50, p=0.73\end{array}$ & $\begin{array}{l}31.54 / 27.95 \\
361.50, \mathrm{p}=0.37\end{array}$ & $\begin{array}{l}30.50 / 27.91 \\
360.00, p=0.49\end{array}$ \\
\hline $\begin{array}{l}\text { Resources are being identified to support the systemic, } \\
\text { programmatic changes implemented through the work of } \\
\text { the coalition }\end{array}$ & $\begin{array}{l}25.56 / 26.46 \\
313.50, \mathrm{p}=0.80\end{array}$ & $\begin{array}{l}35.62 / 33.62 \\
536.50, \mathrm{p}=0.60\end{array}$ & $\begin{array}{l}31.30 / 32.46 \\
457.50, \mathrm{p}=0.75\end{array}$ \\
\hline $\begin{array}{l}\text { The coalition is essential to the improvement of pediatric } \\
\text { obesity }\end{array}$ & $\begin{array}{l}41.89 / 44.51 \\
827.50, p=0.58\end{array}$ & $\begin{array}{l}55.70 / 58.28 \\
1523.00, \mathrm{p}=0.60\end{array}$ & $\begin{array}{l}46.57 / 47.27 \\
1010.50, p=0.88\end{array}$ \\
\hline $\begin{array}{l}\text { One or a small number of people or agencies could make } \\
\text { significant progress in pediatric obesity without the } \\
\text { coalition }\end{array}$ & $\begin{array}{l}33.69 / 39.34 \\
512.00, \mathrm{p}=0.23\end{array}$ & $\begin{array}{l}52.01 / 50.05 \\
1224.50, \mathrm{p}=0.72\end{array}$ & $\begin{array}{l}46.47 / 37.95 \\
595.50, \mathrm{p}=0.10\end{array}$ \\
\hline In general I am satisfied with the coalition & $\begin{array}{l}42.84 / 46.59 \\
874.00, p=0.43\end{array}$ & $\begin{array}{l}56.29 / 67.95 \\
1554.00, \mathrm{p}=0.03\end{array}$ & $\begin{array}{l}51.56 / 53.85 \\
1231.00, \mathrm{p}=0.67\end{array}$ \\
\hline
\end{tabular}

Significant measures, $\mathrm{p}<0.05$, are shaded gray

\section{Coalition Synergy}

\section{Mission strategies and action plans}

In the control group, a greater percentage of members agreed that their respective action plan became more clearly defined from baseline to follow-up. However, control group coalition member responses indicated that overall coalition organization and preparedness decreased 
between baseline and follow-up. This change was indicated by a decline in the number of members who agreed that "notification of meetings is timely" and "background materials needed for meetings are prepared and distributed in advance of meetings (agendas, minutes, study documents)." In contrast, the members of the intervention coalition responded that coalition organization and preparedness was enhanced between baseline and follow-up, based on the same measure. When comparing the two experimental groups, the intervention coalitions' level of agreement was significantly higher statistically. In addition, members of the intervention group listed strategic planning and advocacy for public policy objectives as a function of their coalitions more often than members of the control group.

Table 3.14 Mann-Whitney $U$ rank tests for mission strategy and action plan variables

\begin{tabular}{|c|c|c|c|}
\hline Mission strategy/Action plan Measure & Control & Intervention & Control vs. Intervention \\
\hline \multicolumn{4}{|l|}{$\begin{array}{l}\text { Indicate whether the following functions are major, } \\
\text { minor, or not a function in your coalition... }\end{array}$} \\
\hline Network with other professionals & $\begin{array}{l}41.38 / 41.65 \\
827.00, \mathrm{p}=0.945\end{array}$ & $\begin{array}{l}66.02 / 67.94 \\
2146.00, p=0.69\end{array}$ & $\begin{array}{l}52.23 / 53.42 \\
1229.50, p=0.79\end{array}$ \\
\hline Network with concerned citizens & $\begin{array}{l}42.59 / 40.18 \\
783.50, p=0.58\end{array}$ & $\begin{array}{l}67.53 / 59.34 \\
1726.00, p=0.15\end{array}$ & $\begin{array}{l}53.19 / 48.10 \\
1029.00, p=0.34\end{array}$ \\
\hline Conduct strategic planning & $\begin{array}{l}41.50 / 39.28 \\
748.00, p=0.63\end{array}$ & $\begin{array}{l}65.80 / 64.16 \\
2026.00, p=0.73\end{array}$ & $\begin{array}{l}42.47 / 54.30 \\
863.00, p=0.02\end{array}$ \\
\hline Make decisions about priority needs and problems & $\begin{array}{l}43.33 / 43.71 \\
904.00, p=0.91\end{array}$ & $\begin{array}{l}64.91 / 69.06 \\
2073.00, p=0.21\end{array}$ & $\begin{array}{l}49.71 / 54.87 \\
1148.00, p=0.10\end{array}$ \\
\hline Recommend or make decisions to allocate resources & $\begin{array}{l}38.77 / 42.41 \\
725.50, \mathrm{p}=0.39\end{array}$ & $\begin{array}{l}65.39 / 60.73 \\
1806.50, p=0.39\end{array}$ & $\begin{array}{l}54.99 / 49.43 \\
1083.50, \mathrm{p}=0.27\end{array}$ \\
\hline Operate particular programs or activities & $\begin{array}{l}44.30 / 43.66 \\
929.00, p=0.88\end{array}$ & $\begin{array}{l}63.19 / 64.75 \\
1963.50, p=0.79\end{array}$ & $\begin{array}{l}59.05 / 50.86 \\
1146.00, p=0.13\end{array}$ \\
\hline Advocate for local public policy objectives & $\begin{array}{l}41.45 / 36.35 \\
642.00, p=0.27\end{array}$ & $\begin{array}{l}61.76 / 61.23 \\
1844.00, p=0.93\end{array}$ & $\begin{array}{l}44.41 / 51.83 \\
940.00, p=0.16\end{array}$ \\
\hline Advocate for state public policy objectives & $\begin{array}{l}40.10 / 34.60 \\
581.00, p=0.23\end{array}$ & $\begin{array}{l}58.55 / 55.36 \\
1505.00, p=0.58\end{array}$ & $\begin{array}{l}38.59 / 49.90 \\
720.50, p=0.03\end{array}$ \\
\hline Provide funding for current programs & $\begin{array}{l}39.06 / 42.18 \\
733.50, p=0.51\end{array}$ & $\begin{array}{l}58.17 / 60.78 \\
1663.00, p=0.66\end{array}$ & $\begin{array}{l}51.74 / 47.31 \\
1008.50, p=0.42\end{array}$ \\
\hline Raise funds to sustain long-term coalition activities & $\begin{array}{l}40.12 / 36.50 \\
646.00, p=0.45\end{array}$ & $\begin{array}{l}51.37 / 54.54 \\
1294.00, \mathrm{p}=0.56\end{array}$ & $\begin{array}{l}38.91 / 48.02 \\
728.00, \mathrm{p}=0.08\end{array}$ \\
\hline
\end{tabular}

Significant measures, $\mathrm{p}<0.05$, are shaded gray 
Table 3.15 Mann-Whitney $U$ rank tests for mission strategy and action plan variables

\begin{tabular}{|c|c|c|c|}
\hline Mission strategy/Action plan Measure & Control & Intervention & Control vs. Intervention \\
\hline $\begin{array}{l}\text { Rank your level of agreement... } \\
\text { Our coalition has a clear and shared understanding of the } \\
\text { problems we are trying to address }\end{array}$ & $\begin{array}{l}40.03 / 45.49 \\
733.50, p=0.51\end{array}$ & $\begin{array}{l}65.09 / 68.77 \\
2086.00, p=0.53\end{array}$ & $\begin{array}{l}52.92 / 54.59 \\
1270.00, p=0.76\end{array}$ \\
\hline $\begin{array}{l}\text { There is a general agreement with respect to the mission } \\
\text { of the coalition }\end{array}$ & $\begin{array}{l}41.39 / 46.04 \\
760.50, p=0.25\end{array}$ & $\begin{array}{l}62.45 / 67.22 \\
1917.00, \mathrm{p}=0.41\end{array}$ & $\begin{array}{l}50.88 / 56.54 \\
1204.50, p=0.29\end{array}$ \\
\hline $\begin{array}{l}\text { There is general agreement with respect to the priorities } \\
\text { of the coalition }\end{array}$ & $\begin{array}{l}42.17 / 46.26 \\
817.50, p=0.32\end{array}$ & $\begin{array}{l}63.85 / 64.13 \\
1997.00, p=0.96\end{array}$ & $\begin{array}{l}56.74 / 52.43 \\
1219.00, \mathrm{p}=0.43\end{array}$ \\
\hline $\begin{array}{l}\text { Members agree on the strategies the coalition should use } \\
\text { in pursuing its priorities }\end{array}$ & $\begin{array}{l}39.64 / 42.54 \\
848.00, p=0.39\end{array}$ & $\begin{array}{l}54.63 / 63.61 \\
1465.00, p=0.09\end{array}$ & $\begin{array}{l}52.92 / 50.66 \\
1162.00, \mathrm{p}=0.66\end{array}$ \\
\hline $\begin{array}{l}\text { Our action plan defines well the roles, responsibilities } \\
\text { and timelines for conducting the activities that work } \\
\text { towards achieving the stated mission of the coalition }\end{array}$ & $\begin{array}{l}31.64 / 40.49 \\
758.50, \mathrm{p}=0.52\end{array}$ & $\begin{array}{l}51.14 / 56.24 \\
1275.50, \mathrm{p}=0.35\end{array}$ & $\begin{array}{l}51.67 / 45.86 \\
921.50, \mathrm{p}=0.27\end{array}$ \\
\hline Notification of meetings is timely & $\begin{array}{l}51.60 / 40.43 \\
473.00, \mathrm{p}=0.047\end{array}$ & $\begin{array}{l}63.54 / 75.29 \\
1975.00, p=0.05\end{array}$ & $\begin{array}{l}50.81 / 59.91 \\
1231.00, \mathrm{p}=0.10\end{array}$ \\
\hline $\begin{array}{l}\text { Background materials needed for meetings are prepared } \\
\& \text { distributed in advance of meetings (agendas, minutes, } \\
\text { study documents) }\end{array}$ & $\begin{array}{l}51.73 / 37.12 \\
795.00, \mathrm{p}=0.02\end{array}$ & $\begin{array}{l}58.82 / 73.51 \\
1689.50, \mathrm{p}=0.01\end{array}$ & $\begin{array}{l}44.78 / 69.75 \\
1021.00, p=0.003\end{array}$ \\
\hline $\begin{array}{l}\text { Informative committee and/or task force reports are } \\
\text { routinely made to the entire coalition }\end{array}$ & $\begin{array}{l}43.49 / 37.89 \\
661.00, p=0.003\end{array}$ & $\begin{array}{l}57.44 / 66.81 \\
1621.00, p=0.10\end{array}$ & $\begin{array}{l}46.86 / 54.76 \\
1281.00, p=0.15\end{array}$ \\
\hline
\end{tabular}

Significant measures, $\mathrm{p}<0.05$, are shaded gray

\section{Participation}

In the intervention group, satisfaction with coalition operations increased at follow-up. Benefits of organizational participation in coalition activities increased from baseline (56.6\%) to followup (77.5\%). Significantly more intervention group coalition members reported working on sponsored activity implementation. However, organizational support was perceived to be stronger in the control group, as indicated by coalition members' level of agreement with the statements "staff from my organization contribute time to the coalition," "my organization supports the positions of the coalition publicly," and "overall, my organization is committed to the work of the coalition." Moreover, coalition members in the intervention group reported fewer benefits for their organization from the coalition.

Coalition members from both groups indicated that problems related to their participation in the coalition decreased. In the control group, participation issues improved on all measures 
from baseline to follow-up, while intervention coalitions improved on some measures. In general, coalitions in the control group had more issues with participation at baseline, but these leveled out with intervention group responses at follow-up.

Table 3.16 Mann-Whitney $U$ rank tests for tests of coalition participation benefits

\begin{tabular}{|c|c|c|c|}
\hline Benefits of participation & Control & Intervention & Control vs. Intervention \\
\hline \multicolumn{4}{|l|}{$\begin{array}{l}\text { Rank the extent to which the following been a } \\
\text { benefit to your participation on the coalition... }\end{array}$} \\
\hline $\begin{array}{l}\text { Developing collaborative relationships with } \\
\text { other agencies }\end{array}$ & $\begin{array}{c}44.99 / 41.71 \\
846.50, p=0.46\end{array}$ & $\begin{array}{c}71.93 / 63.07 \\
1947.50, p=0.14\end{array}$ & $\begin{array}{c}59.71 / 49.89 \\
1064.50, p=0.08\end{array}$ \\
\hline $\begin{array}{l}\text { Helping my organization move toward our } \\
\text { goals }\end{array}$ & $\begin{array}{c}45.46 / 41.14 \\
824.50, p=0.37\end{array}$ & $\begin{array}{c}69.08 / 61.80 \\
1875.50, p=0.23\end{array}$ & $\begin{array}{c}60.06 / 47.09 \\
933.50, p=0.02\end{array}$ \\
\hline $\begin{array}{l}\text { Getting access to target populations with } \\
\text { whom we have previously had little contact }\end{array}$ & $\begin{array}{c}44.32 / 38.24 \\
712.00, \mathrm{p}=0.21\end{array}$ & $\begin{array}{c}67.82 / 59.31 \\
1716.00, \mathrm{p}=0.17\end{array}$ & $\begin{array}{c}56.58 / 48.48 \\
1023.00, p=0.16\end{array}$ \\
\hline Getting funding for my organization & $\begin{array}{c}38.78 / 32.20 \\
501.00, \mathrm{p}=0.16\end{array}$ & $\begin{array}{c}55.79 / 58.15 \\
1528.50, \mathrm{p}=0.67\end{array}$ & $\begin{array}{c}45.20 / 44.14 \\
849.00, p=0.84\end{array}$ \\
\hline Getting services for our clients & $\begin{array}{c}41.88 / 35.54 \\
614.00, p=0.19\end{array}$ & $\begin{array}{c}61.65 / 60.38 \\
1790.50, p=0.84\end{array}$ & $\begin{array}{c}51.80 / 47.42 \\
987.00, \mathrm{p}=0.45\end{array}$ \\
\hline Getting client referrals from others & $\begin{array}{c}38.68 / 33.78 \\
553.00, \mathrm{p}=0.30\end{array}$ & $\begin{array}{c}53.53 / 56.39 \\
1406.00, \mathrm{p}=0.62\end{array}$ & $\begin{array}{c}46.63 / 43.29 \\
828.00, p=0.54\end{array}$ \\
\hline $\begin{array}{l}\text { Increasing my professional skills and } \\
\text { knowledge }\end{array}$ & $\begin{array}{c}43.79 / 44.26 \\
926.00, p=0.93\end{array}$ & $\begin{array}{c}68.64 / 66.39 \\
2168.50, p=0.72\end{array}$ & $\begin{array}{c}56.10 / 52.79 \\
1244.00, \mathrm{p}=0.57\end{array}$ \\
\hline $\begin{array}{l}\text { Staying well informed in a rapidly changing } \\
\text { environment }\end{array}$ & $\begin{array}{c}45.67 / 42.04 \\
861.50, p=0.46\end{array}$ & $\begin{array}{c}65.50 / 67.44 \\
2112.00, p=0.75\end{array}$ & $\begin{array}{c}52.40 / 55.74 \\
1276.00, \mathrm{p}=0.56\end{array}$ \\
\hline Getting access to key policy makers & $\begin{array}{c}36.10 / 37.00 \\
624.00, p=0.85\end{array}$ & $\begin{array}{c}62.66 / 60.1906 .5034 \\
1790.00, p=0.71\end{array}$ & $\begin{array}{c}46.80 / 47.11 \\
969.50, p=0.96\end{array}$ \\
\hline $\begin{array}{l}\text { Increasing my sense that others share my } \\
\text { goals and concerns }\end{array}$ & $\begin{array}{c}47.64 / 39.73 \\
769.00, p=0.11\end{array}$ & $\begin{array}{c}67.01 / 66.99 \\
2209.50, p=0.10\end{array}$ & $\begin{array}{c}50.86 / 56.64 \\
1214.50, \mathrm{p}=0.31\end{array}$ \\
\hline $\begin{array}{l}\text { Getting support for policy issues our } \\
\text { organization feels strongly about }\end{array}$ & $\begin{array}{c}40.02 / 35.56 \\
614.00, \mathrm{p}=0.35 \\
\end{array}$ & $\begin{array}{c}66.80 / 58.33 \\
1659.00, p=0.17\end{array}$ & $\begin{array}{c}47.35 / 49.89 \\
1015.00, \mathrm{p}=0.66\end{array}$ \\
\hline
\end{tabular}

Significant measures, $\mathrm{p}<0.05$, are shaded gray 
Table 3.17 Mann-Whitney $U$ rank of variables testing coalition member perception of barriers to participation

\begin{tabular}{|c|c|c|c|}
\hline Problems for participation & Control & Intervention & $\begin{array}{l}\text { Control vs. } \\
\text { Intervention }\end{array}$ \\
\hline \multicolumn{4}{|l|}{$\begin{array}{l}\text { Rank the extent to which the following been a } \\
\text { barrier to your participation on the coalition... }\end{array}$} \\
\hline $\begin{array}{l}\text { Coalition activities do not reach my primary } \\
\text { constituency }\end{array}$ & $\begin{array}{c}30.40 / 47.99 \\
385.5, \mathrm{p}=0.00\end{array}$ & $\begin{array}{c}57.04 / 60.80 \\
1598.0, p=0.48\end{array}$ & $\begin{array}{c}52.23 / 46.36 \\
937.0, p=0.21\end{array}$ \\
\hline $\begin{array}{l}\text { My organization doesn't get enough public } \\
\text { recognition for our work in the coalition }\end{array}$ & $\begin{array}{c}32.94 / 49.28 \\
470.5, p=0.00\end{array}$ & $\begin{array}{c}52.55 / 58.93 \\
1354.0, \mathrm{p}=0.15\end{array}$ & $\begin{array}{c}46.68 / 50.43 \\
1024.0, p=0.36\end{array}$ \\
\hline Being involved in policy and advocacy & $\begin{array}{c}29.77 / 41.80 \\
381.0, p=0.01\end{array}$ & $\begin{array}{c}44.60 / 54.69 \\
970.5, p=0.03\end{array}$ & $\begin{array}{c}40.42 / 42.90 \\
1212.5, p=0.55\end{array}$ \\
\hline My skills and time are not well-used & $\begin{array}{c}31.16 / 51.92 \\
381.0, \mathrm{p}=0.00\end{array}$ & $\begin{array}{c}59.47 / 63.40 \\
1738.5, p=0.39\end{array}$ & $\begin{array}{c}51.00 / 49.43 \\
3114.0, p=0.70\end{array}$ \\
\hline $\begin{array}{l}\text { My (or my organization's) opinion is not } \\
\text { valued }\end{array}$ & $\begin{array}{c}31.14 / 53.50 \\
380.0, \mathrm{p}=0.00\end{array}$ & $\begin{array}{c}59.71 / 68.86 \\
1751.5, p=0.02\end{array}$ & $\begin{array}{c}55.00 / 51.87 \\
3475.0, p=0.13\end{array}$ \\
\hline $\begin{array}{l}\text { The coalition is not taking any meaningful } \\
\text { action }\end{array}$ & $\begin{array}{c}35.88 / 46.79 \\
597.0, \mathrm{p}=0.01\end{array}$ & $\begin{array}{c}58.57 / 66.84 \\
1686.0, p=0.06\end{array}$ & $\begin{array}{c}49.53 / 54.97 \\
1882.0, p=0.16\end{array}$ \\
\hline $\begin{array}{l}\text { I am often the only voice representing my } \\
\text { viewpoint }\end{array}$ & $\begin{array}{c}31.55 / 51.18 \\
422.0, p=0.00\end{array}$ & $\begin{array}{c}59.12 / 63.81 \\
1717.0, p=0.21\end{array}$ & $\begin{array}{c}50.79 / 51.13 \\
1981.0, p=0.91\end{array}$ \\
\hline $\begin{array}{l}\text { The financial burden of traveling to coalition } \\
\text { meetings is too high }\end{array}$ & $\begin{array}{c}32.61 / 54.69 \\
432.5, \mathrm{p}=0.00\end{array}$ & $\begin{array}{c}61.90 / 69.10 \\
1878.5, p=0.05\end{array}$ & $\begin{array}{c}54.20 / 52.26 \\
3397.0, p=0.39\end{array}$ \\
\hline $\begin{array}{l}\text { The financial burden of participating in } \\
\text { coalition activities (barring travel) is too } \\
\text { high }\end{array}$ & $\begin{array}{c}31.82 / 54.26 \\
409.5, \mathrm{p}=0.00\end{array}$ & $\begin{array}{c}60.51 / 68.49 \\
1792.5, p=0.03\end{array}$ & $\begin{array}{c}54.76 / 51.09 \\
3269.5, p=0.07\end{array}$ \\
\hline $\begin{array}{l}\text { The coalition is competing with my } \\
\text { organization }\end{array}$ & $\begin{array}{c}31.87 / 54.00 \\
399.0, \mathrm{p}=0.00\end{array}$ & $\begin{array}{c}61.04 / 69.69 \\
1829.5, p=0.01\end{array}$ & $\begin{array}{c}54.00 / 52.43 \\
3513.0, p=0.29\end{array}$ \\
\hline
\end{tabular}

Significant measures, $\mathrm{p}<0.05$, are shaded gray

Table 3.18 Mann-Whitney $U$ rank of variables testing the costs and benefits of member participation

\begin{tabular}{|l|l|l|l|}
\hline Cost/Benefit & Control & Intervention & $\begin{array}{c}\text { Control vs. } \\
\text { Intervention }\end{array}$ \\
\hline $\begin{array}{l}\text { From your organization's perspective (if applicable), do the } \\
\text { benefits of participation in the coalition appear to outweigh the } \\
\text { costs at this point? }\end{array}$ & $3.90, \mathrm{p}=0.27$ & $9.09, \mathrm{p}=0.03$ & $6.58, \mathrm{p}=0.09$ \\
\hline $\begin{array}{l}\text { From your own professional and/or personal perspective, do } \\
\text { the benefits of participation in the coalition appear to outweigh } \\
\text { the costs at this point? }\end{array}$ & $4.42, \mathrm{p}=0.22$ & $4.41, \mathrm{p}=0.22$ & $4.11, \mathrm{p}=0.25$ \\
\hline
\end{tabular}

Significant measures, $\mathrm{p}<0.05$, are shaded gray 
Table 3.19 Mann-Whitney U rank tests of participation variables

\begin{tabular}{|c|c|c|c|}
\hline Participation Measure & Control & Intervention & $\begin{array}{l}\text { Control vs. } \\
\text { Intervention }\end{array}$ \\
\hline $\begin{array}{l}\text { Over the past year, rank how involved you have been in } \\
\text { coalition activities: not at all, a little, fairly, or very. }\end{array}$ & $\begin{array}{l}44.04 / 42.75 \\
873.00, \mathrm{p}=0.81\end{array}$ & $\begin{array}{l}55.89 / 67.11 \\
1518.00, \mathrm{p}=0.07\end{array}$ & $\begin{array}{l}47.33 / 49.98 \\
1038.00, \mathrm{p}=0.64\end{array}$ \\
\hline \multicolumn{4}{|l|}{$\begin{array}{l}\text { Over the past year, rank how many times you personally } \\
\text { have done any of the following (never, rarely, sometimes, } \\
\text { often): }\end{array}$} \\
\hline Recruited new members & $\begin{array}{l}43.53 / 39.14 \\
746.50, p=0.37\end{array}$ & $\begin{array}{l}67.23 / 65.82 \\
2129.50, p=0.82\end{array}$ & $\begin{array}{l}53.21 / 53.66 \\
1281.00, \mathrm{p}=0.94\end{array}$ \\
\hline Served as a spokesperson & $\begin{array}{l}42.53 / 43.55 \\
875.50, \mathrm{p}=0.84\end{array}$ & $\begin{array}{l}69.45 / 61.78 \\
1861.50, p=0.22\end{array}$ & $\begin{array}{l}60.40 / 49.49 \\
1037.50, p=0.06\end{array}$ \\
\hline $\begin{array}{l}\text { Attempted to get outside support for coalition positions on } \\
\text { key issues }\end{array}$ & $\begin{array}{l}39.63 / 41.57 \\
753.50, p=0.70\end{array}$ & $\begin{array}{l}69.30 / 61.70 \\
1865.50, p=0.22\end{array}$ & $\begin{array}{l}56.56 / 47.92 \\
970.00, p=0.13\end{array}$ \\
\hline $\begin{array}{l}\text { Worked on implementing activities or events sponsored by } \\
\text { the coalition }\end{array}$ & $\begin{array}{l}41.29 / 46.04 \\
818.50, p=0.36\end{array}$ & $\begin{array}{l}67.14 / 65.88 \\
2136.00, p=0.85\end{array}$ & $\begin{array}{l}65.63 / 47.06 \\
875.00, p=0.002\end{array}$ \\
\hline Acquired funding or other resources for the coalition & $\begin{array}{l}40.48 / 42.68 \\
791.00, \mathrm{p}=0.65\end{array}$ & $\begin{array}{l}63.35 / 63.65 \\
1974.50, \mathrm{p}=0.96\end{array}$ & $\begin{array}{l}54.43 / 48.09 \\
1028.50, \mathrm{p}=0.23\end{array}$ \\
\hline \multicolumn{4}{|l|}{$\begin{array}{l}\text { Rank your level of agreement with the following statements } \\
\text { (from an organizational perspective): }\end{array}$} \\
\hline I feel that I have a voice in what the coalition decides & $\begin{array}{l}43.06 / 46.23 \\
891.00, p=0.51\end{array}$ & $\begin{array}{l}65.73 / 67.23 \\
2126.50, p=0.78\end{array}$ & $\begin{array}{l}59.99 / 51.27 \\
1140.50, \mathrm{p}=0.10\end{array}$ \\
\hline I go to coalition meetings only because it is part of my job & $\begin{array}{l}43.53 / 47.85 \\
908.00, p=0.40\end{array}$ & $\begin{array}{l}66.29 / 66.70 \\
2162.50, p=0.95\end{array}$ & $\begin{array}{l}61.80 / 50.90 \\
1115.00, p=0.06\end{array}$ \\
\hline I am satisfied with how the coalition operates & $\begin{array}{l}43.94 / 41.84 \\
849.00, p=0.68\end{array}$ & $\begin{array}{l}51.67 / 70.41 \\
1286.00, p=0.00\end{array}$ & $\begin{array}{l}49.29 / 52.81 \\
1132.00, \mathrm{p}=0.51\end{array}$ \\
\hline I feel a strong sense of "loyalty" to the coalition & $\begin{array}{l}41.69 / 42.37 \\
841.00, \mathrm{p}=0.89\end{array}$ & $\begin{array}{l}62.55 / 62.46 \\
1906.50, p=0.99\end{array}$ & $\begin{array}{l}56.08 / 51.25 \\
1156.00, \mathrm{p}=0.38\end{array}$ \\
\hline Staff from my organization contribute time to the coalition & $\begin{array}{l}41.57 / 39.32 \\
753.00, \mathrm{p}=0.63\end{array}$ & $\begin{array}{l}63.16 / 54.00 \\
1416.00, p=0.11\end{array}$ & $\begin{array}{l}58.20 / 43.08 \\
771.50, p=0.01\end{array}$ \\
\hline $\begin{array}{l}\text { Volunteers from my organization contribute time to the } \\
\text { coalition }\end{array}$ & $\begin{array}{l}30.03 / 31.00 \\
435.00, \mathrm{p}=0.82\end{array}$ & $\begin{array}{l}50.17 / 50.81 \\
1232.00, \mathrm{p}=0.91\end{array}$ & $\begin{array}{l}43.98 / 39.34 \\
667.50, p=0.37\end{array}$ \\
\hline $\begin{array}{l}\text { My organization supports the positions of the coalition } \\
\text { publicly }\end{array}$ & $\begin{array}{l}37.44 / 43.21 \\
657.50, p=0.21\end{array}$ & $\begin{array}{l}61.23 / 55.95 \\
1527.00, \mathrm{p}=0.31\end{array}$ & $\begin{array}{l}56.74 / 42.90 \\
744.00, \mathrm{p}=0.01\end{array}$ \\
\hline $\begin{array}{l}\text { Overall, my organization is committed to the work of the } \\
\text { coalition }\end{array}$ & $\begin{array}{l}40.64 / 44.75 \\
788.50, p=0.38\end{array}$ & $\begin{array}{l}62.62 / 57.59 \\
1617.50, p=0.34\end{array}$ & $\begin{array}{l}56.68 / 46.71 \\
943.00, p=0.05\end{array}$ \\
\hline My organization contributes funds to support the coalition & $\begin{array}{l}32.12 / 32.93 \\
497.00, \mathrm{p}=0.85\end{array}$ & $\begin{array}{l}50.45 / 50.55 \\
1243.00, \mathrm{p}=0.99\end{array}$ & $\begin{array}{l}48.30 / 38.43 \\
606.00, \mathrm{p}=0.06\end{array}$ \\
\hline
\end{tabular}

Significant measures, $\mathrm{p}<0.05$, are shaded gray 


\section{Chapter 4 - Discussion}

To date, research on coalition function has focused on many of the same constructs evaluated in this study: recruitment and membership, decision-making, conflict, leadership, staffing, trust, communication, action plan, and participation. ${ }^{11,12,14,24,37-40,50-62}$ Clearly, these factors have been recognized as key processes to ensuring success along the roadmap of coalition development. ${ }^{62}$ While coalitions are frequently employed as research partners in CEnR, ${ }^{7-9}$ there is little research that evaluates the effects of this partnership on the coalitions. ${ }^{7,8,14,84}$ Guided by the CCAT model, the purpose of this study was to evaluate the effects of researcher-coalition collaboration in the pilot year of a four-year intervention program targeting childhood obesity in rural, low-income communities. The null hypotheses were that coalition constructs from both experimental groups would (a) remain steady after the first year of partnership, and (b) be comparable to each other.

\section{Coalition Membership}

Coalition membership occurs early in the formation stage of the CCAT. ${ }^{10,62}$ Although the coalitions examined in this study were already established in their respective communities, some measures of membership were examined as an intermediate output. Coalitions are continuously evolving throughout the stages, ${ }^{79}$ especially in response to an external stimulus like CEnR partnership. The data supported a relationship between greater researcher collaboration and enhanced organizational representation and recruitment activity over the year. One interpretation of these findings is that coalitions with more activity in the partnership simply become more active in general. However, it is notable that no progress in member resources or skills was observed. Thus, the results may indicate that the perceived ability of coalition members to take action remained steady, even with an increase in pooled resources. If that is true, it could 
counteract the benefits of organizational presence and progress along the CCAT could stall. Alternatively (and in accordance with the CCAT model), greater organizational support may advance the coalition regardless of member perceptions, simply by including more stakeholders and augmenting the reach of its activities.

\section{Coalition Systems: Structures, Operation and Processes, Leadership and Staffing}

The maintenance constructs of the CCAT, which include mechanisms and characteristics of coalition function, make synergy more likely. ${ }^{5,80}$ Relationships between key coalition maintenance factors and CEnR were observed in most categories. In particular, decision-making, conflict, leadership, and staffing were all positively related to CEnR (demonstrated by significant changes in both experimental groups), but in many of the categories only a small number of measures showed statistically significant change. These findings suggest that any degree of academic partner involvement may promote community change by improving the operational processes of coalition function. However, this influence may only be slight. It should be noted that the amount of time between baseline and follow-up (one year) may have been too short to properly capture any progress in coalition functioning and that these findings may simply be transitional indicators.

Changes in measures that addressed coalition leadership were almost exclusively observed in the intervention group. Similarly, variables that assessed coalition capacity, trust and communication were unique to the intervention group, suggesting that a more involved partnership (specifically through a community coach) may drive these measures. Quality of

communication has been linked to member satisfaction, ${ }^{51}$ and these observations support those findings. Furthermore, the perceived evolution of coalition leadership and capacity is not 
surprising, as community coaches were trained specifically to address these variables. It is possible that even in the most highly involved CEnR partnerships, the progress of such measures may not be statistically significant without the presence of a trained community coach.

\section{Synergy: Member Engagement, Assessment and Planning}

In the control group, all ten variables that evaluated barriers to member participation were notably decreased at follow-up, indicating that the introduction of a CEnR partnership alleviated some of the burden associated with engagement in the coalition. Similar (though less pronounced) findings were also observed in the intervention group. An explanation may be that the coalitions had funds available to them, which enhanced member sense of purpose and/or the ability to address coalition goals regardless of guidance, or coaching, within the coalition. In the control group, member responses indicate that coalition organization and preparedness decreased from baseline to follow-up. This is significant since it may indicate that although the control coalitions were provided funding, purposely limited guidance regarding the use of these funds may adversely impact the coalition's function. One possible explanation could be that in spite of adequate funding, control coalitions were not prepared to move forward with project implementation. Comparison of the study groups at follow-up demonstrated a positive effect on coalition action plan variables (including planning and advocacy) in the intervention group.

Developing a high quality action plan has been described as a professional skill, ${ }^{51}$ and may have been directly impacted by training of the community coaches at academic institutions.

\section{Experimental Considerations}

While past studies have examined changes in community coalitions, this is the first known study that examines the dose-response relationship of community health coalitions within the CEnR framework. Additionally, the current study is rooted in coalition theory, which enables 
us to make inferences regarding intermediate outcomes. ${ }^{15,78}$ It is noteworthy that numerous models of collaborative approaches were examined in this study, and these findings may guide future research on the types of relationships that can best foster community health promotion. ${ }^{59}$

This study contains several limitations. First, the study was quasi-experimental, so causality must be approached with caution. Also, while our one-year study design was unique, it may not accurately predict the impact of CEnR over longer periods of time. Next, the study procedure for data collection varied somewhat from state to state, and even from baseline to follow-up in some states. Additionally, in some states only members that attended the coalition meeting participated in the CSAS. In other states, only members that were motivated to complete the CSAS on their own time and mail it back completed it. Because these collection methods promoted response by active coalition members, it may have positively biased the findings (as less active members may be less inclined to provide positive feedback). Also, our evaluation tool was not designed for research purposes, but rather to better educate coalitions on their own functioning. However, there is no "gold standard" for measuring coalition constructs, nor is there an existing tool that is widely employed to assess coalition function. ${ }^{85}$ Furthermore, tools that have high validity or reliability in one population may not perform as well when applied to other populations. $^{60}$ This reality makes it difficult to identify and apply findings across 24 distinct populations.

This study also did not compare experimental groups at baseline, therefore, baseline differences between control and intervention were only assumed, not observed. Lastly, community coalitions are inherently fluid and subject to uncontrollable environmental influences that may impact study findings. ${ }^{80}$ Although the coalitions in this study were initially selected to be comparable, each coalition seemed to cycle through various stages of the CCAT differently. 
However, since the results were aggregated, the collective scores from the CSAS should reflect conditions of the group as a whole.

Findings from this study should be informative to the growing number of researchers seeking to collaborate with community health coalitions. We found engagement of community health coalitions over one-year was related to the improvement of multiple measures of coalition function including decision-making, conflict resolution, coalition capacity, action plan formation and participation. Measures of coalition leadership, staffing, and trust were predominately related to coalition engagement beyond funding. Coalition membership and communication were variables that responded solely to the stronger "dose" CEnR partnership, involving the insertion of an academically-trained community coach, were coalition membership and communication. Overall, we observed more progress in measures of coalition functioning along the CCAT in those coalitions that were more involved with academic partners. These results should be interpreted and applied with caution as some negative effects of CEnR were observed in the lighter "dose" partnerships (including some measures of coalition readiness and action plan formation), which may have been due to the sudden influx of funding.

Additional research is required to further examine the dose-response relationship between academic and community partners to determine the appropriate level of engagement, and the effect of various levels of funding on coalitions. Although CBPR is viewed as the pinnacle of CEnR approaches (against which all other modalities are judged), this method may not always be feasible - particularly in geographically and socially isolated populations. Future research should focus on varying degrees and type of collaboration between academic and community partners. 


\section{References}

1. Centers for Disease Control and Prevention. Social Determinants of Health Web site. http://www.cdc.gov/socialdeterminants/Definitions.html. Published March 21 2014. Updated 2014. Accessed March 01, 2015.

2. Eberhardt MS, Pamuk ER. The importance of place of residence: Examining health in rural and nonrural areas. Am J Public Health. 2004;94(10):1682-1686.

3. Hartley D. Rural health disparities, population health, and rural culture. Am J Public Health. 2004;94(10):1675-1678.

4. Downey LH. Rural populations and health: Determinants, disparities, and solutions. Prev Chronic Dis. 2013;10(130097).

5. U.S. Department of Health and Human Services. Rural behavioral health programs and promising practices. Rural Behavioral Manual. 2011.

6. U.S. Department of Health and Human Services. Healthy people 2020: Disparities. 2015.

7. Downey LM, Ireson CL, Slavova S, McKee G. Defining elements of success: A critical pathway of coalition development. Health Promot Pract. 2008;9(2):130-139.

8. Israel BA, Schulz AJ, Parker EA, Becker AB, Community-Campus Partnerships for Health. Community-based participatory research: Policy recommendations for promoting a partnership approach in health research. Educ Health (Abingdon). 2001;14(2):182-197.

9. Roussos ST, Fawcett SB. A review of collaborative partnerships as a strategy for improving community health. Annu Rev Public Health. 2000;21:369-402.

10. Florin P, Mitchell R, Stevenson J. Identifying training and technical assistance needs in community coalitions: A developmental approach. Health Educ Res. 1993;8(3):417-432.

11. Clark NM, Lachance L, Doctor LJ, et al. Policy and system change and community coalitions: Outcomes from allies against asthma. Health Educ Behav. 2014;41(5):528-538.

12. Sandoval JA, Lucero J, Oetzel J, et al. Process and outcome constructs for evaluating community-based participatory research projects: A matrix of existing measures. Health Education Research. 2012;27(4):680-690.

13. Clark NM, Malveaux F, Friedman AR. An introduction to allies against asthma and this special issue. Health Promot Pract. 2006;7(2 Suppl):8S-12S.

14. Isler MR, Corbie-Smith G. Practical steps to community engaged research: From inputs to outcomes. J Law Med Ethics. 2012;40(4):904-914. 
15. Sánchez V, Sanders M, Andrews ML, Hale R, Carrillo C. Community health coalitions in context: Associations between geographic context, member type and length of membership with coalition functions. Health Education Research. 2014;29(5):715-729.

16. United States Department of Agriculture. Rural economy \& population. USDA Economic Research Service Web site. http://www.ers.usda.gov/topics/rural-economypopulation/population-migration.aspx. Published April 3 2014. Updated 2014. Accessed March $1,2015$.

17. National Association of Community Health Centers Inc. Removing barriers to care: Community health centers in rural areas fact sheet. 2013;1013.

18. U.S. Department of Health and Human Services. Healthy people 2020: Access to health services. Healthy People 2020 Topics \& Objectives Web site. https://www.healthypeople.gov/2020/topics-objectives/topic/Access-to-Health-Services. Published 2014. Updated 2015. Accessed March 1, 2015.

19. Flores G. Language barriers to health care in the united states. $N$ Engl J Med. 2006;355(3):229-231.

20. Hill J, You W, Zoellner J. Disparities in obesity among rural and urban residents in a health disparate region. BMC Public Health. 2014;14(1):1051.

21. Lutfiyya MN, Chang LF, Lipsky MS. A cross-sectional study of US rural adults' consumption of fruits and vegetables: Do they consume at least five servings daily? BMC Public Health. 2012;12:280-2458-12-280.

22. Gamm L HL. Rural people 2010-evolving interactive practice. American Journal of Public Health. 2004;94(10):1711-1712.

23. Bellamy GR, Bolin JN, Gamm LD. Rural healthy people 2010, 2020, and beyond: The need goes on. Fam Community Health. 2011;34(2):182-188.

24. Kenny A, Hyett N, Sawtell J, Dickson-Swift V, Farmer J, O'Meara P. Community participation in rural health: A scoping review. BMC Health Serv Res. 2013;13:64-6963-13-64.

25. Strasser RP. Community engagement: A key to successful rural clinical education. Rural Remote Health. 2010;10(3):1543.

26. Morgan A. A national call to action: CDC's 2001 urban and rural health chartbook. J Rural Health. 2002;18(3):382-3.

27. Rural Assistance Center. Rural obesity toolkit. Rural Assistance Center Community Health Gateway Web site. http://www.raconline.org/communityhealth/obesity. Accessed January 5, 2015. 
28. Patterson PD, Moore CG, Probst JC, Shinogle JA. Obesity and physical inactivity in rural america. J Rural Health. 2004;20(2):151-159.

29. Schwartz MB, Brownell KD. Actions necessary to prevent childhood obesity: Creating the climate for change. J Law Med Ethics. 2007;35(1):78-89.

30. Dillon C RC. Rural obesity: Strategies to support rural counties in building capacity. Leadership for Healthy Communities Web site. http://www.leadershipforhealthycommunities.org/images/stories/ruralobesity_naco.pdf. Published 2008. Accessed February 1, 2015.

31. Centers for Disease Control and Prevention. The social-ecological model: A framework for prevention. Injury Prevention \& Control: Division of Violence Prevention Web site. http://www.cdc.gov/violenceprevention/overview/social-ecologicalmodel.html. Published March 25, 2015. Updated 2015. Accessed March 10, 2015.

32. Gombachika BC, Fjeld H, Chirwa E, Sundby J, Malata A, Maluwa A. A social ecological approach to exploring barriers to accessing sexual and reproductive health services among couples living with HIV in southern malawi. ISRN Public Health. 2012.

33. Lantz PM, Viruell-Fuentes E, Israel BA, Softley D, Guzman R. Can communities and academia work together on public health research? evaluation results from a community-based participatory research partnership in detroit. J Urban Health. 2001;78(3):495-507.

34. Frieden TR. A framework for public health action: The health impact pyramid. Am J Public Health. 2010;100(4):590-595.

35. Sallis JF, Owen N, Fisher EB. Ecological models of health behavior. In: Glanz K, Rimer BK, Viswanath K, ed. Health behavior and health education: Theory, research, and practice. Fourth ed. San Francisco CA: Jossey-Bass; 2008:503.

36. DiClemente RJ, Crosby RA, Kegler MC. Theory in health promotion practice and research. In: DiClemente RJ, Crosby RA, Kegler MC, ed. Emerging theories in health and promotion practice and research. Second ed. San Francisco, CA: Jossey-Bass; 2009:4-18.

37. Lantz PM, Viruell-Fuentes E, Israel BA, Softley D, Guzman R. Can communities and academia work together on public health research? evaluation results from a community-based participatory research partnership in detroit. J Urban Health. 2001;78(3):495-507.

38. Davis MM, Aromaa S, McGinnis PB, et al. Engaging the underserved: A process model to mobilize rural community health coalitions as partners in translational research. Clinical and Translational Science. 2014;7(4):300-306.

39. VanDevanter N, Kwon S, Sim SC, Chun K, B Free CEED Coalition, Trinh-Shevrin C. Evaluation of community-academic partnership functioning: Center for the elimination of hepatitis B health disparities. Prog Community Health Partnersh. 2011;5(3):223-233. 
40. El Ansari W. Leadership in community partnerships: South african study and experience. Cent Eur J Public Health. 2012;20(3):174-184.

41. Sandoval JA, Lucero J, Oetzel J, et al. Process and outcome constructs for evaluating community-based participatory research projects: A matrix of existing measures. Health Educ Res. 2012;27(4):680-690.

42. Makhoul J, Nakkash R, Harpham T, Qutteina Y. Community-based participatory research in complex settings: Clean mind-dirty hands. Health Promot Int. 2014;29(3):510-517.

43. Kellogg Health Scholars. Community track overview. Kellogg Health Scholars Web site. http://www.kellogghealthscholars.org/about/community.php. Accessed November 9, 2013.

44. Nyden P. Academic incentives for faculty participation in community-based participatory research. J Gen Intern Med. 2003;18(7):576-585.

45. Krieger JW, Takaro TK, Song L, Weaver M. The seattle-king county healthy homes project: A randomized, controlled trial of a community health worker intervention to decrease exposure to indoor asthma triggers. Am J Public Health. 2005;95(4):652-659.

46. Handley M, Pasick R, Potter M, Oliva E, Nguyen T. Community-engaged research: A quickstart guide for researchers. from the series: UCSF clinical and translational science institute (CTSI) resource manuals and guides to community-engaged research, P. fleisher, ed. Community Engagement Program: Clinical and Translational Institute at University of California, San Francisco. 2010.

47. Horowitz CR, Robinson M, Seifer S. Community-based participatory research from the margin to the mainstream: Are researchers prepared? Circulation. 2009;119(19):2633-2642.

48. MacQueen KM, McLellan E, Metzger DS, Kegeles S, Strauss RP, Scotti R, Blanchard L, Trotter RT. What is community? an evidence-based definition for participatory public health. American Journal of Public Health. 2001;91(12):1929-1938.

49. McDonald M. Practicing community-engaged research. Duke Center for Community Research Web site. https://ccts.osu.edu/sites/default/files/documents/Practicing\%20Communityengaged\%20Research_Training\%20Module.pdf. Published 1997. Updated 1997. Accessed March 1, 2015.

50. Minkler M, Vasquez VB, Warner JR, Steussey H, Facente S. Sowing the seeds for sustainable change: A community-based participatory research partnership for health promotion in indiana, USA and its aftermath. Health Promot Int. 2006;21(4):293-300.

51. Kegler MC, Steckler A, McLeroy K, Malek SH. Factors that contribute to effective community health promotion coalitions: A study of 10 project ASSIST coalitions in north carolina. american stop smoking intervention study for cancer prevention. Health Educ Behav. 1998;25(3):338-353. 
52. Clark NM, Doctor LJ, Friedman AR, et al. Community coalitions to control chronic disease: Allies against asthma as a model and case study. Health Promot Pract. 2006;7(2 Suppl):14S$22 \mathrm{~S}$.

53. Alexander JA, Christianson JB, Hearld LR, Hurley R, Scanlon DP. Challenges of capacity building in multisector community health alliances. Health Educ Behav. 2010;37(5):645-664.

54. Armbruster C, Gale B, Brady J, Thompson N. Perceived ownership in a community coalition. Public Health Nurs. 1999;16(1):17-22.

55. Bornstein DB, Pate RR, Beets MW, Ortaglia A, Saunders RP, Blair SN. New perspective on factors related to coalition success: Novel findings from an investigation of physical activity coalitions across the united states. J Public Health Manag Pract. 2015.

56. Wells R, Ward AJ, Feinberg M, Alexander JA. What motivates people to participate more in community-based coalitions? Am J Community Psychol. 2008;42(1-2):94-104.

57. Barnidge EK, Brownson CA, Baker EA, Shetty G. Tools for building clinic-community partnerships to support chronic disease control and prevention. Diabetes Educ. 2010;36(2):190201.

58. Peterson JW, Lachance LL, Butterfoss FD, et al. Engaging the community in coalition efforts to address childhood asthma. Health Promotion Practice. 2006;7(2 suppl):56S-65S.

59. Kegler MC, Williams CW, Cassell CM, et al. Mobilizing communities for teen pregnancy prevention: Associations between coalition characteristics and perceived accomplishments. $J$ Adolesc Health. 2005;37(3 Suppl):S31-41.

60. Granner ML, Sharpe PA. Evaluating community coalition characteristics and functioning: A summary of measurement tools. Health Educ Res. 2004;19(5):514-532.

61. Michener L, Cook J, Ahmed SM, Yonas MA, Coyne-Beasley T, Aguilar-Gaxiola S. Aligning the goals of community-engaged research: Why and how academic health centers can successfully engage with communities to improve health. Acad Med. 2012;87(3):285-291.

62. Butterfoss FD KM. The community coalition action theory. In: DiClemente RJ, Crosby RA, Kegler MC, ed. Emerging theories in health promotion practice and research. Second ed. San Francisco, CA: Jossey-Bass; 2009:238-275.

63. Viswanathan M, Ammerman A, Eng E, et al. Community-based participatory research: Assessing the evidence. Evid Rep Technol Assess (Summ). 2004;(99)(99):1-8.

64. Jones L, Wells K. Strategies for academic and clinician engagement in communityparticipatory partnered research. JAMA. 2007;297(4):407-410. 
65. Pazoki R, Nabipour I, Seyednezami N, Imami SR. Effects of a community-based healthy heart program on increasing healthy women's physical activity: A randomized controlled trial guided by community-based participatory research (CBPR). BMC Public Health. 2007;7:216.

66. Brownstein JN, Bone LR, Dennison CR, Hill MN, Kim MT, Levine DM. Community health workers as interventionists in the prevention and control of heart disease and stroke. Am J Prev Med. 2005;29(5 Suppl 1):128-133.

67. Parker EA, Israel BA, Robins TG, et al. Evaluation of community action against asthma: A community health worker intervention to improve children's asthma-related health by reducing household environmental triggers for asthma. Health Educ Behav. 2008;35(3):376-395.

68. Becker DM, Yanek LR, Johnson WR,Jr, et al. Impact of a community-based multiple risk factor intervention on cardiovascular risk in black families with a history of premature coronary disease. Circulation. 2005;111(10):1298-1304.

69. Giachello AL, Arron JO, Davis S, Sayad JV, Ramirez D, Nandi C, Ramos C. Reducing diabetes health disparities through community-based participatory action research: The chicago southeast diabetes community action coalition. Public Health Rep. 2003;118:309.

70. Goldfinger JZ, Arniella G, Wylie-Rosett J, Horowitz CR. Project HEAL: Peer education leads to weight loss in harlem. J Health Care Poor Underserved. 2008;19(1):180-192.

71. Trotter RT. Cultural competence series: . communication and community participation in program evaluation processes. DHHS. 1996:241-266.

72. Cargo M MS. The value and challenges of participatory research: Strengthening its practice. Annu Rev Public Health. 2008;29(24):1-26.

73. Themba MN MM. Influencing policy through community-based participatory research. In: Minkler M WN, ed. Community-based participatory research for health. San Francisco, CA: Jossey-Bass; 2003.

74. University of Washington. Definitions, rationale and key principles in CBPR. Developing and sustaining community-based participatory research partnerships: a skill-building curriculum Web site. http://depts.washington.edu/ccph/cbpr/u1/u11.php. Published 2005. Updated 2005. Accessed November 6, 2014.

75. Mensah GA, Dunbar SB. A framework for addressing disparities in cardiovascular health. $J$ Cardiovasc Nurs. 2006;21(6):451-456.

76. Green LW, Mercer SL. Can public health researchers and agencies reconcile the push from funding bodies and the pull from communities? Am J Public Health. 2001;91(12):1926-1929.

77. Start a coalition. CADCA Building drug-free communities Web site. http://www.cadca.org/start-coalition. Accessed March 1, 2015. 
78. Kegler MC, Swan DW. Advancing coalition theory: The effect of coalition factors on community capacity mediated by member engagement. Health Educ Res. 2012;27(4):572-584.

79. Sadler LS, Larson J, Bouregy S, et al. Community-university partnerships in communitybased research. Prog Community Health Partnersh. 2012;6(4):463-469.

80. U.S. Department of Health and Human Services. Developing a conceptual framework to assess the sustainabilityof community coalitions post-federal funding. 2010.

81. Zakocs RC, Guckenburg S. What coalition factors foster community capacity? lessons learned from the fighting back initiative. Health Educ Behav. 2007;34(2):354-375.

82. Zakocs RC, Edwards EM. What explains community coalition effectiveness?: A review of the literature. Am J Prev Med. 2006;30(4):351-361.

83. Kenney E SS. Coalition self-assessment survey . B C School of Public AffairsSurvey B C School of Public Affairs New York, NY: City University of New York. 2002.

84. Foster-Fishman PG, Berkowitz SL, Lounsbury DW, Jacobson S, Allen NA. Building collaborative capacity in community coalitions: A review and integrative framework. Am J Community Psychol. 2001;29(2):241-261.

85. Clark NM, Lachance L, Doctor LJ, et al. Policy and system change and community coalitions: Outcomes from allies against asthma. Health Education \& Behavior. 2014;41(5):528538.

86. Schulz A, Israel BA, Lantz P. Instrument for evaluating dimensions of group dynamics within community-based participatory research partnerships. Eval Program Plann. 2003;26:249262. 


\section{Chapter 5 - Field Experience}

My public health field experience was completed with HealthKind, a 501(c)(3) non-profit organization located within the Posner Center for International Development in Denver, Colorado. I dedicated one hundred and eighty hours to HealthKind between May 19 and July 21, 2014.

HealthKind is a small non-profit organization focused on health and development. The group works for and alongside South Sudanese nationals living in the U.S. in an effort to bring sustainable, community-based and integrative health initiatives to their home country. Initiatives focus on health education, health-worker education, and delivery of services. Founded in 2008 by Rhonda Parmley (Program Director) and Kuier Atem Deng (Country Liason), HealthKind is staffed with seven part-time workers and managed by an advisory board of eleven global health professionals. Four members on staff were South Sudanese refugees who are now active in the diaspora community in Denver.

The organization commonly collaborates with other non-profit organizations and policy groups that have a shared interest in improving global health disparities. The characteristic that sets HealthKind apart from other like organizations is their employ of a CEnR approach in addressing the complex health problems that plague South Sudan. By engaging the South Sudanese diaspora community through a grassroots approach, HealthKind is better equipped to identify problems and create health interventions that are both evidence-based and socioculturally appropriate. Current initiatives include the goal to build a health clinic in Kongor, located in Twic East County of the Jonglei State. Ultimately, the aim is to recruit and train South

\footnotetext{
$\$$ Diaspora, defined as "people settled far from their ancestral homelands, ${ }^{20 "}$ is the proper term used to describe former refugee populations that have settled abroad.
} 
Sudanese living in the U.S. to act as on-the-ground trainers in their native country to both build the healthcare workforce and staff the HealthKind clinic. The goal of the HealthKind clinic is ultimately to serve as a conduit for health initiatives in the country.

While in Denver, I worked directly with the Program Director. Dr. Rhonda Parmley holds a Ph.D. in Education and Human Resource Studies, is an Instructor of Women's Studies at Front Range Community College, and is a guest lecturer on Global Issues in Women's Health at the Colorado School of Public Health. She is also a Licensed Professional Counselor. As the Program Director and Co-Founder of HealthKind, Dr. Parmley manages all organizational activities from networking to implementing the organization's programs on the ground. I felt honored to be selected as a practicum student with HealthKind, as global health and community development are fields of special interest to me. Additionally, I believed that my public health education would benefit greatly. Throughout my field experience, I was involved in all aspects of running a global non-profit organization - an experience that was both educational and enlightening.

\section{South Sudan}

The Republic of South Sudan, with a population of approximately 11.6 million, ${ }^{1}$ is the world's newest country. South Sudan seceded from Sudan on January 9, 2011, after persistent and aggravated conflict with the Arab-ruled northern capital of Khartoum. At war between 1955 and 1972, and then again between 1983 and 2005, ${ }^{1}$ massive numbers of civilian lives were lost.

Though gaining independence in July 2011, South Sudan continues to struggle. In particular, conflict between two leading tribes, the Dinka and the Nuer, ${ }^{2}$ has caused yet another civil war to plague the country. To make matters worse, Sudan remains hostile to its sister country over oil profits, resulting in the closure of oil operations in South Sudan- a move that has 
proved to be economically devastating to the fledgling country. ${ }^{3}$ South Sudan has been at war for the past 56 years $^{3}$ and there appears no end in sight.

An estimated 2.5 million inhabitants were killed during the first and second civil wars; ${ }^{2}$ millions more were displaced - many of them children (an estimated 20,000) who fled on foot without any family. ${ }^{4}$ In refugee camps, aid workers named these children the "Lost Boys of Sudan," a term that has persisted, inspiring numerous films and books based on the special group of refugees. ${ }^{5}$ In 2001, nearly 4,000 "Lost Boys" settled in the United States seeking amnesty. ${ }^{4}$

The leaders of North and South Sudan signed a Comprehensive Peace Agreement in $2005,{ }^{2}$ opening the door for all Sudanese nationals displaced worldwide to return home. ${ }^{3}$ In response, many survivors have returned to help rebuild the new country and to provide aid. ${ }^{6}$ However, the struggle is far from over. In January 2014, the International Crisis Group estimated that the Dinka-Nuer hostility has claimed over 10,000 lives and displaced 1.5 million inhabitants within the country ${ }^{7}$. An additional 500,000 have fled to neighboring countries seeking refuge. ${ }^{8}$ On April 3, 2014, President Barack Obama declared the situation in South Sudan a national emergency, addressing the "situation in and in relation to South Sudan, which has been marked by activities that threaten the peace, security, or stability of South Sudan and the surrounding region, including widespread violence and atrocities, human rights abuses, recruitment and use of child soldiers, attacks on peacekeepers, and obstruction of humanitarian operations." These comments were extended one year later, in $2015 .{ }^{9}$ In response, the United Nations has graded the crisis a Level 3 humanitarian emergency, ${ }^{8}$ thereby requiring a significant response from the humanitarian sector.

According to the WHO, South Sudan claims some of the worst health indicators worldwide. Maternal mortality historically ranks among the highest in the world, with 2,054 
deaths per 100,000 pregnancies. ${ }^{10}$ This figure may be due to inadequate training of health personnel and facilities, lack of family planning (only $4 \%$ of women reported using contraception, $)^{11}$ and a high teen pregnancy rate. Teenage mothers account for up to $30 \%$ of maternal deaths. ${ }^{12}$

The mortality rate for infants was last measured to be 64 per 1,000 live births, and the mortality rate of children under-five is 99 per 1,000 children. ${ }^{11}$ These astounding numbers may be linked to the high rates of communicable diseases in South Sudan, including malaria, tuberculosis, and HIV/AIDS. South Sudan contends with $90 \%$ of the world's guinea-worm disease burden while also combating myriad other parasitic diseases such as leishmaniasis, trypanosomiasis, onchocerciasis, trachoma, lymphatic filariasis, and schistosomiasis. ${ }^{11}$ Although half of the population has access to water sources (57\%), a mere $9 \%$ have access to proper sanitation. ${ }^{11}$ Considering the high rates of poverty, malnutrition, and internally displaced persons, South Sudan is particularly susceptible to epidemic-prone diseases. ${ }^{11}$ Most recently, from May to November 2014, South Sudan struggled with a cholera outbreak. ${ }^{8}$

South Sudan's long-standing public health crisis is primarily related to a lack of access. ${ }^{13}$ At this time, only $25 \%$ of the population has access to medical care, ${ }^{14}$ due to the absence of facilities, financial constraints, and cultural barriers. ${ }^{14}$ Preventive measures as simple as insecticide-treated bed nets are available to only $20 \%$ of the population. ${ }^{8}$ Persistent civil wars have rendered South Sudan's health infrastructure obsolete, and non-government organizations (NGOs) are responsible for up to $80 \%$ of the delivery of health services. ${ }^{11}$ In 2012, the Center for Strategic and International Studies released a report highlighting the need for the United States government and concerned aid agencies to identify novel approaches to building a sustainable health system in order to address the numerous health problems impacting South Sudan. ${ }^{13}$ 
Sustainable programs are particularly impactful, as emergent (and short-term) assistance does not translate to long-term public health improvements. ${ }^{13}$

\section{Scope of Work}

As a recently formed non-profit organization, HealthKind remains in the formation and planning stages of development. Without the efforts of full-time staff, it has been particularly difficult for this organization to launch humanitarian health initiatives on a global scale. As a Public Health student, I was recruited to springboard the organizational development of HealthKind.

Identifying and securing funds to support their mission is critical to the success of any global non-profit organization. Before I started, Dr. Parmley had already identified two funding avenues to target: a grant from a private philanthropy and support from the United States Agency for International Development (USAID).

The Chatlos Foundation is a philanthropic organization that funds non-profits aligning with their areas of interest, including Bible colleges/seminaries, religious issues, medical concerns, and sociocultural concerns. ${ }^{15}$ The Foundation's efforts extend across the United States and globally.

USAID's Office of Maternal and Child Health was seeking concept papers to support the implementation of their Emerging Priorities in Reproductive, Maternal and Newborn Health (RMNH) project. The program's outreach targeted South Sudan and 23 other priority countries.

Drafting the concept paper granted me the opportunity to participate in the planning and developing a health relief project from the ground-up.

In addition to spearheading the two funding opportunities described above, I was also charged with identifying additional avenues of sponsorship. While with HealthKind, I applied for 
the Grand Challenge Exploration grant from the Grand Challenges in Global Health family of programs that focuses on improving health in the developing world ${ }^{16}$. In addition to applying for external funding, I coordinated "Peace for South Sudan," HealthKind's first fundraising dinner and silent auction. The event was held on July 26, 2014 at the Posner Center for International Development in Denver.

Networking is another key component to growing a global non-profit organization. HealthKind's offices are based out of the Posner Center, a complex that houses over 60 development-oriented companies and organizations. The Center was created to leverage the intellectual capital of numerous like-minded organizations under one roof. Specifically, the creators hoped to bring together groups with similar interests and goals to promote "cross-pollination" - the exchange of ideas to enhance the collective capacity required to address the challenges of global development. ${ }^{17}$ As the only member of the HealthKind team stationed in Denver, it was important that I work at the Posner Center, participate in the activities designed to promote idea-sharing and cultivate relationships with other organizations.

I also networked outside of the Posner Center, attending a relevant press conference at the Colorado state capitol and establishing connections with highly visible and interested parties. These persons included Andrew Romanoff, a politician and senior advisor of International Development Enterprises, and Tamara Banks, an Emmy Award-winning journalist.

Lastly, I supported HealthKind's ongoing programs and initiatives. "Women Cry for Peace and Life," the organization's monthly group gathering, brought together women from the South Sudanese diaspora to discuss how health initiatives might better address concerns in that country. Facilitated by Dr. Parmley and Jill Cantor Lee, a co-founder of Mediators Without 
Borders, these meetings served as a forum for HealthKind to engage and collaborate with stakeholders in the community.

Overall, my scope of work at HealthKind was broad but aligned well with my interest in global health and community engagement. I experienced all aspects of the management of a global non-profit organization, from struggle to success.

\section{Learning Objectives}

HealthKind's slogan is "Sustaining Health. Strengthening Community.", and I was eager to support this mission by utilizing the skill set I gained from the Master of Public Health curriculum. My primary learning objective was to learn how to implement and manage novel health programs in global health. This goal was achieved, but not in the way I anticipated. I prepared myself for experience in monitoring and evaluating ongoing health programs; what I encountered, however, was the struggle to execute even a novel, well-planned health program. Watching HealthKind function from the base-level taught me that extensive time, planning, and funding is necessary to implement global health initiatives and to keep them "afloat." I experienced many aspects of implementing and managing global health programs, from the difficulties involved with collaborating alongside culturally distinct community partners, to designing every detail of a proposed health program aimed at enhancing maternal and child health. Despite my expectations, I discovered an alternative side to implementing and managing global health programs; this experience was essential to understanding how public health functions in reality (versus the theoretical manner in which it is described in textbooks).

My second objective was to develop materials for global health advocacy, and I accomplished this task by coordinating the monthly "Women Cry for Peace and Life" gatherings. During these sessions, we brainstormed possible health interventions targeting the myriad issues 
that these women battled on a daily basis. Topics ranged from covert contraceptive delivery to procuring and distributing shoes to children in South Sudan. We then utilized these plans in our grant applications.

In my opinion, the most important learning objective was to better understand the barriers facing global health practice in the non-profit setting. Prior to working with HealthKind, I envisioned a future that included working for a global non-profit organization to alleviate health disparities worldwide. The opportunity to work with HealthKind was appealing because it offered real world experience in this field. In particular, I was happy to join HealthKind at a time when the organization was still in its infancy: it granted me the "whole picture" of non-profit work, rather than a snapshot of an already well-established organization. Today, I better understand the extensive resources required for non-profit work (not only in the development stage, but continuously to ensure the organization's mission can be sustained).

\section{Activities Performed}

From my first conversation with Dr. Parmley, I was immediately included in the numerous activities that HealthKind had planned to launch the organization's sustainable health programs.

\section{Grant Applications}

Prior to joining HealthKind, I had worked under the purview of grants but had never actually been involved with the grant application process. While in Denver, I collaborated with Dr. Parmley and Heidi Becksted, another public health student, to draft several grant applications. Inherent to the process was the need to ensure that HealthKind met grant-specific criteria and developed realistic objectives for the organization's programs. 
For the Chatlos Foundation, I wrote an application to secure financial support for HealthKind's monthly "Women Cry for Peace and Life" gathering. The program was operated on volunteer time, and the cost of refreshments was debited directly from the Program Director's personal accounts. HealthKind desired to expand these monthly discussions and to develop a separate session for male participants. I suggested that we provide an incentive for participants who attended and that we hire a translator to assist with communication. With adequate funding, we could also compensate group facilitators who would function as mediators. I created a budget for the expanded program and requested $\$ 14,040$ to fund these efforts for one year. The application was submitted on May 24, 2014.

The most challenging and intensive grant was the concept paper submitted to USAID's Emerging Priorities in RMNH initiative. After reviewing the program's guidelines, I initiated contact with USAID's Agreement Officer to gauge the level of interest in HealthKind's initiatives and to introduce our organization. I then coordinated with Dr. Parmley, Beverly Lyne (a public health nurse and a member of the HealthKind Board of Directors), and Heidi to design our concept. In June, 2014, after an intensive week of research, brainstorming, and ideamapping, we developed an evidence-based action plan that addressed maternal mortality in South Sudan. The concept employed a combination of community-engaged research (CEnR) and train-the-trainer approaches. As HealthKind is a small non-profit organization, I located established sub-partners to support the program's initiatives. Specifically, I established contacts at Management and Training Corporation (MTC) in Washington, D.C. to discuss a joint effort to train maternal healthcare workers in the U.S. Next I developed the program's budget -a large undertaking considering the grant awarded up to $\$ 5$ million over five years. To qualify, every facet of the project must be accounted for, from staff salaries to the cost of providing blankets for 
a health clinic in Kongor. I even included a line item for the procurement cost of helicopters to transport workers to inaccessible villages in the South Sudanese countryside! Once completed, I finalized the concept paper (entitled "Strengthening Maternal Health in Rural South Sudan”) and incorporated any suggestions made by HealthKind's Advisory Board. Dr. Parmley submitted the concept paper to USAID on July 9, 2014.

Throughout the summer, I researched grants that aligned with HealthKind's funding needs. During my first conversation with the Program Director, Dr. Parmley described a vision to create a set of educational modules focused on maternal and child health. So, an anticipated activity of mine was "developing health education programs for limited resource settings." The curriculum, to be delivered on solar-powered tablets, was intended for dispersion in South Sudan. However, a lack of adequate funding stalled the development of this series. I proposed that the Grand Challenges Exploration application be used to fund this initiative. Funding was requested to hire ground personnel, a software developer, videographer, equipment procurement and travel to South Sudan. In total, the budget called for $\$ 98,950$ in funding, and the application was submitted on August 1, 2014.

\section{Annual Fundraising Dinner and Silent Auction}

HealthKind's first fundraising dinner and silent auction, "Peace for South Sudan," was held on July 26, 2014. Only the date and location had been solidified prior to my arrival. I coordinated with two HealthKind interns, Nurta and Kaylan, to plan, market, and host this event. One of the most difficult aspects of planning was to find sponsors and develop effective marketing materials. Our target audience was groups and individuals that were both passionate about achieving peace in South Sudan and financially equipped to contribute to this cause. Unfortunately, these two characteristics do not always go hand-in-hand. 
I reached out to specific non-profit organizations and public advocates with a track record of promoting international development. I managed HealthKind's Facebook account and used it as a forum for advertising. I was also charged with managing HealthKind's email-based marketing program, Constant Contact, to connect with individuals that had previously demonstrated interest in HealthKind's mission. I designed posters and flyers that I distributed to local businesses. I also reached out to local media outlets and newspapers. As the event approached, I planned the menu and even procured a substantial donation from Coors Brewing Company to provide beverages. I obtained event insurance and facilitated the silent auction by soliciting business owners in the Denver metro area. Silent auction offerings included certificates for massage packages, baked items, gym memberships, jewelry, clothing items, and food baskets. The night of the event, the HealthKind team and I decorated the venue with traditional Sudanese regalia. I managed the bar and developed a wristband system for tracking beverages. A professional photographer attended to document the evening. In total, approximately 75 people attended the event.

\section{Community Engagement}

HealthKind's dedication to community involvement forms the foundation of the organization's mission. During my time there, I coordinated three Women Cry for Peace and Life group gatherings. I prepared the dedicated space in the Posner Center with chairs and couches and provided snacks and refreshments. I took notes at these gatherings and compiled a list of possible initiatives for HealthKind to pursue. I utilized HealthKind's Facebook account and leveraged that forum to connect the international development community and the South Sudanese diaspora in order to facilitate dialog between these two stakeholders. 


\section{Products Developed}

I updated HealthKind's Executive Summary (Appendix D) to include the most recent statistics and program goals. This version was available at the Peace for South Sudan dinner, and it has been used as a brochure at numerous health conferences since that time.

Although it is difficult to claim a completed grant application as a product per se, I feel strongly that the concept paper submitted to USAID included a health program that would be very successful with the appropriate funding.

I developed marketing materials for the Peace for South Sudan fundraising dinner, including HealthKind brand t-shirts (Figure 5.1), a banner, and posters (Figure 5.2). The shirts were available for purchase at the dinner and at Walk for Sudan, an annual walk to raise funds for the Nuba Water Project (a partnering non-profit organization based in Denver).

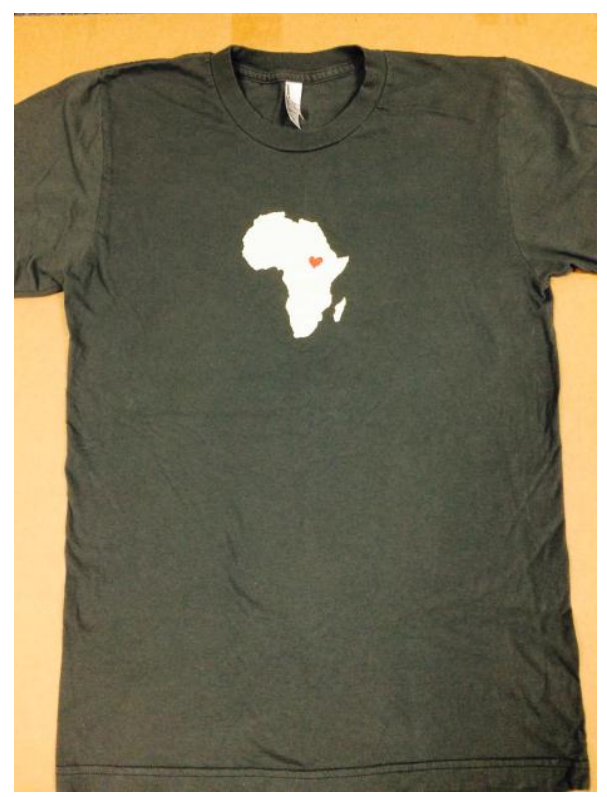

Figure 5.1 HealthKind brand tshirts

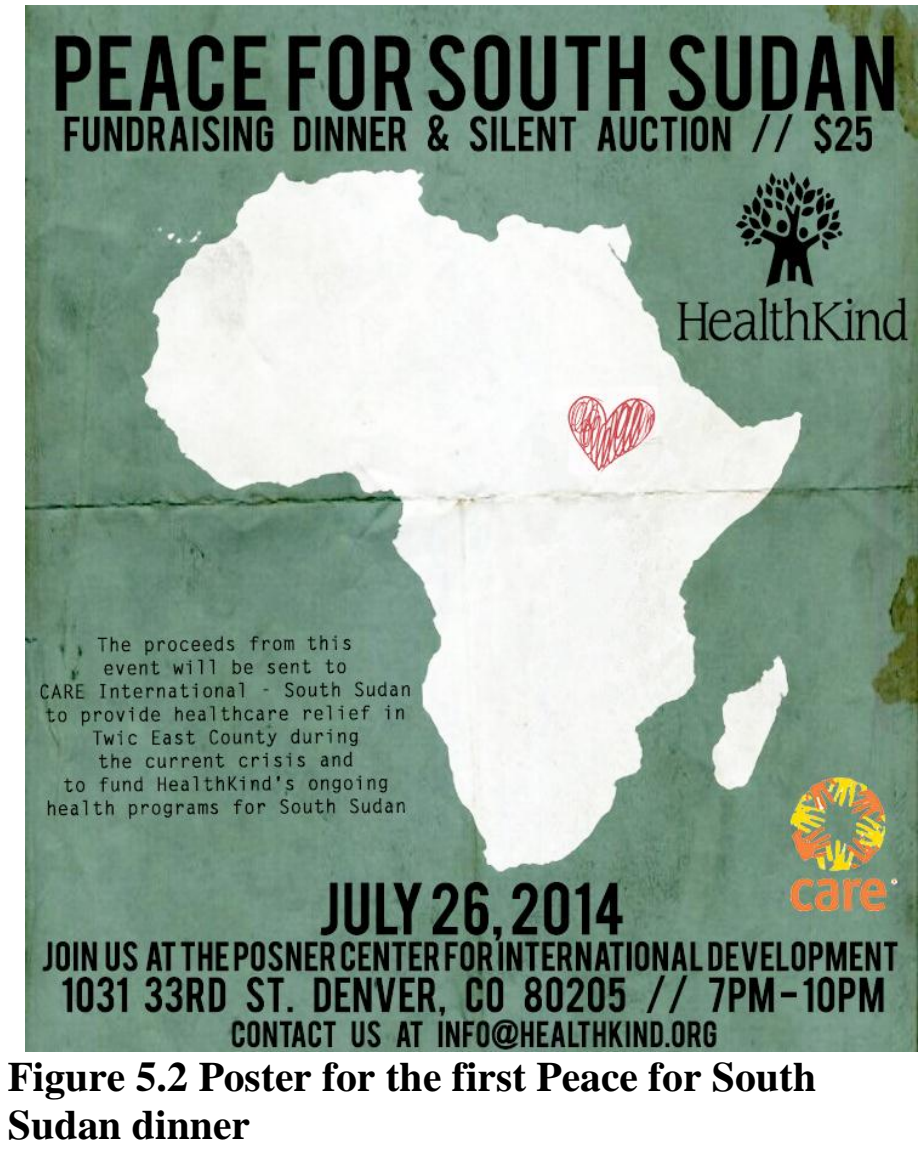




\section{Alignment with Public Health Core Competencies}

Throughout my thesis research and field experience, I have gained unmeasurable insight into each of the public health core competencies.

One essential competency in my public health practice has been biostatistics. In assembling HealthKind's Executive Summary and compiling data for grant applications, this discipline has been critical to my understanding of the descriptive and informatics techniques used to report vital statistics, records, and public health characteristics. For my thesis research, I needed to distinguish between different statistical measures; a strong knowledge of these measures was essential to aggregate, analyze, and interpret the results of the literature. Additionally, it was important to understand the most appropriate statistical method to be utilized (or not) in each circumstance, and why. As with many skills, I found the more I practiced biostatistics, the greater understanding I had for the topic.

As I was developing health interventions set in rural South Sudan, environmental health sciences, the second core competency, was an important consideration. I considered exposure to various environmental hazards specific to the setting, notably access to potable water, sanitation methods, and the implications of having internally displaced persons in aid camps for long periods of time. Recently, WHO released a report on the public health threat of contaminated foods in the African region, ${ }^{18}$ which is an environmental health concern typically overlooked in food insecure areas. Additionally, I explored environmental health risk in my thesis research as well. My data were derived from a multi-state childhood obesity grant. Since obesity may be at least in part a physiological response to a built environment, ${ }^{19}$ I explored environmental health sciences in my research as well. 
The application of epidemiological principles was also essential to my work at HealthKind and in writing my thesis. Understanding epidemiologic data from rural communities in the U.S. and South Sudan was necessary to comprehend the scope and breadth of these problems and to provide a justification for public health intervention. It was important that I understand what prevalence represents because the data from each community studied measured the prevalence of specific health conditions or disease. Epidemiologic knowledge was also necessary for my evaluation of the literature: it helped me gauge the strength and limitations of the available data in my area of focus. Since community-based public health occurs on a large scale, I gained experience in conceptualizing the dissemination of epidemiologic data.

Health services administration was the most important core competency utilized in my thesis and field experience. By engaging communities in public health initiatives, we focused on increasing access to care in regions where health systems simply do not exist. Understanding the impact that the accessibility of healthcare can have on rural populations, and how we address such issues via public health, is the underlying foundation of my education.

Social and behavioral sciences were strongly aligned with my thesis. The grant from which my thesis originates was designed around Ecological Model for Childhood Overweight (Figure 5-3). The aim of the grant is to account for the multiple effects of social and cultural elements of the environment. Additionally, the Community Coalition Action Theory, the concept in which my thesis is rooted, describes social and behavioral constructs of coalition functioning that may promote the successful implementation of health activities. It was important to consider the cultural component of social and behavioral factors since they differ according to each setting and may have profound implications for health status. 


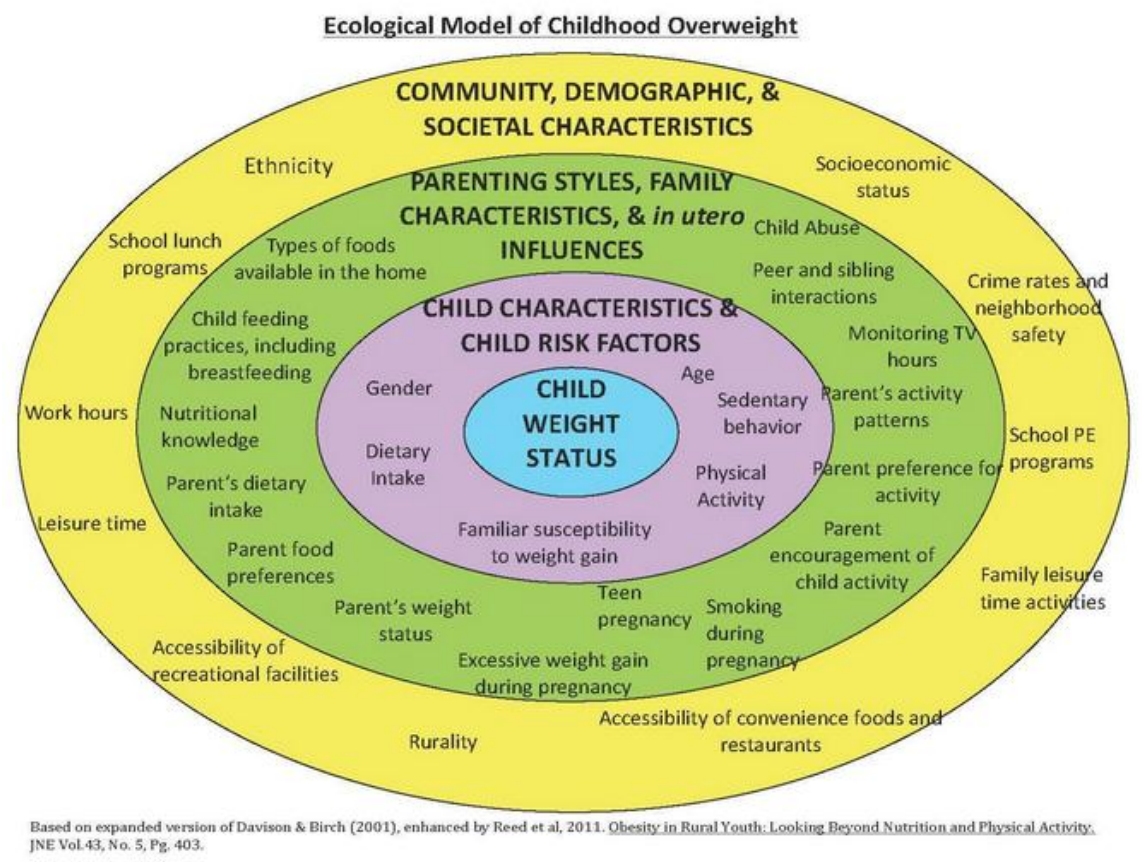

Figure 5.3 Ecological Model of Childhood Overweight

\section{Conclusions}

Since enrolling in my first public health class, a step I took simply out of curiosity, I have been hooked on the idea that health begins and ends with community. The concept that health occurs on a larger scale was novel to my traditional background in healthcare. It inspired me that public health practitioners can provide resources for communities to act as catalysts for positive change. At this nexus, I identified the common ground between my thesis research and my field experience. When researchers/healthcare providers partner with stakeholders who care most about a problem, they will be better prepared to address these issues as a united force.

Throughout my public health education at Kansas State University, I have been consistently challenged to think in these terms, and I am eager to share the knowledge and skills attained to practice healthcare holistically. 


\section{References}

1. Central Intelligence Agency. Africa: South Sudan. The World Factbook Web site. https://www.cia.gov/library/publications/the-world-factbook/geos/od.html. Published June 20 2014. Updated 2014. Accessed March 20, 2015.

2. Verini J. How the world's youngest nation descended into bloody civil war. National Geographic. 2014(10).

3. Gettleman J. New wave of 'Lost boys' flee Sudan's lingering war. New York Times. 2012.

4. International Rescue Committee. The lost boys of Sudan. International Rescue Committee News Web site. http://www.rescue.org/blog/lost-boys-sudan. Updated 2014. Accessed April 3, 2015.

5. Philippe Falardeau. The Good Lie. 2014.

6. Alliance for the Lost Boys of Sudan. History of the lost boys. Alliance for the Lost Boys of Sudan Web site. http://www.allianceforthelostboys.com/about-us/. Updated 2014. Accessed April 3, 2015.

7. Kulish N. New estimate sharply raises death toll in South Sudan. New York Times. 2014:A6.

8. World Health Organization. Situation report: South Sudan. 2015;47.

9. The White House. Notice -- continuation of the national emergency with respect to South Sudan. 2015(March 31 2015).

10. World Health Organization. Country cooperation strategy: South Sudan. 2014;14.03.

11. The World Bank. South Sudan. The World Bank Data By Country Web site. http://data.worldbank.org/country/south-sudan. Updated 2013. Accessed April 3, 2015.

12. Doki C. South Sudan child marriages at devastating high. The World Post Web site. http://www.huffingtonpost.com/2013/03/08/south-sudan-child-marriages_n_2836793.html. Published March 8 2013. Updated 2013. Accessed April 3, 2015.

13. Downie R. The state of public health in South Sudan - critical condition. CSIS Global Health Policy Center. 2012.

14. HealthKind. Issues we face. HealthKind Web site. http://www.healthkind.org/. Published July 2014. Updated 2014. Accessed April 2, 2015.

15. The Chatlos Foundation. Information for applicants. Chatlos Foundation Web site. http://chatlos.org/AppInfo.htm\#. Accessed April 6, 2015. 
16. Grand Challenges in Global Health. Grand challenges explorations. Introduction: Grand Challenges Explorations Web site.

http://gcgh.grandchallenges.org/Explorations/Pages/Introduction.aspx. Accessed April 7, 2015.

17. Posner Center for International Development. Mission and vision. Posner Center Web site. http://posnercenter.org/about/mission-and-vision/. Published 2014. Updated 2014. Accessed April 7, 2015.

18. World Health Organization. Unsafe food: A major health threat in the african region. World Health Organization Media Centre Web site. http://www.afro.who.int/en/media-centre/afrofeature/item/7517-unsafe-food-a-major-health-threat-in-the-african-region.html. Published April 6 2015. Updated 2015. Accessed April 6, 2015.

19. Schwartz MB, Brownell KD. Actions necessary to prevent childhood obesity: Creating the climate for change. J Law Med Ethics. 2007;35(1):78-89.

20. Merriam-Webster. Definition: Diaspora. Merriam-Webster Online Dictionary Web site. http://www.merriam-webster.com/dictionary/diaspora. Updated 2015. Accessed April 7, 2015. 


\section{Appendix A - Community Application}

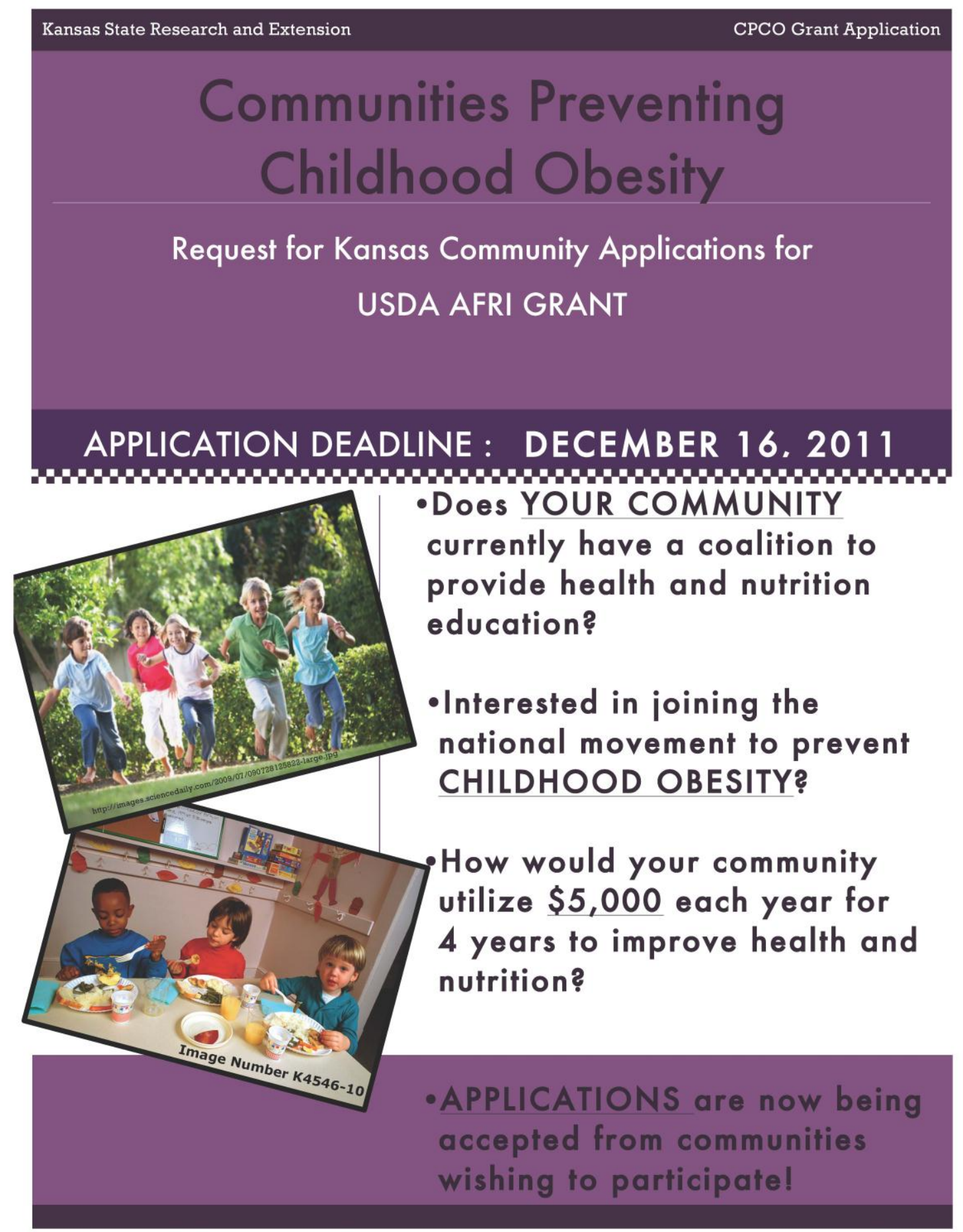




\section{Expectations of Selected Communities:}

- Participation in quarterly project conference calls

- Participation in training, as applicable

- Community planning and implementation of interventions

- Project reports (For example: progress of activities, fiscal reports, and relevant others asked by CPCO leaders)

- Commitment of participation for 4 years (2012 - 2016)

\section{Required Application Components:}

- Letter of support from county/district director for participation in the project

- Letter of support from community coalition leader (chair/president/director)

- Note: Letters of support can be sent by regular mail to the below address if they cannot be emailed or scanned.

Melissa Taylor, KS CPCO Project Assistant

Department of Human Nutrition

Justin Hall 244

Kansas State University

Manhattan, KS 66506-1407

- A Word document (limit 5 pages) thoroughly answering all questions listed in the Application Questions section below.

\section{Application Questions:}

1. Name and contact information of the community/county coalition leader?

2. What is the name of the community coalition?

3. How long has the coalition been active?

4. Who are the coalition members: (Name of members, affiliations, and any other relevant information)?

5. What are the 3-5 main objectives/activities of the coalition?

6. Have the Extension Educator and/or the community coalition received any grants in the past 5 years? If so, please describe.

7. Why is the coalition interested in the topic of childhood obesity?

8. What (if any) previous or current work has the coalition done related to obesity?

9. What other programs/efforts have you, the applicant, done in your county/community related to obesity? 


\section{Application Questions Continued:}

10. If your coalition participated in a similar program (i.e., targeted at 4-year-olds or early childhood), how many participants did your coalition and program have?

11. What is your coalition's current access to 4-year-old children and people who provide care for them?

12. Will any additional resources be used to help this project succeed? If so, what is the additional funding?

13. What challenges or barriers do you foresee that might hinder the project's success in your county?

\section{Funding Guidelines:}

Grant funding CAN be used for:

- Marketing, advertisement, and media campaign items to promote childhood obesity prevention

- Evidence-based curriculum purchase, training and implementation

- Costs related to project organizational meetings (i.e., materials, refreshments, facilities, supplies)

- Recruitment, involvement, and recognition of project partners

- Travel, lodging, per diem, incidentals to attend training, meetings, conferences related to childhood obesity prevention

- Office supplies associated with the planning, promotion, completion, and reporting of the project

- Communication (i.e., phone, fax, post-mail)

- Event costs (i.e., rentals, event insurance, temporary staff, transportation)

- Incentives for participants (i.e., gift cards, games, toys)

Grant funding CANNOT be used for:

- Purchase of office equipment (i.e., computers, desks, chairs, etc.)

- Costs incurred for vendor programs, materials, and supplies that lack evidence of effectiveness (Note: Even if supplies are evidence-based, if they are not listed in the toolkit, they cannot be paid for out of the grant)

- Supplementing of other funds (i.e., using funds to pay for ongoing administrative costs or personnel)

- Indirect fees or administrative costs

- Membership fees, dues

- Costs related to evaluation (i.e., measurement devices like scales, Stadiometers) 


\title{
Appendix B - Coalition Self-Assessment Survey
}

\section{Coalition Self-Assessment Survey}

\author{
COALITION NAME
}

\section{Date}

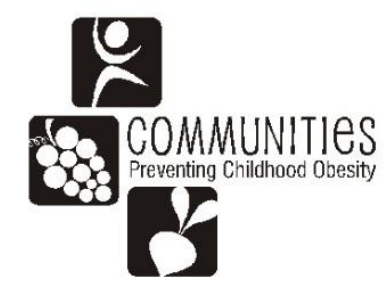

\section{INSTRUCTIONS FOR RESPONDENTS}

Please answer questions as they pertain to your involvement since joining the coalition. If you are new to this coalition, please answer to the best of your ability based on your perspective of the meetings you've attended.

\section{Sample Question}

S1. Please circle a number for each answer as in the sample answer:
(no
2. yes

Developed by: Erin Kenney, Ph.D. and Shoshanna Sofaer, Dr.PH. School of Public Affairs, Baruch College, City University of New York, 2000.

Adapted by Communities Preventing Childhood Obesity, 2012.

For use and/or adaptations of this document, please credit Erin Kenney, Ph.D. and Shoshanna Sofaer, Dr.PH., School of Public Affairs, Baruch College, City University of New York, 2000 


\section{ROLE IN COALITION}

Q1. What is your role in the coalition? Circle more than one response, if appropriate.

CoalitionRoleA. Member of the steering or executive committee

CoalitionRoleB. Coalition chair or officer

CoalitionRoleC. Chair/co-chair of a coalition committee or task force

CoalitionRoleD. Committee member

CoalitionRoleE. Member (no other responsibility)

CoalitionRoleF. Staff

CoalitionRoleG. Other

Q2. Are you part of the coalition as an individual member or as a representative of an organization? Please circle either 1 or 2 , or both, if appropriate.

1. Individual Member, not representing an organization

2. Representative of an organization

3. Both

Q2a. If you are an individual member not representing an organization, please specify your role (for example, "parent")

Q2b. If you are an individual member not representing an organization, how long have you been an individual member of the coalition?
YEARS
MONTHS
DON'T KNOW
NOT APPLICABLE

Q3. If you represent an organization, please indicate the one that best describes the Organization you represent in this coalition. Please circle only one.

1. Community Health Center/Community clinic

2. Community/neighborhood group

3. Ethnic and minority group organization

4. Youth organization

5. Parent organization

6. Women's organization

7. Religious/Faith-based organization

8. Housing organization

9. Environmental advocacy group

10. Environmental agency

11. Voluntary agency that has obesity as a key part of their mission

12. Other voluntary agency

13. Other community-based organization

14. Other coalition

15. After school program/Parks and recreation

16. Day care/Preschool/Head Start center

17. School (any grades K-12)

18. Academic institution (college/university)

19. HMO and other managed care organization 
20. Medicaid and other insurers

21. Pharmaceutical company

22. Hospital

23. Health care provider organization (non-hospital)

24. Physician practice

25. Local health department

26. State health department

27. Business

28. Media

29. Legislative office

Q3other. Other (please specify)

Q4. If a representative of an organization, how long has your organization been represented in the coalition?

YEARS __ MONTHS ___ DON'T KNOW _ NOT APPLICABLE

Q5. Please circle the role that fits you best. Circle only one.

Q5spec. Physician, please specify

2. Physician assistant

3. Nurse/nurse practitioner

4. Respiratory therapist

5. Social worker/case worker

6. Case manager

7. Community health worker

8. Outreach worker

9. Health educator

Q5spec. Other health professional, please specify

11. Day care/Head Start provider

12. After school/parks and recreation provider

13. Government official/staff

14. Parent/caregiver

15. Staff from non-profit

16. Administrator

17. Researcher/evaluator

Q5spec. Other, please specify

\section{INCLUSION, RECRUITMENT, MEMBERSHIP}

Q6. In your opinion, does your coalition have sufficient representation from groups, organizations, and/or schools in your community to accomplish the objectives of the coalition?
1. No
2. Yes
3. Don't Know

Q6a. If you answered "no" above, in your opinion, which type of the following groups, organizations and/or schools listed are NOT well represented on the coalition? Circle all that apply. 
Q6a1. Community Health Center/Community clinic

Q6a2. Community/neighborhood council or advisory group

Q6a3. Ethnic and minority group organization

Q6a4. Youth organization

Q6a5. Parent organization

Q6a6. Women's organization

Q6a7. Religious/Faith-based organization

Q6a8. Housing organization

Q6a9. Environmental advocacy group

Q6a10. Environmental agency

Q6a11. Voluntary agency that has childhood obesity as a key part of their mission

Q6a12. Other voluntary agency

Q6a13. Other community-based organization

Q6a14. Other coalition

Q6a15. After school program/Parks and recreation

Q6a16. Day care/Preschool/Head Start center

Q6a17. School K-12

Q6a18. Academic institution (college/university)

Q6a19. HMO and other managed care organization

Q6a20. Medicaid and other insurers

Q6a21. Pharmaceutical company

Q6a22. Hospital

Q6a23. Health care provider organization (non-hospital)

Q6a24. Physician practice

Q6a25. Local health department

Q6a26. State health department

Q6a27. Business

Q6a28. Media

Q6a29. Legislative office

Q6a30. Parents/caregivers of 4-year old children

Q6a31. Other (please specify)

Q6a32. None of the above

Q6b. If you have circled one or more groups above as being not well represented, please select the SINGLE group you think is most important to add to the coalition at this time. Write the number of the group on this line

Q6c. Why do you think the group identified as most important to add to the coalition is not well represented at this time? (CIRCLE ALL THAT APPLY):

Q6c1. The coalition never tried to involve them

Q6c2. The coalition invited them but they chose not to participate

Q6c3. They used to participate but dropped out

Q6c4. The coalition cannot get access to representatives of this group

Q6c5. The coalition as a whole is not sure that this group should be asked to join

Q6c6. Resources are lacking to recruit new members

Q6c7. Some coalition members do not want to share power with this group

Q6c8. Don't know 
Q7. Is your coalition actively recruiting new members?
1. No
2. Yes
3. Don't know

Q8. In your opinion, do new members receive adequate orientation to be effective members of the coalition?
1. No
2. Yes
3. Don't know

Q9. Of those that represent organizations, please circle the number which best represents your opinion about the number of members who participate in your coalition who have enough authority to make commitments of resources or other support for the coalition.

1. Less than one-quarter of the members

2. Less than half of the members

3. More than half of the members

4. Nearly all of the members

5. Doesn't apply/Don't know

\section{DECISION-MAKING, CONFLICT RESOLUTION}

Q10. Please circle the number below that shows how much influence you think the person or group has in deciding on the actions and policies for your coalition.

\begin{tabular}{|l|c|c|c|c|}
\hline & No Influence & $\begin{array}{c}\text { Some } \\
\text { Influence }\end{array}$ & $\begin{array}{c}\text { A Lot of } \\
\text { Influence }\end{array}$ & N/A \\
\hline Q10a) Coalition Chair & 1 & 2 & 3 & 4 \\
\hline Q10b) Officers or Committee Chairs & 1 & 2 & 3 & 4 \\
\hline Q10c) Lead Staff & 1 & 2 & 3 & 4 \\
\hline Q10d) Coalition Members & 1 & 2 & 3 & 4 \\
\hline
\end{tabular}

Q11. Please circle a number to show how much influence you personally have in making coalition decisions.
No Influence
Some Influence
A Lot of Influence
1 2
3

Q12. How are decisions usually made regarding coalition priorities, policies and actions?

Circle the number of the main way(s) you think decisions are usually made.

(CIRCLE NO MORE THAN TWO):

Q12.1. Coalition members vote, with majority rule

Q12.2. Coalition members discuss the issue and come to consensus

Q12.3. The coalition chair makes final decisions

Q12.4. The coalition executive or steering committee makes final decisions

Q12.5. The lead agency for the project makes the decisions 


\section{Q12.6. Don't know}

Q13. Please circle a number to show how comfortable you are overall with the coalition decision-making process.

\section{Not at All Comfortable Somewhat Comfortable Very Comfortable 1}


Q15. Please circle the main strategy your coalition has used to address conflicts that occur. (CIRLCE NO MORE THAN TWO):

Q15.1. Open dialogue about opposing viewpoints

Q15.2. Postponing or avoiding discussions of controversial issues

Q15.3. Having a third party mediate between those with opposing viewpoints

Q15.4. Having the opposing parties negotiate directly with each other

Q15.5. One party to the conflict gives in

Q15.6. Don't know

\section{LEADERSHIP, STAFFING, RELATIONSHIPS}

Q16. Who do you think is most significant in providing leadership for your coalition? (CIRCLE ONLY ONE NUMBER):

1. Coalition Chair

2. Coalition Officers or Committee Chairs

3. Lead Staff

4. Coalition Members

5. Other

6. Don't Know

Q17: The leadership of our coalition:

\begin{tabular}{|l|c|c|c|c|c|}
\hline & $\begin{array}{c}\text { Strongly } \\
\text { Disagree }\end{array}$ & Disagree & Agree & $\begin{array}{c}\text { Strongly } \\
\text { Agree }\end{array}$ & $\begin{array}{c}\text { Don't } \\
\text { Know }\end{array}$ \\
\hline Q17a) Has a clear vision for the coalition & 1 & 2 & 3 & 4 & 5 \\
\hline Q17b) Is respected in the community & 1 & 2 & 3 & 4 & 5 \\
\hline Q17c) Gets things done & 1 & 2 & 3 & 4 & 5 \\
\hline Q17d) Is respected in the coalition & 1 & 2 & 3 & 4 & 5 \\
\hline Q17e) Controls decisions & 1 & 2 & 3 & 4 & 5 \\
\hline Q17f) Intentionally seeks other's views & 1 & 2 & 3 & 4 & 5 \\
\hline $\begin{array}{l}\text { Q17g) Utilizes the skills and talents of } \\
\text { many, not just a few }\end{array}$ & 1 & 2 & 3 & 4 & 5 \\
\hline $\begin{array}{l}\text { Q17h) Creates an appropriate balance of } \\
\text { responsibility between leaders, staff and } \\
\text { members }\end{array}$ & 1 & 2 & 3 & 4 & 5 \\
\hline $\begin{array}{l}\text { Q17i) Advocates strongly for its own } \\
\text { opinions and agendas }\end{array}$ & 1 & 2 & 3 & 4 & 5 \\
\hline Q17j) Builds consensus on key decisions & 1 & 2 & 3 & 4 & 5 \\
\hline $\begin{array}{l}\text { Q17k) Works collaboratively with } \\
\text { coalition }\end{array}$ & 1 & 2 & 3 & 4 & 5 \\
\hline $\begin{array}{l}\text { Q17l) Keeps the coalition focused on } \\
\text { tasks and objectives }\end{array}$ & 1 & 2 & 3 & 4 & 5 \\
\hline Q17m) Is skillful in resolving conflict & 1 & 2 & 3 & 4 & 5 \\
\hline Q17n)Is ethical & 1 & 2 & 3 & 4 & 5 \\
\hline
\end{tabular}


Q18. Who actually sets the agenda for meetings of the coalition and its committee/task forces?

(PLEASE CIRCLE ALL THAT APPLY):

Q18.1. Coalition Chair

Q18.2. Coalition Officers or Committee Chairs

Q18.3. Lead Staff

Q18.4. Coalition Members

Q18.5. Don't know

Q19. Please circle a number to show how much you agree or disagree with each statement.

\begin{tabular}{|l|c|c|c|c|c|}
\hline & $\begin{array}{c}\text { Strongly } \\
\text { Disagree }\end{array}$ & Disagree & Agree & $\begin{array}{c}\text { Strongly } \\
\text { Agree }\end{array}$ & $\begin{array}{c}\text { Don't } \\
\text { Know }\end{array}$ \\
\hline Q19a) The coalition is well managed & 1 & 2 & 3 & 4 & 5 \\
\hline $\begin{array}{l}\text { Q19b) The work of the paid staff } \\
\text { supports the work of the coalition }\end{array}$ & 1 & 2 & 3 & 4 & 5 \\
\hline $\begin{array}{l}\text { Q19c) People know the roles of staff } \\
\text { a compared to coalition members }\end{array}$ & 1 & 2 & 3 & 4 & 5 \\
\hline $\begin{array}{l}\text { Q19d) Coalition members take } \\
\text { responsibility }\end{array}$ & 1 & 2 & 3 & 4 & 5 \\
\hline
\end{tabular}

\section{TRUST}

Q20. Please circle a number to show how much you agree or disagree with the following statements.

\begin{tabular}{|c|c|c|c|c|c|}
\hline & $\begin{array}{l}\text { Strongly } \\
\text { Disagree }\end{array}$ & Disagree & Agree & $\begin{array}{l}\text { Strongly } \\
\text { Agree }\end{array}$ & $\begin{array}{l}\text { Don't } \\
\text { Know }\end{array}$ \\
\hline $\begin{array}{l}\text { Q20a) Relationships among coalition } \\
\text { members go beyond individuals at the table, } \\
\text { to include member organizations }\end{array}$ & 1 & 2 & 3 & 4 & 5 \\
\hline $\begin{array}{l}\text { Q20b) I am comfortable requesting } \\
\text { assistance from the other coalition members } \\
\text { when I feel their input could be of value }\end{array}$ & 1 & 2 & 3 & 4 & 5 \\
\hline $\begin{array}{l}\text { Q20c) I can talk openly and honestly at the } \\
\text { coalition meeting }\end{array}$ & 1 & 2 & 3 & 4 & 5 \\
\hline $\begin{array}{l}\text { Q20d) I am comfortable expressing my point } \\
\text { of view even if they might disagree }\end{array}$ & 1 & 2 & 3 & 4 & 5 \\
\hline $\begin{array}{l}\text { Q20e) I am comfortable bringing up new } \\
\text { ideas at coalition meetings }\end{array}$ & 1 & 2 & 3 & 4 & 5 \\
\hline $\begin{array}{l}\text { Q20f) Coalition members respect each } \\
\text { others' points of view even if they might } \\
\text { disagree }\end{array}$ & 1 & 2 & 3 & 4 & 5 \\
\hline $\begin{array}{l}\text { Q20g) My opinion is listened to and } \\
\text { considered by other members }\end{array}$ & 1 & 2 & 3 & 4 & 5 \\
\hline
\end{tabular}

\section{Continue next page}




\section{MISSION STRATEGIES AND ACTION PLANS}

Q21. Please circle a number to show whether the following functions are major, minor, not a function, or you don't know.

The functions of our coalition are to:

\begin{tabular}{|l|c|c|c|c|}
\hline & $\begin{array}{c}\text { Not a } \\
\text { Function }\end{array}$ & $\begin{array}{c}\text { A Minor } \\
\text { Function }\end{array}$ & $\begin{array}{c}\text { A Major } \\
\text { Function }\end{array}$ & $\begin{array}{c}\text { Don't } \\
\text { Know }\end{array}$ \\
\hline Q21a) Network with other professionals & 1 & 2 & 3 & 4 \\
\hline Q21b) Network with concerned citizens & 1 & 2 & 3 & 4 \\
\hline Q21c) Conduct strategic planning & 1 & 2 & 3 & 4 \\
\hline $\begin{array}{l}\text { Q21d) Make decisions about priority needs and } \\
\text { problems }\end{array}$ & 1 & 2 & 3 & 4 \\
\hline $\begin{array}{l}\text { Q21e) Recommend or make decisions to allocate } \\
\text { resources }\end{array}$ & 1 & 2 & 3 & 4 \\
\hline Q21f) Operate particular programs or activities & 1 & 2 & 3 & 4 \\
\hline Q21g) Advocate for local public policy objectives & 1 & 2 & 3 & 4 \\
\hline Q21h) Advocate for state public policy objectives & 1 & 2 & 3 & 4 \\
\hline Q21i) Provide funding for current programs & 1 & 2 & 3 & 4 \\
\hline $\begin{array}{l}\text { Q21j) Raise funds to sustain long-term coalition } \\
\text { activities }\end{array}$ & 1 & 2 & 3 & 4 \\
\hline
\end{tabular}

Q22. Please circle a number to show how much you agree or disagree with the following statements.

\begin{tabular}{|l|c|c|c|c|c|}
\hline & $\begin{array}{l}\text { Strongly } \\
\text { Disagree }\end{array}$ & Disagree & Agree & $\begin{array}{l}\text { Strongly } \\
\text { Agree }\end{array}$ & $\begin{array}{l}\text { Don't } \\
\text { Know }\end{array}$ \\
\hline $\begin{array}{l}\text { Q22a) Our coalition has a clear and shared } \\
\text { understanding of the problems we are trying to } \\
\text { address }\end{array}$ & 1 & 2 & 3 & 4 & 5 \\
\hline $\begin{array}{l}\text { Q22b) There is a general agreement with respect } \\
\text { to the mission of the coalition }\end{array}$ & 1 & 2 & 3 & 4 & 5 \\
\hline $\begin{array}{l}\text { Q22c) There is general agreement with respect to } \\
\text { the priorities of the coalition }\end{array}$ & 1 & 2 & 3 & 4 & 5 \\
\hline $\begin{array}{l}\text { Q22d) Members agree on the strategies the } \\
\text { coalition should use in pursuing its priorities }\end{array}$ & 1 & 2 & 3 & 4 & 5 \\
\hline $\begin{array}{l}\text { Q22e) Our action plan defines well the roles, } \\
\text { responsibilities and timelines for conducting the } \\
\text { activities that work towards achieving the stated } \\
\text { mission of the coalition }\end{array}$ & 1 & 2 & 3 & 4 & 5 \\
\hline
\end{tabular}

Q23. Please circle a number to show how much you agree or disagree with the following statements.

\begin{tabular}{|l|c|c|c|c|c|}
\hline & $\begin{array}{c}\text { Strongly } \\
\text { Disagree }\end{array}$ & Disagree & Agree & $\begin{array}{c}\text { Strong } \\
\text { ly } \\
\text { Agree }\end{array}$ & $\begin{array}{c}\text { Don't } \\
\text { Know }\end{array}$ \\
\hline Q23a) Notification of meetings is timely & 1 & 2 & 3 & 4 & 5 \\
\hline $\begin{array}{l}\text { Q23b) Background materials needed for } \\
\text { meetings are prepared \& distributed in advance }\end{array}$ & 1 & 2 & 3 & 4 & 5 \\
\hline
\end{tabular}




\begin{tabular}{|l|l|l|l|l|l|}
\hline of meetings (agendas, minutes, study documents) & & & & & \\
\hline $\begin{array}{l}\text { Q23c) Informative committee and/or task force } \\
\text { reports are routinely made to the entire coalition }\end{array}$ & 1 & 2 & 3 & 4 & 5 \\
\hline
\end{tabular}

\section{PARTICIPATION}

Q24. Over the past year, how involved have you been in coalition activities?

1. Not at all involved

2. A little involved

3. Fairly involved

4. Very involved

Q25. Please circle a number to show how many times over the last year you personally have done the following for the coalition:

\begin{tabular}{|l|c|c|c|c|c|}
\hline & Never & $\begin{array}{l}\text { Rarely (1- } \\
\text { 2 times) }\end{array}$ & $\begin{array}{l}\text { Sometimes } \\
\text { (3-4 times) }\end{array}$ & $\begin{array}{l}\text { Often } \\
\text { (5+times) }\end{array}$ & N/A \\
\hline Q25a) Recruited new members & 1 & 2 & 3 & 4 & 5 \\
\hline Q25b) Served as a spokesperson & 1 & 2 & 3 & 4 & 5 \\
\hline $\begin{array}{l}\text { Q25c) Attempted to get outside support for } \\
\text { coalition positions on key issues }\end{array}$ & 1 & 2 & 3 & 4 & 5 \\
\hline $\begin{array}{l}\text { Q25d) Worked on implementing activities or } \\
\text { events sponsored by the coalition }\end{array}$ & 1 & 2 & 3 & 4 & 5 \\
\hline $\begin{array}{l}\text { Q25e) Acquired funding or other resources for } \\
\text { the coalition }\end{array}$ & 1 & 2 & 3 & 4 & 5 \\
\hline
\end{tabular}

Q26. Please circle a number to show how much you agree or disagree with the following statements:

\begin{tabular}{|l|c|c|c|c|c|}
\hline & $\begin{array}{l}\text { Strongly } \\
\text { Disagree }\end{array}$ & Disagree & Agree & $\begin{array}{l}\text { Strongly } \\
\text { Agree }\end{array}$ & $\begin{array}{c}\text { Don't } \\
\text { Know }\end{array}$ \\
\hline $\begin{array}{l}\text { Q26a) I feel that I have a voice in what the } \\
\text { coalition decides }\end{array}$ & 1 & 2 & 3 & 4 & 5 \\
\hline $\begin{array}{l}\text { Q26b) I go to coalition meetings only because it } \\
\text { is part of my job }\end{array}$ & 1 & 2 & 3 & 4 & 5 \\
\hline $\begin{array}{l}\text { Q26c) I am satisfied with how the coalition } \\
\text { operates }\end{array}$ & 1 & 2 & 3 & 4 & 5 \\
\hline $\begin{array}{l}\text { Q26d) I feel a strong sense of "loyalty" to the } \\
\text { coalition }\end{array}$ & 1 & 2 & 3 & 4 & 5 \\
\hline
\end{tabular}

Q27. Please circle a number to show how much you agree or disagree with the following statements. If you consider yourself an individual member (and circled \#1 in Q2), please do not answer this question and go to question Q28.

\begin{tabular}{|l|c|c|c|c|c|}
\hline & $\begin{array}{l}\text { Strongly } \\
\text { Disagree }\end{array}$ & Disagree & Agree & $\begin{array}{l}\text { Strongly } \\
\text { Agree }\end{array}$ & $\begin{array}{l}\text { Don't } \\
\text { Know }\end{array}$ \\
\hline $\begin{array}{l}\text { Q27a) Staff from my organization contribute } \\
\text { time to the coalition }\end{array}$ & 1 & 2 & 3 & 4 & 5 \\
\hline $\begin{array}{l}\text { Q27b) Volunteers from my organization } \\
\text { contribute time to the coalition }\end{array}$ & 1 & 2 & 3 & 4 & 5 \\
\hline
\end{tabular}




\begin{tabular}{|l|c|c|c|c|c|}
\hline $\begin{array}{l}\text { Q27c) My organization supports the positions } \\
\text { of the coalition publicly }\end{array}$ & 1 & 2 & 3 & 4 & 5 \\
\hline $\begin{array}{l}\text { Q27d) Overall, my organization is committed } \\
\text { to the work of the coalition }\end{array}$ & 1 & 2 & 3 & 4 & 5 \\
\hline $\begin{array}{l}\text { Q27e) My organization contributes funds to } \\
\text { support the coalition }\end{array}$ & 1 & 2 & 3 & 4 & 5 \\
\hline
\end{tabular}

Q28. Please circle a number to show to what extent each of the following has been a benefit to your participation or your organization's participation on the coalition.

\begin{tabular}{|l|c|c|c|c|c|}
\hline & $\begin{array}{c}\text { No } \\
\text { Benefit }\end{array}$ & $\begin{array}{c}\text { A Little } \\
\text { Benefit }\end{array}$ & $\begin{array}{c}\text { Some } \\
\text { Benefit }\end{array}$ & $\begin{array}{c}\text { Great } \\
\text { Benefit }\end{array}$ & N/A \\
\hline $\begin{array}{l}\text { Q28a) Developing collaborative relationships with } \\
\text { other agencies }\end{array}$ & 1 & 2 & 3 & 4 & 5 \\
\hline Q28b) Helping my organization move toward our goals & 1 & 2 & 3 & 4 & 5 \\
\hline $\begin{array}{l}\text { Q28c) Getting access to target populations with whom } \\
\text { we have previously had little contact }\end{array}$ & 1 & 2 & 3 & 4 & 5 \\
\hline Q28d) Getting funding for my organization & 1 & 2 & 3 & 4 & 5 \\
\hline Q28e) Getting services for our clients & 1 & 2 & 3 & 4 & 5 \\
\hline Q28f) Getting client referrals from others & 1 & 2 & 3 & 4 & 5 \\
\hline Q28g) Increasing my professional skills and knowledge & 1 & 2 & 3 & 4 & 5 \\
\hline $\begin{array}{l}\text { Q28h) Staying well informed in a rapidly changing } \\
\text { environment }\end{array}$ & 1 & 2 & 3 & 4 & 5 \\
\hline Q28i) Getting access to key policy makers & 1 & 2 & 3 & 4 & 5 \\
\hline $\begin{array}{l}\text { Q28j) Increasing my sense that others share my goals } \\
\text { and concerns }\end{array}$ & 1 & 2 & 3 & 4 & 5 \\
\hline $\begin{array}{l}\text { Q28k) Getting support for policy issues our } \\
\text { organization feels strongly about }\end{array}$ & 1 & 2 & 3 & 4 & 5 \\
\hline
\end{tabular}

Q29. Please circle a number to show to what extent each of the following have been problems for your participation or your organization's participation in the coalition.

\begin{tabular}{|l|c|c|c|c|}
\hline & Agree & $\begin{array}{c}\text { Disagree } \\
\text { Slightly }\end{array}$ & Disagree & $\begin{array}{c}\text { Don't } \\
\text { Know }\end{array}$ \\
\hline $\begin{array}{l}\text { Q29a) Coalition activities do not reach my primary } \\
\text { constituency }\end{array}$ & 1 & 2 & 3 & 4 \\
\hline $\begin{array}{l}\text { Q29b) My organization doesn't get enough public recognition } \\
\text { for our work on the coalition }\end{array}$ & 1 & 2 & 3 & 4 \\
\hline Q29c) Being involved in policy advocacy & 1 & 2 & 3 & 4 \\
\hline Q29d) My skills and time are not well-used & 1 & 2 & 3 & 4 \\
\hline Q29e) My (or my organization's) opinion is not valued & 1 & 2 & 3 & 4 \\
\hline Q29f) The coalition is not taking any meaningful action & 1 & 2 & 3 & 4 \\
\hline $\begin{array}{l}\text { Q29g) I am often the only voice representing my viewpoint } \\
\text { Q29h) The financial burden of traveling to coalition meetings } \\
\text { is too high }\end{array}$ & 1 & 2 & 3 & 4 \\
\hline $\begin{array}{l}\text { Q29i) The financial burden of participating in coalition } \\
\text { activities (barring travel) is too high }\end{array}$ & 1 & 2 & 3 & 4 \\
\hline
\end{tabular}


Q29j) The coalition is competing with my organization

2

Q30. From your organization's perspective (if applicable), do the benefits of participation in the coalition appear to outweigh the costs at this point?

1. No

2. Yes

3. I do not represent an organization on the coalition

Q31. From your own professional and/or personal perspective, do the benefits of participation in the coalition appear to outweigh the costs at this point?

1. No

2. Yes

3. Don't know

\section{COMMUNICATION}

Q32. Please circle a number to show how much you agree or disagree with the following statements.

\begin{tabular}{|l|c|c|c|c|c|}
\hline & $\begin{array}{c}\text { Strongly } \\
\text { Disagree }\end{array}$ & Disagree & Agree & $\begin{array}{c}\text { Strongly } \\
\text { Agree }\end{array}$ & $\begin{array}{c}\text { Don't } \\
\text { Know }\end{array}$ \\
\hline $\begin{array}{l}\text { Q32a) The current method for communication } \\
\text { between coalition staff/leadership and its } \\
\text { members is effective }\end{array}$ & 1 & 2 & 3 & 4 & 5 \\
\hline $\begin{array}{l}\text { Q32b) Members can communicate between } \\
\text { themselves as necessary or desired }\end{array}$ & 1 & 2 & 3 & 4 & 5 \\
\hline $\begin{array}{l}\text { Q32c) The coalition staff facilitates } \\
\text { communication between coalition members }\end{array}$ & 1 & 2 & 3 & 4 & 5 \\
\hline $\begin{array}{l}\text { Q32d) The coalition staff effectively and } \\
\text { efficiently notifies me of meetings, agenda } \\
\text { items, etc. }\end{array}$ & 1 & 2 & 3 & 4 & 5 \\
\hline $\begin{array}{l}\text { Q32e) The coalition utilizes effective strategies } \\
\text { to communicate with the broader public }\end{array}$ & 1 & 2 & 3 & 4 & 5 \\
\hline
\end{tabular}

\section{CHILDHOOD OBESITY KNOWLEDGE}

Q33. Do you feel you have adequate knowledge about childhood obesity to function effectively in the coalition?
1. No
2. Yes

Q34. Has the coalition helped you learn more about childhood obesity?

1. No

2. Yes 


\section{COALITION MATURITY, READINESS, SUSTAINABILITY}

Q35. Has your coalition been responsible for activities or programs that otherwise would not have occurred?
1. No
2. Yes
3. Don't know

Q36. Has your coalition brought benefit to your community?
1. No
2. Yes
3. Don't know

Q37. Please circle a number to show how much you agree or disagree with the following statements.

\begin{tabular}{|l|c|c|c|c|c|}
\hline & $\begin{array}{l}\text { Strongly } \\
\text { Disagree }\end{array}$ & Disagree & Agree & $\begin{array}{l}\text { Strongly } \\
\text { Agree }\end{array}$ & $\begin{array}{l}\text { Don't } \\
\text { Know }\end{array}$ \\
\hline $\begin{array}{l}\text { Q37a) The coalition is making progress in } \\
\text { implementing the activities that have potential to } \\
\text { improve childhood obesity. }\end{array}$ & 1 & 2 & 3 & 4 & 5 \\
\hline $\begin{array}{l}\text { Q37b) The coalition is improving health } \\
\text { outcomes for children who are at risk of obesity }\end{array}$ & 1 & 2 & 3 & 4 & 5 \\
\hline
\end{tabular}

Q38. Please circle a number to show how much you agree or disagree with the following statements.

\begin{tabular}{|l|c|c|c|c|c|}
\hline & $\begin{array}{l}\text { Strongly } \\
\text { Disagree }\end{array}$ & Disagree & Agree & $\begin{array}{l}\text { Strongly } \\
\text { Agree }\end{array}$ & $\begin{array}{l}\text { Don't } \\
\text { Know }\end{array}$ \\
\hline $\begin{array}{l}\text { Q38a) The coalition is making plans to } \\
\text { continue operating after current funding is } \\
\text { terminated }\end{array}$ & 1 & 2 & 3 & 4 & 5 \\
\hline $\begin{array}{l}\text { Q38b) The coalition has begun to find } \\
\text { resources to continue operating after current } \\
\text { funding is terminated }\end{array}$ & 1 & 2 & 3 & 4 & 5 \\
\hline $\begin{array}{l}\text { Q38c) Resources are being identified to } \\
\text { support the systemic, programmatic changes } \\
\text { implemented through the work of the coalition }\end{array}$ & 1 & 2 & 3 & 4 & 5 \\
\hline
\end{tabular}

Q39. Please circle a number to show how much you agree or disagree with the following statements.

\begin{tabular}{|l|c|c|c|c|c|}
\hline & $\begin{array}{l}\text { Strongly } \\
\text { Disagree }\end{array}$ & Disagree & Agree & $\begin{array}{l}\text { Strongly } \\
\text { Agree }\end{array}$ & $\begin{array}{l}\text { Don't } \\
\text { Know }\end{array}$ \\
\hline $\begin{array}{l}\text { Q39a) The coalition is essential to the } \\
\text { improvement of pediatric obesity }\end{array}$ & 1 & 2 & 3 & 4 & 5 \\
\hline $\begin{array}{l}\text { Q39b) One or a small number of people or } \\
\text { agencies could make significant progress in } \\
\text { pediatric obesity without the coalition }\end{array}$ & 1 & 2 & 3 & 4 & 5 \\
\hline $\begin{array}{l}\text { Q39c) In general I am satisfied with the } \\
\text { coalition }\end{array}$ & 1 & 2 & 3 & 4 & 5 \\
\hline
\end{tabular}


Q40. What issues should the coalition leadership and staff be paying more attention to?

Q41. Are there any critical events over the past year that have had an impact on the coalition? Please describe on the next page.

\section{Standard Section on Demographics of Respondents}

D1. Your gender:

1. Female

2. Male

D2. Your Race or Ethnicity:

D2.1. African American/Black

D2.2. White

D2.3. Asian American

D2.4. Native Hawaiian or other Pacific Islander

D2.5. Native American

D2.6. Latino or Hispanic

D2.6a: If Latino or Hispanic, do you consider yourself:

6.1. Puerto Rican/ "Newyorrican"

6.2. Mexican/Mexican American/Chicano

6.3. Cuban/Cuban American

6.4. Dominican

6.5. Other Spanish-Caribbean

6.6. Central American

6.7. South American

D2.6aOther: 6.8. Other Latino/Hispanic (please specify):

D2.7. Other Race or Ethnicity (please specify): 
D3. Your age at last birthday:

\section{_ YEARS}

D4. Your education:

1. Grade 8 or less

2. Graduated from high school

3. Graduated from technical or vocational school

4. Graduated from college

5. Completed graduate school

D5. Did you complete this survey when it was administered a year ago?

1. No

2. Yes

3. Don't Know 


\section{Appendix C - Self-Assessment Template for Coalition Feedback}

Coalition Self Assessment Summary Reporting Guide

\section{General Guidelines}

- This is only a summary of the answers, not an analysis, so make sure the language reflects this and make sure you don't draw attention to something by highlighting or bolding the font, for example

- Something to keep in mind when deciding whether or not to report responses as a percentage or as the \# of votes is confidentiality. If there are only a handful of members in the coalition and 1 person is reporting something negative, for example, it would be better to report as a percentage so that person doesn't feel singled out (see Q13 for an example)

- For questions with the strongly disagree-strongly agree choices, I lumped agree and strongly disagree together and disagree and strongly disagree together and reported percentages. For example in Q14..."100\% of members agree or strongly agree that the decision process is fair and that the coalition makes good decisions". It would not be necessary in this case to keep them separate and say " $90 \%$ strongly agree and $10 \%$ agree that..."

- Responses are reported in present tense

- For the questions in table format (see Q14b), if there happens to be a wide variety of answers, it may be important to actually copy the table and write in the number or $\%$ of responses. In the example below, some people saw personality clashes as causing "a lot" of conflict in the group, while others felt it caused none at all.

\begin{tabular}{lllll|l}
\hline & None & Some & $\begin{array}{l}\text { A } \\
\text { Lot }\end{array}$ & $\begin{array}{l}\text { Don't } \\
\text { Know }\end{array}$ & Average \\
\hline Differences in op inion ab out the mission and goals & 3 & 3 & 0 & 3 & 2.3 \\
\hline Differences in op inion ab out specific ob jectives & 4 & 3 & 0 & 2 & 2.0 \\
\hline Differences ab out best strategies to achieve goals & 3 & 4 & 0 & 0 & 2.1 \\
\hline Personality clashes & 5 & 1 & 1 & 0 & 2.0 \\
\hline Fighting for power, prestige and/or in fluence & 6 & 1 & 0 & 0 & 1.8 \\
\hline Fighting for resources & 5 & 1 & 1 & 0 & 2.0 \\
\hline Differences in op inion ab out who gets public exp osure and recognition & 6 & 1 & 0 & 0 & 1.8 \\
\hline Procedures for completing the work & 3 & 3 & 0 & 0 & 2.3 \\
\hline People aren't sufficiently included in coalition processes/decision making & 4 & 3 & 0 & 0 & 2.0 \\
\hline Members who dominate the meetings and impede collaboration & 5 & 2 & 0 & 0 & 1.9 \\
\hline
\end{tabular}

The following document is a copy of the entire Coalition Self Assessment Survey with comments next to each question on how to report them in the summary. 


\section{ROLE IN COALITION}

Q1. What is your role in the coalition? Circle more than one response, if appropriate.

Comment [JD1]: Report the \% for each
a. Member of the steering or executive committee
b. Coalition chair or officer
c. Chair/co-chair of a coalition committee or task force
d. Committee member
e. Member (no other responsibility)
f. Staff
g. Other

Q2. Are you part of the coalition as an individual member or as a representative of an organization? Please circle either 1 or 2 , or both, if appropriate.

1. Individual Member, not representing an organization

2. Representative of an organization

3. Both

Q2a. If you are an individual member not representing an organization, please specify your role (for example, "parent")

Q2b. If you are an individual member not representing an organization, how long have you been an individual member of the coalition?

YEARS

MONTHS

DON'T KNOW

NOT APPLICABLE

Q3. If you represent an organization, please indicate the one that best describes the Organization you represent in this coalition. Please circle only one.

1. Community Health Center/Community clinic

2. Community/neighborhood group

3. Ethnic and minority group organization

4. Youth organization

5. Parent organization

6. Women's organization

7. Religious/Faith-based organization

8 . Housing organization

9. Environmental advocacy group

10. Environmental agency

11. Voluntary agency that has obesity as a key part of their mission

12. Other voluntary agency

13. Other community-based organization

14. Other coalition

15. After school program/Parks and recreation

16. Day care/Preschool/Head Start center

17. School (any grades K-12)

18. Academic institution (college/university)

19. HMO and other managed care organization

20. Medicaid and other insurers

21. Pharmaceutical company

22. Hospital

see next page for continuation 
23. Health care provider organization (non-hospital)

24. Physician practice

25. Local health department

26. State health department

27. Business

28. Media

29. Legislative office

30. Other (please specify)

Q4. If a representative of an organization, how long has your organization been represented in the coalition?

YEARS _ MONTHS DON'T KNOW NOT APPLICABLE

Q5. Please circle the role that fits you best. Circle only one.

Comment [JD4]: Report roles. E.G. "Members Health Educator ( $\mathrm{n}=1$ ), etc."

1. Physician, please specify

2. Physician assistant

3. Nurse/nurse practitioner

4. Respiratory therapist

5. Social worker/case worker

6. Case manager

7. Community health worker

8. Outreach worker

9. Health educator

10. Other health professional, please specify

11. Day care/Head Start provider

12. After school/parks and recreation provide

13. Government official/staff

14. Parent/caregiver

15. Staff from non-profit

16. Administrator

17. Researcher/evaluator

18. Other, please specify

\section{INCLUSION, RECRUITMENT, MEMBERSHIP}

Q6. In your opinion, does your coalition have sufficient representation from groups organizations, and/or schools in your community to accomplish the objectives of the coalition?

1. No

2. Yes

3. Don't Know

Q6a. If you answered "no" above, in your opinion, which type of the following groups, organizations and/or schools listed are NOT well represented on the coalition? Circle all that apply.

1. Community Health Center/Community clinic

2. Community/neighborhood council or advisory group

3. Ethnic and minority group organization

4. Youth organization

5. Parent organization 
6. Women's organization

7. Religious/Faith-based organization

8. Housing organization

9. Environmental advocacy group

10. Environmental agency

11. Voluntary agency that has childhood obesity as a key part of their mission

12. Other voluntary agency

13. Other community-based organization

14. Other coalition

15. After school program/Parks and recreation

16. Day care/Preschool/Head Start center

17. School K-12

18. Academic institution (college/university)

19. HMO and other managed care organization

20. Medicaid and other insurers

21. Pharmaceutical company

22. Hospital

23. Health care provider organization (non-hospital)

24. Physician practice

25. Local health department

26. State health department

27. Business

28. Media

29. Legislative office

30. Parents/caregivers of 4-year old children

31. Other (please specify)

32. None of the above

Q6b. If you have circled one or more groups above as being not well represented, please select the SINGLE group you think is most important to add to the coalition at this time. Write the number of the group on this line

Q6c. Why do you think the group identified as most important to add to the coalition is not well represented at this time? (CIRCLE ALL THAT/APPLY):

1. The coalition never tried to involve them

2. The coalition invited them but they chose not to participate

3. They used to participate but dropped out

4. The coalition cannot get access to representatives of this group

5. The coalition as a whole is not sure that this group should be asked to join

6. Resources are lacking to recruit new members

7. Some coalition members do not want to share power with this group

8. Don't know

Q7. Is your coalition actively recruiting new members?

1. No

2. Yes

3. Don't know 
Q8. In your opinion, do new members receive adequate orientation to be effective members of the coalition?

1. No

2. Yes

3. Don't know

Q9. Of those that represent organizations, please circle the number which best represents your opinion about the number of members who participate in your coalition who have enough authority to make commitments of resources or other support for the coalition.

1. Less than one-quarter of the members

2. Less than half of the members

3. More than half of the members

4. Nearly all of the members

5. Doesn't apply/Don't know

\section{DECISION-MAKING, CONFLICT RESOLUTION}

Q10. Please circle the number below that shows how much influence you think the person or group has in deciding on the actions and policies for your coalition.

\begin{tabular}{|l|c|c|c|c|}
\hline & No Influence & $\begin{array}{c}\text { Some } \\
\text { Influence }\end{array}$ & $\begin{array}{c}\text { A Lot of } \\
\text { Influence }\end{array}$ & N/A \\
\hline a) Coalition Chair & 1 & 2 & 3 & 4 \\
\hline b) Officers or Committee Chairs & 1 & 2 & 3 & 4 \\
\hline c) Lead Staff & 1 & 2 & 3 & 4 \\
\hline d) Coalition Members & 1 & 2 & 3 & 4 \\
\hline
\end{tabular}

Comment [JD11]: In our coalitions, most said that all of the se people/groups had a "lot of influence" so I reported that $\%$

E.C. decisions" -

Q11. Please circle a number to show how much influence you personally have in making coalition decisions.

No Influence Some Influence A Lot of Influence
2

\section{3}

Q12. How are decisions usually made regarding coalition priorities, policies and actions? Circle the number of the main way(s) you think decisions are usually made. (CIRCLE NO MORE THAN TWO):

1. Coalition members vote, with majority rule

2. Coalition members discuss the issue and come to consensus

3. The coalition chair makes final decisions

4. The coalition executive or steering committee makes final decisions

5. The lead agency for the project makes the decisions

6. Don't know

Q13. Please circle a number to show how comfortable you are overall with the coalition decision-making process

Not at All Comfortable

Somewhat Comfortable 2

(2)

Very Comfortable 3

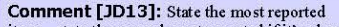
item...state the second most reported if it's slos 
Q14. Please circle a number to show how much you agree or disagree with the following statements.

\begin{tabular}{|l|c|c|c|c|c|}
\hline & $\begin{array}{l}\text { Strongly } \\
\text { Disagree }\end{array}$ & Disagree & Agree & $\begin{array}{c}\text { Strongly } \\
\text { Agree }\end{array}$ & $\begin{array}{c}\text { Don't } \\
\text { Know }\end{array}$ \\
\hline $\begin{array}{l}\text { a) The coalition has clear and explicit } \\
\text { procedures for making important decisions }\end{array}$ & 1 & 2 & 3 & 4 & 5 \\
\hline $\begin{array}{l}\text { b) The coalition follows standard procedures } \\
\text { for making decisions }\end{array}$ & 1 & 2 & 3 & 4 & 5 \\
\hline $\begin{array}{l}\text { c) The decision making process used by the } \\
\text { coalition is fair }\end{array}$ & 1 & 2 & 3 & 4 & 5 \\
\hline $\begin{array}{l}\text { d) The decision-making process used by the } \\
\text { coalition is timely }\end{array}$ & 1 & 2 & 3 & 4 & 5 \\
\hline e) The coalition makes good decisions & 1 & 2 & 3 & 4 & 5 \\
\hline
\end{tabular}

Comment [JD15]: For the following qucstions with this kind of format, Ilumped the agree and strongly agree together and the disagree and strongly di sagree together and reported them as percentages...see below

Comment [JD16]: E.G. " $100 \%$ of members agree or strongly agree that the decision process is fair and that the coalition makes good decisions. $29 \%$ of members disagree that there are clear and explicit procedures for making important decisions, and that the decisions are timely and follow standar procedure

Q14a. Circle the number that represents the amount of conflict in your coalition

1. More conflict than I expected

2. Less conflict than I expected

3. About as much conflict as I expected

Q14b. Circle the number that best represents your opinion of how much conflict within the coalition was caused by each of the following factors:

\begin{tabular}{|l|c|c|c|c|}
\hline & None & Some & A Lot & $\begin{array}{c}\text { Don't } \\
\text { Know }\end{array}$ \\
\hline $\begin{array}{l}\text { a) Differences in opinion about coalition mission and goals } \\
\text { coalition goals and objectives }\end{array}$ & 1 & 2 & 3 & 4 \\
\hline b) Differences in opinion about specific objectives & 1 & 2 & 3 & 4 \\
\hline c) Differences in opinion about the best strategies to achieve & 1 & 2 & 3 & 4 \\
\hline d) Personality clashes & 1 & 2 & 3 & 4 \\
\hline e) Fighting for power, prestige and/or influence & 1 & 2 & 3 & 4 \\
\hline f) Fighting for resources & 1 & 2 & 3 & 4 \\
\hline $\begin{array}{l}\text { g) Differences in opinion about who gets public exposure and } \\
\text { recognition }\end{array}$ & 1 & 2 & 3 & 4 \\
\hline h) Procedures used for completing the work & 1 & 2 & 3 & 4 \\
\hline $\begin{array}{l}\text { i) People aren't sufficiently included in coalition } \\
\text { processes/decision making }\end{array}$ & 1 & 2 & 3 & 4 \\
\hline $\begin{array}{l}\text { j) Member(s) who dominate the coalition meetings and } \\
\text { impede proper collaboration }\end{array}$ & 1 & 2 & 3 & 4 \\
\hline
\end{tabular}

Q15. Please circle the main strategy your coalition has used to address conflicts that occur. (CIRLCE NO MORE THAN (TWO):

Comment [JD18]: See example in my summary...For this one I copied the table and filled in the number of votes and the average. I thought it was important for them to see votes for all items rather than an average or $\%$ because the responses varied so much

1. Open dialogue_about opposing viewpoints

2. Postponing or avoiding discussions of controversial issues

3. Having a third party mediate between those with opposing viewpoints

4. Having the opposing parties negotiate directly with each other

5. One party to the conflict gives in

6. Don't know 


\section{LEADERSHIP, STAFFING, RELATIONSHIPS}

Q16. Who do you think is most significant in providing leadership for your coalition? (CIRCLE ONLY ONE NUMBER):

1. Coalition Chair

2. Coalition Officers or Committee Chairs

3. Lead Staff

4. Coalition Members

5. Other

6. Don't Know

Q17: The leadership of our coalition:

\begin{tabular}{|l|c|c|c|c|c|}
\hline & $\begin{array}{c}\text { Strongly } \\
\text { Disagree }\end{array}$ & Disagree & Agree & $\begin{array}{c}\text { Strongly } \\
\text { Agree }\end{array}$ & $\begin{array}{c}\text { Don't } \\
\text { Know }\end{array}$ \\
\hline a) Has a clear vision for the coalition & 1 & 2 & 3 & 4 & 5 \\
\hline b) Is respected in the community & 1 & 2 & 3 & 4 & 5 \\
\hline c) Gets things done & 1 & 2 & 3 & 4 & 5 \\
\hline d) Is respected in the coalition & 1 & 2 & 3 & 4 & 5 \\
\hline e) Controls decisions & 1 & 2 & 3 & 4 & 5 \\
\hline f) Intentionally seeks other's views & 1 & 2 & 3 & 4 & 5 \\
\hline $\begin{array}{l}\text { g) Utilizes the skills and talents of } \\
\text { many, not just a few }\end{array}$ & 1 & 2 & 3 & 4 & 5 \\
\hline $\begin{array}{l}\text { h) Creates an appropriate balance of } \\
\text { responsibility between leaders, staff } \\
\text { and members }\end{array}$ & 1 & 2 & 3 & 4 & 5 \\
\hline $\begin{array}{l}\text { i) Advocates strongly for its own } \\
\text { opinions and agendas }\end{array}$ & 1 & 2 & 3 & 4 & 5 \\
\hline j) Builds consensus on key decisions & 1 & 2 & 3 & 4 & 5 \\
\hline k) Works collaboratively with coalition & 1 & 2 & 3 & 4 & 5 \\
\hline $\begin{array}{l}\text { 1) Keeps the coalition focused on tasks } \\
\text { and objectives }\end{array}$ & 1 & 2 & 3 & 4 & 5 \\
\hline m) Is skillful in resolving conflict & 1 & 2 & 3 & 4 & 5 \\
\hline n) Is ethical & 1 & 2 & 3 & 4 & 5 \\
\hline
\end{tabular}

Comment [JD21]: For our coalitions, there was really no differences in responses so I just stated "All members agrec or strongly agrec that hicir lcader coalition, gets things done, seeks others' views, builds consensus, is ethical, keeps group focused on goals, works collaboratively, and utilizes the skills of many"

However, if the responses are varied and you feel it is important to point out the differences, you can copy the table (ilke in Q14b) or state \% or \# for each item where there is no consensus. Just keep er they are reporting on

Q18. Who actually sets the agenda for meetings of the coalition and its committee/task forces? (PLEASE CIRCLE ALL THAT APPLY):

1. Coalition Chair

2. Coalition Officers or Committee Chairs

3. Lead Staff

4. Coalition Members

5. Don't know 
8

Q19. Please circle a number to show how much you agree or disagree with each statement. Comment [JD23]: E.G. "Mcmbers agrec or strongly agree that the coalition is well managed and that members take responsibility. 1 member

\begin{tabular}{|l|c|c|c|c|c|}
\hline & $\begin{array}{c}\text { Strongly } \\
\text { Disagree }\end{array}$ & Disagree & Agree & $\begin{array}{c}\text { Strongly } \\
\text { Agree }\end{array}$ & $\begin{array}{c}\text { Don't } \\
\text { Know }\end{array}$ \\
\hline a) The coalition is well managed & 1 & 2 & 3 & 4 & 5 \\
\hline $\begin{array}{l}\text { b) The work of the paid staff } \\
\text { supports the work of the coalition }\end{array}$ & 1 & 2 & 3 & 4 & 5 \\
\hline $\begin{array}{l}\text { c) People know the roles of staff as } \\
\text { compared to ccalition members }\end{array}$ & 1 & 2 & 3 & 4 & 5 \\
\hline $\begin{array}{l}\text { d) Coalition members take } \\
\text { responsibility }\end{array}$ & 1 & 2 & 3 & 4 & 5 \\
\hline
\end{tabular}

\section{TRUST}

Q20. Please circle a number to show how much you agree or disagree with the following statements.

\begin{tabular}{|l|c|c|c|c|c|}
\hline & $\begin{array}{c}\text { Strongly } \\
\text { Disagree }\end{array}$ & Disagree & Agree & $\begin{array}{c}\text { Strongly } \\
\text { Agree }\end{array}$ & $\begin{array}{c}\text { Don't } \\
\text { Know }\end{array}$ \\
\hline $\begin{array}{l}\text { a) Relationships among coalition members } \\
\text { go beyond individuals at the table, to include } \\
\text { member organizations }\end{array}$ & 1 & 2 & 3 & 4 & 5 \\
\hline $\begin{array}{l}\text { b) I am comfortable requesting assistance } \\
\text { from the other coalition members when I feel } \\
\text { their input could be of value }\end{array}$ & 1 & 2 & 3 & 4 & 5 \\
\hline $\begin{array}{l}\text { c) I can talk openly and honestly at the } \\
\text { coalition meeting }\end{array}$ & 1 & 2 & 3 & 4 & 5 \\
\hline $\begin{array}{l}\text { d) I am comfortable expressing my point of } \\
\text { view even if they might disagree }\end{array}$ & 1 & 2 & 3 & 4 & 5 \\
\hline $\begin{array}{l}\text { e) I am comfortable bringing up new ideas at } \\
\text { coalition meetings }\end{array}$ & 1 & 2 & 3 & 4 & 5 \\
\hline $\begin{array}{l}\text { f) Coalition members respect each others' } \\
\text { points of view even if they might disagree }\end{array}$ & 1 & 2 & 3 & 4 & 5 \\
\hline $\begin{array}{l}\text { g) My opinion is listened to and considered } \\
\text { by other members }\end{array}$ & 1 & 2 & 3 & 4 & 5 \\
\hline
\end{tabular}

Comment [JD24]: Again, if there is a lot of agreement in responses, you can state the following...E.G. "All members agree or strongly agree that, they can talk openly and honestly, are comfortable expressing point of view and new ideas, opinion is listened to and considered by others".

However, if the responses are varied and you feel it is important to point out the differences, you can copy the table (like in Q14b) or state \% or \# for each item where there is no consensus

\section{Continue next page}




\section{MISSION STRATEGIES AND ACTION PLANS}

Q21. Please circle a number to show whether the following functions are major, minor, not a function, or you don't know.

The functions of our coalition are tod:
\begin{tabular}{|l|c|c|c|c|}
\hline & $\begin{array}{c}\text { Not a } \\
\text { Function }\end{array}$ & $\begin{array}{c}\text { A Minor } \\
\text { Function }\end{array}$ & $\begin{array}{c}\text { A Major } \\
\text { Function }\end{array}$ & $\begin{array}{c}\text { Don't } \\
\text { Know }\end{array}$ \\
\hline a) Network with other professionals & 1 & 2 & 3 & 4 \\
\hline b) Network with concerned citizens & 1 & 2 & 3 & 4 \\
\hline c) Conduct strategic planning & 1 & 2 & 3 & 4 \\
\hline d) Make decisions about priority needs and problems & 1 & 2 & 3 & 4 \\
\hline $\begin{array}{l}\text { e) Recommend or make decisions to allocate } \\
\text { resources }\end{array}$ & 1 & 2 & 3 & 4 \\
\hline f) Operate particular programs or activities & 1 & 2 & 3 & 4 \\
\hline g) Advocate for local public policy objectives & 1 & 2 & 3 & 4 \\
\hline h) Advocate for state public policy objectives & 1 & 2 & 3 & 4 \\
\hline i) Provide funding for current programs & 1 & 2 & 3 & 4 \\
\hline j) Raise funds to sustainlong-term coalition activities & 1 & 2 & 3 & 4 \\
\hline
\end{tabular}

Comment [JD25]: I used the whole table here like in Q14b because the responses were so varied and it was important for them to see that people didn't agree on the function of their coalition.

However, if there is consensus in your coalitions, you can report the same as you did for previous

Q22. Please circle a number to show how much you agree or disagree with the following statements

\begin{tabular}{|l|c|c|c|c|c|}
\hline & $\begin{array}{l}\text { Strongly } \\
\text { Disagree }\end{array}$ & Disagree & Agree & $\begin{array}{l}\text { Strongly } \\
\text { Agree }\end{array}$ & $\begin{array}{l}\text { Don't } \\
\text { Know }\end{array}$ \\
\hline $\begin{array}{l}\text { a) Our coalition has a clear and shared } \\
\text { understanding of the problems we are trying to } \\
\text { address }\end{array}$ & 1 & 2 & 3 & 4 & 5 \\
\hline $\begin{array}{l}\text { b) There is a general agreement with respect to } \\
\text { the mission of the coalition }\end{array}$ & 1 & 2 & 3 & 4 & 5 \\
\hline $\begin{array}{l}\text { c) There is general agreement with respect to the } \\
\text { priorities of the coalition }\end{array}$ & 1 & 2 & 3 & 4 & 5 \\
\hline $\begin{array}{l}\text { d) Members agree on the strategies the coalition } \\
\text { should use in pursuing its priorities }\end{array}$ & 1 & 2 & 3 & 4 & 5 \\
\hline $\begin{array}{l}\text { e) Our action plan defines well the roles, } \\
\text { responsibilities and timelines for conducting the } \\
\text { activities that work towards achieving the stated } \\
\text { mission of the coalition }\end{array}$ & 1 & 2 & 3 & 4 & 5 \\
\hline
\end{tabular}

Comment [JD26]: Same as above...if no consensus in responses, then copy the table.

If there is consensus, you can state something like ais.. $85 \%$ of members agree or strongly agree that being addressed, that there is agreement on the mission, priorities, and strategies used. 1 memb strongly disagrees that the action plan defines the roles and responsibilities of members"

Q23. Please circle a number to show how much you agree or disagree with the following statements.

\begin{tabular}{|l|c|c|c|c|c|}
\hline & $\begin{array}{c}\text { Strongly } \\
\text { Disagree }\end{array}$ & Disagree & Agree & $\begin{array}{c}\text { Strong } \\
\text { ly } \\
\text { Agree }\end{array}$ & $\begin{array}{c}\text { Don't } \\
\text { Know }\end{array}$ \\
\hline a) Notification of meetings is timely & 1 & 2 & 3 & 4 & 5 \\
\hline $\begin{array}{l}\text { b) Background materials needed for meetings are } \\
\text { prepared \& distributed in advance of meetings } \\
\text { (agendas, minutes, study documents) }\end{array}$ & 1 & 2 & 3 & 4 & 5 \\
\hline $\begin{array}{l}\text { c) Informative committee and/or task force } \\
\text { reports are routinely made to the entire coalition }\end{array}$ & 1 & 2 & 3 & 4 & 5 \\
\hline
\end{tabular}




\section{PARTICIPATION}

Q24. Over the past year, how involved have you been in coalition lactivitiest?

1. Not at all involved

2. A little involved

3. Fairly involved

4. Very involved

Comment [JD28]: Report \# or \% for each. E.G $50 \%$ of members believe they were "a little involved", $30 \%$ "fairly involved", and $10 \%$ "very involved".

Q25. Please circle a number to show how many times over the last year you per sonally have done the following for the coalition:

\begin{tabular}{|l|c|c|c|c|c|}
\hline & Never & $\begin{array}{l}\text { Rarely } \\
\mathbf{( 1 - 2} \\
\text { times })\end{array}$ & $\begin{array}{l}\text { Sometimes } \\
\mathbf{( 3 - 4} \text { times) }\end{array}$ & $\begin{array}{l}\text { Often } \\
\text { (5+times) }\end{array}$ & N/A \\
\hline a) Recruited new members & 1 & 2 & 3 & 4 & 5 \\
\hline b) Served as a spokesperson & 1 & 2 & 3 & 4 & 5 \\
\hline $\begin{array}{l}\text { c) Attempted to get outside support for } \\
\text { coalition positions on key issues }\end{array}$ & 1 & 2 & 3 & 4 & 5 \\
\hline $\begin{array}{l}\text { d) Worked on implementing activities or events } \\
\text { sponsored by the coalition }\end{array}$ & 1 & 2 & 3 & 4 & 5 \\
\hline $\begin{array}{l}\text { e) Acquired funding or other resources for the } \\
\text { coalition }\end{array}$ & 1 & 2 & 3 & 4 & 5 \\
\hline
\end{tabular}

Q26. Please circle a number to show how much you agree or disagree with the following statements:

\begin{tabular}{|l|c|c|c|c|c|}
\hline & $\begin{array}{l}\text { Strongly } \\
\text { Disagree }\end{array}$ & Disagree & Agree & $\begin{array}{l}\text { Strongly } \\
\text { Agree }\end{array}$ & $\begin{array}{l}\text { Don't } \\
\text { Know }\end{array}$ \\
\hline $\begin{array}{l}\text { a) I feel that I have a voice in what the } \\
\text { coalition decides }\end{array}$ & 1 & 2 & 3 & 4 & 5 \\
\hline $\begin{array}{l}\text { b) I go to coalition meetings only because it } \\
\text { is part of my job }\end{array}$ & 1 & 2 & 3 & 4 & 5 \\
\hline $\begin{array}{l}\text { c) I am satisfied with how the coalition } \\
\text { operates }\end{array}$ & 1 & 2 & 3 & 4 & 5 \\
\hline $\begin{array}{l}\text { d) I feel a strong sense of "loyalty" to the } \\
\text { coalition }\end{array}$ & 1 & 2 & 3 & 4 & 5 \\
\hline
\end{tabular}

Comment [JD29]: E.G. "All members agree or strongly agree that they have a voice in what the coalition decides, that they feel loyalty to the group,
and that they are satisfied with how coalition operates"

Q27. Please circle a number to show how much you agree or disagree with the following statements. If you consider yourself an individual member (and circled \#1 in Q2), please do not answer this question and go to question Q28.

\begin{tabular}{|l|c|c|c|c|c|}
\hline & $\begin{array}{l}\text { Strongly } \\
\text { Disagree }\end{array}$ & Disagree & Agree & $\begin{array}{l}\text { Strongly } \\
\text { Agree }\end{array}$ & $\begin{array}{l}\text { Don't } \\
\text { Know }\end{array}$ \\
\hline $\begin{array}{l}\text { a) Staff from my organization contribute time } \\
\text { to the coalition }\end{array}$ & 1 & 2 & 3 & 4 & 5 \\
\hline $\begin{array}{l}\text { b) Volunteers from my organization } \\
\text { contribute time to the ccalition }\end{array}$ & 1 & 2 & 3 & 4 & 5 \\
\hline $\begin{array}{l}\text { c) My organization supports the positions of } \\
\text { the coalition publicly }\end{array}$ & 1 & 2 & 3 & 4 & 5 \\
\hline $\begin{array}{l}\text { d) Overall, my organization is committed to } \\
\text { the work of the coalition }\end{array}$ & 1 & 2 & 3 & 4 & 5 \\
\hline $\begin{array}{l}\text { e) My organization contributes funds to } \\
\text { support the coalition }\end{array}$ & 1 & 2 & 3 & 4 & 5 \\
\hline
\end{tabular}

Comment [JD30]: I did not report this item because most people were individual members and thus skipped it 
Q28. Please circle a number to show to what extent each of the following has been a benefit to your participation or your organization's participation on the coalition.

\begin{tabular}{|l|c|c|c|c|c|}
\hline & $\begin{array}{c}\text { No } \\
\text { Benefit }\end{array}$ & $\begin{array}{c}\text { A Little } \\
\text { Benefit }\end{array}$ & $\begin{array}{c}\text { Some } \\
\text { Benefit }\end{array}$ & $\begin{array}{c}\text { Great } \\
\text { Benefit }\end{array}$ & N/A \\
\hline $\begin{array}{l}\text { a) Developing collaborative relationships with } \\
\text { other agencies }\end{array}$ & 1 & 2 & 3 & 4 & 5 \\
\hline $\begin{array}{l}\text { b) Helping my organization move toward our } \\
\text { goals }\end{array}$ & 1 & 2 & 3 & 4 & 5 \\
\hline $\begin{array}{l}\text { c) Getting access to target populations with } \\
\text { whom we have previously hadlittle contact }\end{array}$ & 1 & 2 & 3 & 4 & 5 \\
\hline d) Getting funding for my organization & 1 & 2 & 3 & 4 & 5 \\
\hline e) Getting services for our clients & 1 & 2 & 3 & 4 & 5 \\
\hline f) Getting client referrals from others & 1 & 2 & 3 & 4 & 5 \\
\hline $\begin{array}{l}\text { g) Increasing my professional skills and } \\
\text { knowledge }\end{array}$ & 1 & 2 & 3 & 4 & 5 \\
\hline $\begin{array}{l}\text { h) Staying well informed in a rapidly changing } \\
\text { environment }\end{array}$ & 1 & 2 & 3 & 4 & 5 \\
\hline $\begin{array}{l}\text { i) Getting access to key policy makers } \\
\text { j) Increasing my sense that others share my } \\
\text { goals and concerns } \\
\text { k) Getting support for policy issues our } \\
\text { organization feels strongly about }\end{array}$ & 1 & 2 & 3 & 4 & 5 \\
\hline
\end{tabular}

Comment [JD31]: For one of our coalitions there vas a lot of variety in responses that I felt was important to show so I copied the whole table (sec example

For our other coalition the responses were similar so I reported it like this..." The following are reported as having a "great benefit" to their particip ation.. 1) developing collabor ative relationships with other agcncies, 2) helping their org move towards goal s, 3 ) increase professional skills and knowledge, and 4)

organization feels strongly about

Q29. Please circle a number to show to what extent each of the following have been problems for your participation or your organization's participation in the coalition

\begin{tabular}{|l|c|c|c|c|}
\hline & Agree & $\begin{array}{c}\text { Disagree } \\
\text { Slightly }\end{array}$ & Disagree & $\begin{array}{c}\text { Don't } \\
\text { Know }\end{array}$ \\
\hline a) Coalition activities do not reach my primary constituency & 1 & 2 & 3 & 4 \\
\hline $\begin{array}{l}\text { b) My organization doesn't get enough public recognition } \\
\text { for our work on the coalition }\end{array}$ & 1 & 2 & 3 & 4 \\
\hline c) Being involved in policy advocacy & 1 & 2 & 3 & 4 \\
\hline d) My skills and time are not well-used & 1 & 2 & 3 & 4 \\
\hline e) My (or my organization's) opinion is not valued & 1 & 2 & 3 & 4 \\
\hline f) The coalition is not taking any meaningful action & 1 & 2 & 3 & 4 \\
\hline g) I am often the only voice representing my viewpoint & 1 & 2 & 3 & 4 \\
\hline $\begin{array}{l}\text { h) The financial burden of traveling to coalition meetings is } \\
\text { too high }\end{array}$ & 1 & 2 & 3 & 4 \\
\hline $\begin{array}{l}\text { 1) The financial burden of participating in coalition } \\
\text { activities (barring travel) is too high }\end{array}$ & 1 & 2 & 3 & 4 \\
\hline j) The coalition is competing with my organization & 1 & 2 & 3 & 4 \\
\hline
\end{tabular}

Comment [JD32]: I wouldn't copy the table for this question just in ease it effects confidentiality since they are reporting something negative. I jus stated overall what some of the problems wer without giving numbers or per centages.

E.G. "Members report the following problems due to coalition, skills are not well-used, my or my org's opinion is not valued, the coalition is competing with my org, and I am often the only voice representing my vicwpoint"

Q30. From your organization's perspective (if applicable), do the benefits of participation in the coalition appear to outweigh the costs at this point? 1. No

2. Yes

3. I do not represent an organization on the coalition

Comment []D33]: Most did not answer this question as it was $\mathrm{n} / \mathrm{a}$ 
Q31. From your own professional and/or personal perspective, do the benefits of participation in the coalition appear to outweigh the costs at this point?

1. No

2. Yes

3. Don't know

\section{COMMUNICATION}

Q32. Please circle a number to show how much you agree or disagree with the following statements

\begin{tabular}{|l|c|c|c|c|c|}
\hline & $\begin{array}{c}\text { Strongly } \\
\text { Disagree }\end{array}$ & Disagree & Agree & $\begin{array}{c}\text { Strongly } \\
\text { Agree }\end{array}$ & $\begin{array}{c}\text { Don't } \\
\text { Know }\end{array}$ \\
\hline $\begin{array}{l}\text { a) The current method for communication } \\
\text { between coalition staffleadership and its } \\
\text { members is effective }\end{array}$ & 1 & 2 & 3 & 4 & 5 \\
\hline $\begin{array}{l}\text { b) Members can communicate between } \\
\text { themselves as necessary or desired }\end{array}$ & 1 & 2 & 3 & 4 & 5 \\
\hline $\begin{array}{l}\text { c) The coalition staff facilitates communication } \\
\text { between coalition members }\end{array}$ & 1 & 2 & 3 & 4 & 5 \\
\hline $\begin{array}{l}\text { d) The coalition staff effectively and efficiently } \\
\text { notifies me of meetings, agenda items, etc. }\end{array}$ & 1 & 2 & 3 & 4 & 5 \\
\hline $\begin{array}{l}\text { 3) The coalition utilizes effective strategies to } \\
\text { communicate with the broader public }\end{array}$ & 1 & 2 & 3 & 4 & 5 \\
\hline
\end{tabular}

Comment [JD34]: State the \% that agree or strongly agree. E. G. " $100 \%$ of members agree or to communi cate with broader public, that members can communicate among themselves, that they are efficiently noti fied of meetings, that staff facilitate communication between members, and that the current method of communication is effective

\section{CHILDHOOD OBESITY KNOWLEDGE}

Q33. Do you feel you have adequate knowledge about childhood obesity to fiunction effectively in the coalition?

1. No

2. Yes

Q34. Has the coalition helped you learn more about childhood obesity?

Comment [JD36]: State the \% that agree

1. No
2. Yes

\section{COALITION MATURITY. READINESS. SUST AINABILITY}

Q35. Has your coalition been responsible for activities or programs that otherwise would not have occurred?

1. No

2. Yes

3. Don't know

Q36. Has your coalition brought benefit to your community?

Comment [JD37]: State the \% that agree

1. No

2. Yes

3. Don't know 
Q37. Please circle a number to show how much you agree or disagree with the following statements.

\begin{tabular}{|l|c|c|c|c|c|}
\hline & $\begin{array}{l}\text { Strongly } \\
\text { Disagree }\end{array}$ & Disagree & Agree & $\begin{array}{l}\text { Strongly } \\
\text { Agree }\end{array}$ & $\begin{array}{l}\text { Don't } \\
\text { Know }\end{array}$ \\
\hline $\begin{array}{l}\text { a) The coalition is making progress in } \\
\text { implementing the activities that have potential } \\
\text { to improve childhood obesity. }\end{array}$ & 1 & 2 & 3 & 4 & 5 \\
\hline $\begin{array}{l}\text { b) The coalition is improving health outcomes } \\
\text { for children who are at risk of obesity }\end{array}$ & 1 & 2 & 3 & 4 & 5 \\
\hline
\end{tabular}

Comment [JD38]: You can report Q37, Q38, and Q39 together to save space. State the \% that agree/strongly agree....or disagree/strongly disagree. E.G. " $71 \%$ of members agrec or strongly agrec that the sustainability plans once funding runs out

" $54 \%$ disagree that the coalition is essential to the improvement of pediatric obesity, that the coalition obesity, and that resources are being identified to support programmatic issues"

Q38. Please circle a number to show how much you agree or disagree with the following statements.

\begin{tabular}{|l|c|c|c|c|c|}
\hline & $\begin{array}{l}\text { Strongly } \\
\text { Disagree }\end{array}$ & Disagree & Agree & $\begin{array}{l}\text { Strongly } \\
\text { Agree }\end{array}$ & $\begin{array}{l}\text { Don't } \\
\text { Know }\end{array}$ \\
\hline $\begin{array}{l}\text { a) The coalition is making plans to continue } \\
\text { operating after current funding is terminated }\end{array}$ & 1 & 2 & 3 & 4 & 5 \\
\hline $\begin{array}{l}\text { b) The coalition has begun to find resources to } \\
\text { continue operating after current funding is } \\
\text { terminated }\end{array}$ & 1 & 2 & 3 & 4 & 5 \\
\hline $\begin{array}{l}\text { c) Resources are being identified to support the } \\
\text { systemic, programmatic changes implemented } \\
\text { through the work of the coalition }\end{array}$ & 1 & 2 & 3 & 4 & 5 \\
\hline
\end{tabular}

Q39. Please circle a number to show how much you agree or disagree with the following statements.

\begin{tabular}{|l|c|c|c|c|c|}
\hline & $\begin{array}{l}\text { Strongly } \\
\text { Disagree }\end{array}$ & Disagree & Agree & $\begin{array}{l}\text { Strongly } \\
\text { Agree }\end{array}$ & $\begin{array}{l}\text { Don't } \\
\text { Know }\end{array}$ \\
\hline $\begin{array}{l}\text { a) The coalition is essential to the improvement } \\
\text { of pediatric obesity }\end{array}$ & 1 & 2 & 3 & 4 & 5 \\
\hline $\begin{array}{l}\text { b) One or a small number of people or agencies } \\
\text { could make significant progress in pediatric } \\
\text { obesity without the coalition }\end{array}$ & 1 & 2 & 3 & 4 & 5 \\
\hline c) In general I am satisfied with the coalition & 1 & 2 & 3 & 4 & 5 \\
\hline
\end{tabular}

Q40. What issues should the coalition leadership and staff be paying more attention to?

Q41. Are there any critical events over the past year that have had an impact on the coalition? Please describe on the next page. 


\section{Annendix D- HealthKind's Fxecutive Summarv}

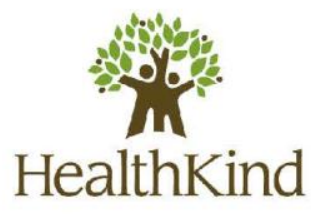

Sustaining Health

Strengthening Community.

\section{The Problem}

\section{Executive Summary}

Maternal and child health is of particular concern in the newly formed Republic of South Sudan. $28 \%$ of children under 5 years are severely or moderately undernourished and only $20 \%$ are immunized against measles. The maternal mortality rate is 2,054 deaths per 100,000 live births which is the highest in the world. Only $10.2 \%$ of all deliveries are attended by skilled birth attendants. Threats to maternal and child health care include protracted civil conflict and unrest, low human resource capacity, poor infrastructure, weak economy, high rates of illiteracy (especially women), limited opportunities for education, and socio-cultural beliefs and practices inimical to women and children. HIV/AIDS, malaria and other diseases are of great concern in this country and the World Health Organization (WHO) has asked the South Sudanese government to give special emphasis and priority to disease control interventions. The Ministry of Health's 20 year plan involves building a decentralized three-tier health care system in each of the Republic of South Sudan's 10 states. WHO recommends one health center per every 5,000 citizens. Current estimates of rural states, including Jonglei, show one health clinic per every 75,000 citizens and one hospital per 400,000 citizens.

\section{Our Mission}

To increase the availability of trained health workers in rural South Sudan and set in place a system for on-going support and continuing professional education of health workers on the ground leading to the establishment of a sustainable community health clinic in Jonglei, one of the most impoverished states in the Republic of South Sudan. Our project includes fundraising, training of community health care workers and staff, and construction of facilities. Furthermore, we intend to develop a model that can be replicated in other parts of South Sudan.

\section{Why Jonglei?}

Our project is specific to Jonglei because of our relationship with co-founder and refugee of this state, Kuier Atem Deng. Kuier was trained as a nurse in Sudan and has first-hand knowledge of the health care needs in this area of the Republic of South Sudan. 


\section{Our Project}

We are implementing a proven "train the trainer" model which allows us to provide prenatal care while facilitating medical training of people from the South Sudanese diaspora, IDPs, and in-country contacts to become in-country providers in Kuier's village, Kongor, Twic East County. Kongor is one of the many villages in the Republic of South Sudan where basic health care is minimal to non-existent. We envision a community-based health care worker training model that meets the specific needs of the local community while incorporating best practices in health care implementation services in other developing nations. We will also be building a secondary care facility which provides maternal and child health care services specifically (but not exclusively) and which will begin to build a foundation for health and wellness in Kongor. Although village specific, we are collaborating with others who are working on health care infrastructure in South Sudan, including existing NGOs and local resources.

\section{Background}

Democracy is in its infancy in the newly (as of July 9, 2011) independent Republic of South Sudan. In 2005, a Comprehensive Peace Agreement (CPA) was signed by the leadership in northern and southern Sudan which was an effort to put a halt to civil strife between the two parts of what, until July 9, 2011, was the largest country in Africa. The CPA served as a springboard for developing important national infrastructures for this diverse nation, including providing education and health care for their citizenry. South Sudan's population is multi-ethnic and multicultural, composed of Christians and hundreds of ethnic and tribal divisions and languages. Their health care needs are great but not insurmountable.As the leadership and citizens of this new country develop their democratic governing structure, the Ministry of Health will work to create a viable health care infrastructure. Indeed, the MOH believes this is a critical part of achieving the goals of the Comprehensive Peace Agreement. Those of us working at HealthKind will do our part to help sustain the health and strengthen the communities of citizens in the Republic of South Sudan.

For more information contact:

Rhonda R. Parmley, Program Director

rrparmley@healthkind.org

970-581-8827

$103133^{\text {rd }}$ St., Denver, CO 80205

Or

Kuier Atem, Republic of South Sudan Country Liaison

aad@healthkind.org

720-917-6915

Find us on the web at www.healthkind.org
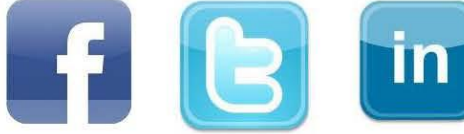

HealthKind is a U.S. 501 (c)(3) Charitable organization. 